\title{
Scalable $\alpha$-Arylation of Nitriles in Aqueous Micelles using Ultrasmall Pd Nanoparticles: Surprising Formation of Carbanions in Water
}

\author{
Manisha Bihani, ${ }^{\dagger}+$ Tharique N. Ansari, ${ }^{\dagger},+$ Lucie Finck, ${ }^{\dagger}$ Pranjal P. Bora, ${ }^{\dagger}$ Jacek B. Jasinski, \\ Bhavana Pavuluri, ${ }^{\dagger}$ David K. Leahy, ${ }^{*}$, Sachin Handa* ${ }^{* \dagger}$ \\ 'Department of Chemistry, University of Louisville, Louisville, Kentucky 40292, United States \\ 'Materials Characterization, Conn Center for Renewable Energy Research, University of Louisville, Louisville, KY, \\ 40292, USA \\ "Process Chemistry Development, Takeda Pharmaceuticals International, Cambridge, Massachusetts 02139, USA \\ *sachin.handa@,louisville.edu \\ *david.leahy@takeda.com
}

$\dagger$ These authors contributed equally.

\section{Supporting Information}

Contents

1. General experimental details

2. Synthesis and isolation of nanoparticles

3. Screening of nanoparticle precursors

4. Catalytic activity - isolated nanoparticles versus in-situ formed

5. Optimized procedure for catalytic couplings

6. Substrate scope

7. Multi-gram scale reaction

8. Oxygen trapping - synthesis of diaryl ketones

9. Carbanion trapping studies

10. One-pot $\alpha$-arylation and Suzuki coupling reaction

11. Detailed analysis of nanoparticles

12. Analysis of recycled nanoparticles

13. Catalytic activity of recycled nanoparticles

14. Analytical Data

15. Reference

16. NMR Spectra
Page

S1

S2

S3-S4

S5-S6

S7

S8

S9

S10

$\mathrm{S} 11-\mathrm{S} 12$

S13

S14-S17

S18-S19

S20

S21-S35

S35

S36-S78 


\section{GENERAL EXPERIMENTAL DETAILS}

All manipulations were carried out under inert atmosphere unless otherwise noted. Solvent molarity listed in reaction schemes is relative to the limiting reagent.

\subsection{Chemicals and Supply}

Chromatography. TLC plates (UV 254 indicator, aluminum backed, 175-225 $\mu \mathrm{m}$ thickness, standard grade silica gel, 230-400 mesh) was supplied by Merck; silica gel (60 A pore size, 230400 mesh) was purchased from Silicycle; sand was purchased from Fisher Chemical.

Solvents. Acetone, ethyl acetate, hexanes, methanol, dichloromethane, and HPLC-grade water were purchased from Fisher Chemical. NMR solvents were obtained from Cambridge Isotopes Laboratories; dry solvents were prepared using standard procedures; ${ }^{[1]}$ surfactant solutions were prepared in HPLC-grade water; PS-750-M was prepared as previously reported; ${ }^{[2]}$ poly(ethylene glycol) methyl ether 750 (mPEG-750-M) was supplied by Alfa-Aesar.

Reagents. All $\pi$-allyl palladium catalysts were obtained as a gift from Johnson-Matthey, $\mathrm{Pd}(\mathrm{OAc})_{2}$ was supplied by Chem-Impex Inc.; KOH was supplied by Fisher Chemical; Phenyl acetonitrile was supplied by Alfa-Aesar; Commercially available aryl bromides used were either supplied by Sigma-Aldrich or Combi-Blocks Inc. or Oakwood Chemicals, potassium phosphate was supplied by Fisher Chemical

1.2. General Instrumentation. All products were purified by flash chromatography using a Teledyne Isco CombiFlash Rf 150. GCMS data was obtained using a Thermo Scientific Trace 1300 Gas Chromatograph coupled with a Thermo Scientific ISQ-QD Single Quadrupole Mass Spectrometer. NMR spectra were recorded at $23{ }^{\circ} \mathrm{C}$ on Varian MR-400, Varian Unity INOVA 500, and Varian VNMRS 700 spectrometers (400, 500 and $700 \mathrm{MHz}$, respectively). Reported chemical shifts are referenced to residual solvent peaks. Infrared absorbance spectra were acquired on a FTIR Perkin Elmer Spectrum Two: UATR Two spectrometer using $1 \mathrm{~cm}^{-1}$ resolution. Highresolution mass analyses were obtained either using a 5975C Mass Selective Detector coupled with a 7890A Gas Chromatograph (Agilent Technologies) or orbit-trap. Melting points were determined using a Thomas Hoover melting point apparatus with samples in Kimble Kimex 51 capillaries $(1.5-1.8 \times 90 \mathrm{~mm})$. 


\section{SYNTHESIS AND ISOLATION OF NANOPARTICLES}

In an oven-dried $50 \mathrm{~mL}$ round-bottom flask containing a PTFE-coated stir bar, nanoparticle precursor 1 (400 mg, $0.589 \mathrm{mmol})$ and $\mathrm{K}_{3} \mathrm{PO}_{4}(124.8 \mathrm{mg}, 0.589 \mathrm{mmol})$ were transferred. The round-bottom flask was closed with a rubber septum, evacuated and then backfilled with argon. This process of evacuation and backfilling with argon was repeated for three times. Freshly argon purged $20.0 \mathrm{~mL} 3 \mathrm{wt} \%$ aq. PS-750-M was added to the reaction mixture. The reaction mixture was transferred to a pre-heated oil bath at $45^{\circ} \mathrm{C}$ for the next 30 minutes. The coloration of the suspension changed from off-milky white to light brown. After 30 minutes, reaction mixture was removed from the oil both and allowed to cool to rt. The obtained light brown suspension was used as the nanoparticle stock solution (SS-1). These nanoparticles were thoroughly characterized using ${ }^{31} \mathrm{P}$ NMR, HRTEM, and EDAX. The nanoparticles were stored at $\sim 5^{\circ} \mathrm{C}$ under argon atmosphere. These nanoparticles were stable for at least four weeks.
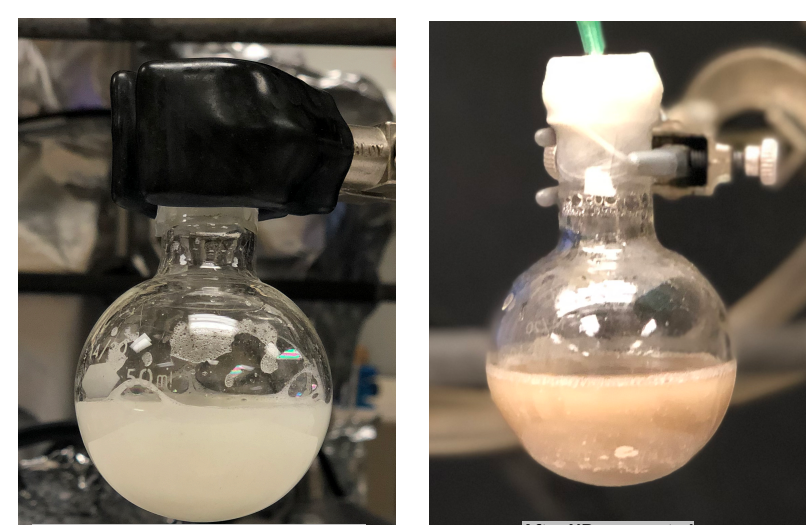

Figure S1. Nanoparticles synthesis: Synthesis at 0 minute (left) and after 30 minutes (right). 


\section{SCREENING OF NANOPARTICLE PRECURSORS}

Table S1. Screening of nanoparticle precursors

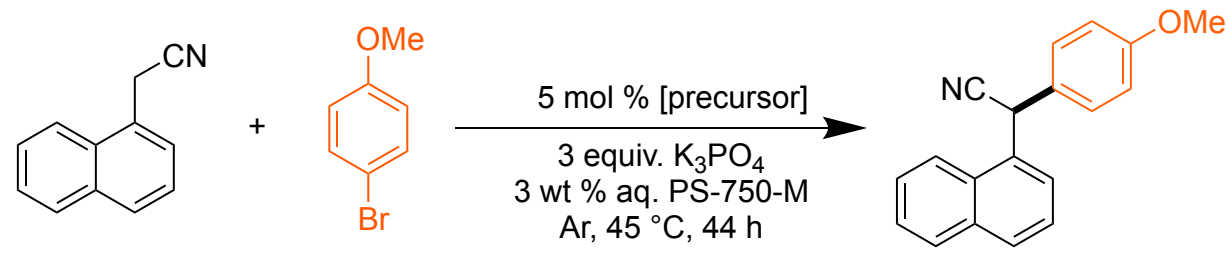

2a

2

10

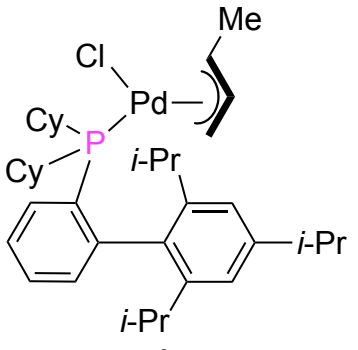

1

XPhosPd(crotyl)Cl

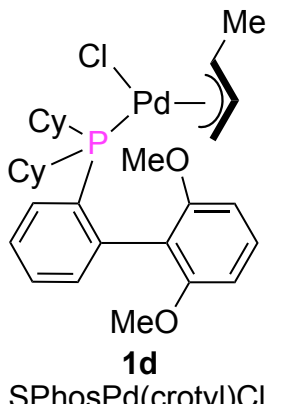

SPhosPd(crotyl)Cl

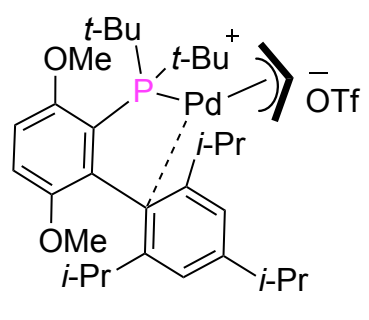

$1 a$

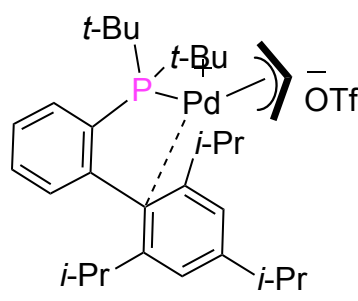

$1 \mathrm{~b}$

[t-BuXPhosPd(allyl)]OTf

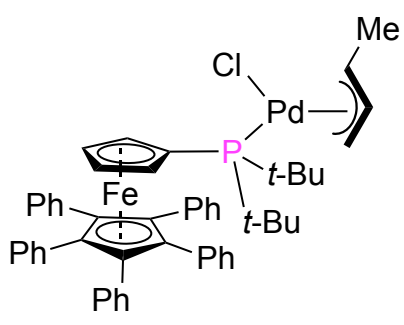

1c

QPhosPd(crotyl)Cl

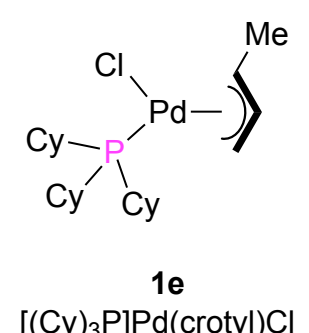

$\left[(\mathrm{Cy})_{3} \mathrm{P}\right] \mathrm{Pd}($ crotyl $) \mathrm{Cl}$

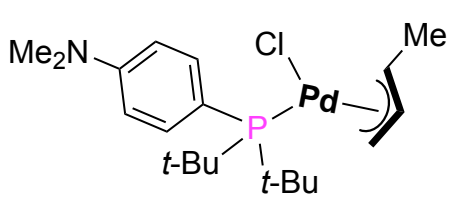

$1 f$ AmPhosPd(crotyl)Cl<smiles>CC1(C)c2cccc3c2OC2C(=CC=CC32)P[Pb](C=CCCl)P1c1ccccc1</smiles>

$1 \mathrm{~g}$

[XantPhosPd(allyl)]Cl 


\begin{tabular}{ccc}
\hline entry & nanoparticle precursor & $\mathbf{1 0}(\%)^{*}$ \\
\hline 1 & none & n.d \\
3 & $\mathbf{1}$ & $\mathbf{9 9}$ \\
3 & $\mathbf{1}$ & $99^{* *}$ \\
3 & $\mathrm{Pd}_{(\mathrm{OAc})}:$ XPhos $(1: 1.5)$ & 15 \\
4 & $\mathrm{PdCl}_{2}:$ XPhos $(1: 1.5)$ & 17 \\
5 & 4 mol $\% \mathbf{1}$ & 99 \\
6 & 3 mol $\% \mathbf{1}$ & 98 \\
7 & 2 mol $\% \mathbf{1}$ & 95 \\
8 & $\mathbf{1 a}$ & traces \\
9 & $\mathbf{1 b}$ & 30 \\
10 & $\mathbf{1 c}$ & 70 \\
11 & $\mathbf{1 d}$ & 96 \\
12 & $\mathbf{1 e}$ & traces \\
13 & $\mathbf{1 f}$ & 60 \\
14 & $\mathbf{1 g}$ & traces
\end{tabular}

Conditions: 2a (0.25 mmol), 2 (0.75 mmol), nanoparticle precursor $(5 \mathrm{~mol} \%), \mathrm{K}_{3} \mathrm{PO}_{4}(0.75 \mathrm{mmol}), 0.5 \mathrm{~mL} 3$ wt $\%$ aq. PS-750-M, Ar, $45{ }^{\circ} \mathrm{C}, 44 \mathrm{~h} .{ }^{* *} \mathrm{KOH}(0.75 \mathrm{mmol})$ was used instead of $\mathrm{K}_{3} \mathrm{PO}_{4}$; ${ }^{*}$ conversions based on GCMS. 


\section{CATALYTIC ACTIVITY - ISOLATED NANOPARTICLES VERSUS IN-SITU FORMED}

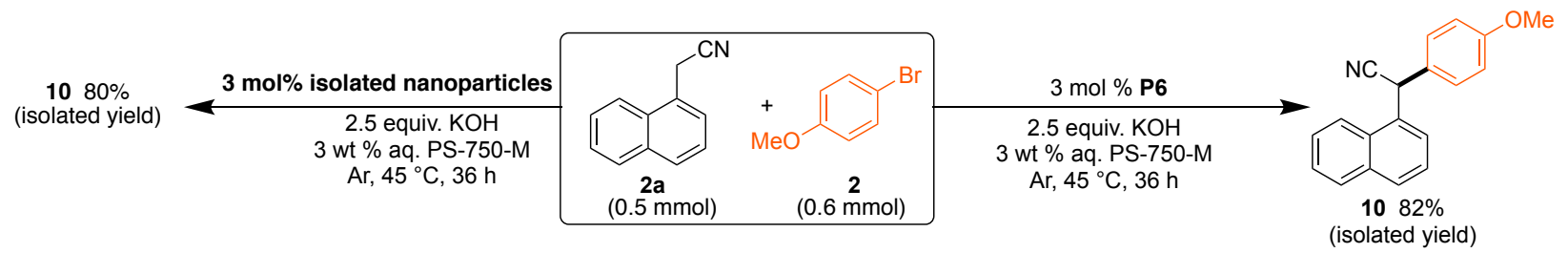

Scheme S1. Catalytic activity - isolated nanoparticles versus in-situ formed

4.1. Reaction with the isolated nanoparticles. Naphthylacetonitrile $\mathbf{2 a}(83.5 \mathrm{mg}, 0.5 \mathrm{mmol})$ was added into a $4 \mathrm{~mL}$ oven-dried reaction vial containing PTFE-coated stirrer bar. The reaction vial was evacuated and backfilled with argon for three times. Under the positive argon pressure, 2 (75.3 $\mu \mathrm{L}, 0.6 \mathrm{mmol})$ and $\mathrm{KOH}(70 \mathrm{mg}, 1.25 \mathrm{mmol})$ were sequentially added. The reaction vial was evacuated and backfilled with argon. $0.5 \mathrm{~mL}$ stock solution (SS-1) containing nanoparticle in aq. PS-750-M was added to the mixture. Finally, $0.5 \mathrm{~mL}$ of $3 \mathrm{wt} \%$ aq. PS-750-M was added to the reaction mixture. Septum was wrapped with PTFE tape and black electrical tape. The reaction mixture was stirred at $45^{\circ} \mathrm{C}$. After complete consumption of starting material as indicated by TLC, the reaction mixture was allowed to cool to $\mathrm{rt}$. EtOAc $(1.0 \mathrm{~mL})$ was added to the reaction mixture and stirred for a minute at rt. Stirring was stopped and organic layer was allowed to separate. The organic layer was separated from the aqueous layer using syringe. This cycle was repeated for an additional cycle. Combined organic layers were dried over anhydrous sodium sulfate. Volatiles were removed under reduced pressure to obtain crude product. Crude product was purified by flash chromatography over silica gel using EtOAc/hexanes as eluent $R_{\mathrm{f}} 0.25$ (1:9, EtOAc/hexanes). Pure product was obtained as viscous oil, yield $109.2 \mathrm{mg}(80 \%)$. The same reaction yield was obtained when catalytic reaction on $0.5 \mathrm{mmol}$ scale was ran using aged (four weeks) catalyst.

4.2. Reaction with in-situ formed nanoparticles. In a $4.0 \mathrm{~mL}$ flame-dried microwave vial containing a PTFE-coated magnetic stir bar, 1 (10 mg, $0.015 \mathrm{mmol})$ and $\mathrm{KOH}(1 \mathrm{mg})$ were added. $1 \mathrm{~mL}$ aqueous solution of $3 \mathrm{wt} \%$ PS-750-M was added to the reaction mixture and mixture was stirred under argon atmosphere at $45^{\circ} \mathrm{C}$ for 20 minutes. Under positive argon pressure, $2 \mathrm{a}$ (83.5 $\mathrm{mg}, 0.5 \mathrm{mmol}), 2(75.3 \mu \mathrm{L}, 0.6 \mathrm{mmol})$, and $\mathrm{KOH}(70 \mathrm{mg}, 1.25 \mathrm{mmol})$ were sequentially added. Septum was closed and wrapped with PTFE tape and black electrical tape. The reaction mixture was stirred continuously at $45{ }^{\circ} \mathrm{C}$. After complete consumption of starting material as monitored by TLC, the reaction mixture was allowed to cool to rt. EtOAc $(1.0 \mathrm{~mL})$ was added to the reaction mixture and the mixture was stirred for a minute at rt. Stirring was stopped and the organic layer was allowed to separate. The organic layer was withdrawn and this cycle was repeated for an 
additional cycle. Combined organic layers were dried over anhydrous sodium sulfate. Volatiles were removed under reduced pressure and the crude product was purified by flash chromatography over silica gel using EtOAc/hexanes as eluent $R_{\mathrm{f}} 0.25$ (1:9, EtOAc/hexanes). The pure product was obtained as viscous oil, yield $113 \mathrm{mg}(82 \%)$. 


\section{OPTIMIZED PROCEDURE FOR CATALYTIC COUPLINGS}

5.1. Reaction with the isolated nanoparticles. Under positive argon pressure, arylacetonitrile (0.5 mmol), hetero/aryl bromide $(0.6 \mathrm{mmol})$, and $\mathrm{KOH}(70 \mathrm{mg}, 1.25 \mathrm{mmol})$ were sequentially added into a $4 \mathrm{~mL}$ oven-dried reaction vial containing PTFE-coated stirrer bar. The reaction vial was evacuated and backfilled with argon for three times. An aqueous solution $(0.5 \mathrm{~mL})$ containing nanoparticles and PS-750-M from the stock solution (SS-1) was added to the reaction mixture. 0.5 $\mathrm{mL}$ of $3 \mathrm{wt} \%$ aq. PS-750-M was added to the mixture. The septum was wrapped with PTFE tape and black electrical tape. The reaction mixture was stirred at $45^{\circ} \mathrm{C}$. After complete consumption of starting material as monitored by TLC, reaction mixture was allowed to cool to rt. EtOAc (1.0 $\mathrm{mL}$ ) was added to the reaction mixture and stirred for a minute at rt. Stirring was stopped and organic layer was allowed to separate. An organic layer was separated from the aqueous layer with pipette. This cycle was repeated for an additional time. Combined organic layers were dried over anhydrous sodium sulfate. Volatiles were removed under reduced pressure to obtain the crude product. If needed crude product was purified by flash chromatography over the silica gel using ethyl acetate/hexanes as eluent.

5.2. Reaction with in-situ formed catalyst. In a $4.0 \mathrm{~mL}$ flame-dried microwave vial containing a PTFE-coated magnetic stir bar, $1(10 \mathrm{mg}, 0.015 \mathrm{mmol})$, arylacetonitrile $(0.5 \mathrm{mmol})$, aryl bromide (0.6 mmol), and $\mathrm{KOH}(70 \mathrm{mg}, 1.25 \mathrm{mmol})$ were sequentially added under argon atmosphere. 1 $\mathrm{mL}$ aqueous solution of $3 \mathrm{wt} \%$ PS-750-M was added to the reaction mixture. Septum was closed and wrapped with PTFE tape and black electrical tape. Mixture was evacuated and backfilled with argon. Reaction mixture was stirred under argon atmosphere at $45^{\circ} \mathrm{C}$. After complete consumption of starting material as monitored by TLC, reaction mixture was allowed to cool to rt. EtOAc (1.0 $\mathrm{mL}$ ) was added to the reaction mixture and the mixture was stirred for a minute at rt. Stirring was stopped and the organic layer was allowed to separate. The organic layer was withdrawn and this cycle was repeated for an additional cycle. Combined organic layers were dried over anhydrous sodium sulfate. Volatiles were removed under reduced pressure and the crude product was purified by flash chromatography over silica gel using EtOAc/hexanes as eluent. 


\section{SUBSTRATE SCOPE}

Table S2. Substrate scope for the $\alpha$-arylation of Nitriles

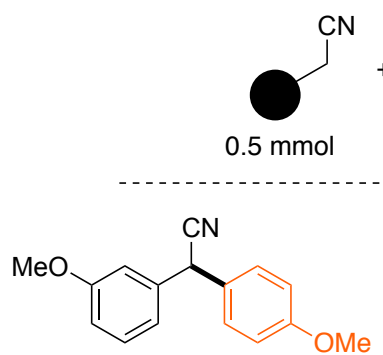

$411 \mathrm{~h}, 87 \%$

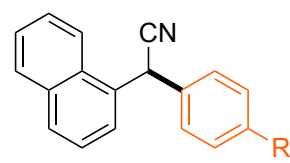

$10 \mathrm{R}=\mathrm{OMe} ; 36 \mathrm{~h}, 82 \%$

$11 \mathrm{R}=\mathrm{Me} ; \quad 30 \mathrm{~h}, 84 \%$

$12 \mathrm{R}=n-\mathrm{Bu} ; 40 \mathrm{~h}, 65 \%$

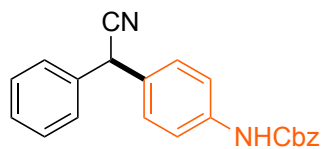

$2024 \mathrm{~h}, 65 \%$<smiles>N#CC(c1ccc(Cl)cc1)c1ccc2c(c1)Cc1ccccc1-2</smiles>

$2648 \mathrm{~h}, 88 \%$

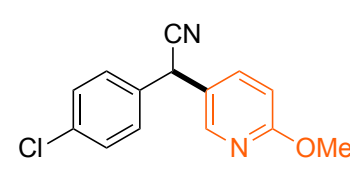

712 h, $90 \%$

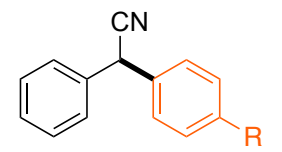

$13 \mathrm{R}=\mathrm{H} ; \quad 17 \mathrm{~h}, 84 \%$

$14 \mathrm{R}=\mathrm{OMe} ; 12 \mathrm{~h}, 91 \%$

$15 \mathrm{R}=\mathrm{Cl} ; \quad 41 \mathrm{~h}, 77 \%$

$16 \mathrm{R}=\mathrm{CF}_{3} \quad 24 \mathrm{~h}, 66 \%$

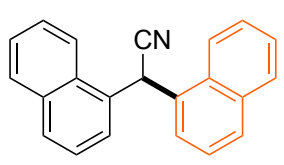

$821 \mathrm{~h}, 77 \%$

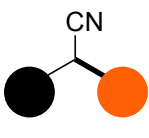<smiles>Cc1cc(C(C#N)c2ccc(Cl)cc2)cc([N+](=O)[O-])c1</smiles>

$920 \mathrm{~h}, 86 \%$<smiles>[R]c1ccc([C@H](C#N)c2cccc(OC)c2)cc1</smiles>

$17 \mathrm{R}=\mathrm{H} ; \quad 14 \mathrm{~h}, 87 \%$

$18 \mathrm{R}=\mathrm{Cl} ; \quad 41 \mathrm{~h}, 78 \%$

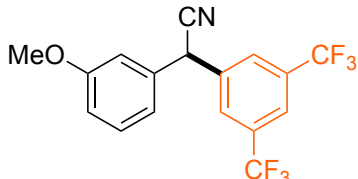

$1941 \mathrm{~h}, 78 \%$<smiles>[X]#[N+]c1ccc(C(C#N)c2ccc3c(c2)OCO3)cc1</smiles>

2128 h, $76 \%$

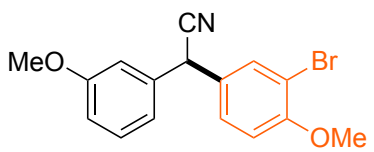

$2217 \mathrm{~h}, 72 \%$ **

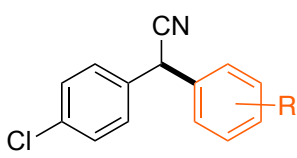

$23 \mathrm{R}=3-\mathrm{Me} ; 18 \mathrm{~h}, 91 \%$ $24 \mathrm{R}=4-\mathrm{OMe} ; 10 \mathrm{~h}, 92 \%$ $25 \mathrm{R}=4-\mathrm{Ph} ; \quad 14 \mathrm{~h}, 77 \%$<smiles>N#CC(c1ccc(Cl)cc1)c1c2ccccc2cc2ccccc12</smiles>

2740 h, $85 \%$

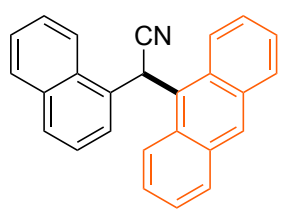

2848 h, $79 \%$

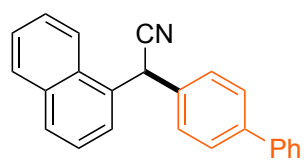

2940 h, 85\%<smiles>COc1ccc([C@H](C#N)c2ccc(Oc3ccccc3)cc2)cc1</smiles>

$3018 \mathrm{~h}, 82 \%$ $3136 \mathrm{~h}, 80 \%$

3214 h, $80 \%$<smiles>N#CC(c1ccc(-c2ccccc2)cc1)c1nc(-c2ccccc2)cs1</smiles>

$3424 \mathrm{~h}, 52 \%$<smiles>N#CC(c1ccc(Cl)cc1)c1ccc(CN2CCC3c4ccccc4NC3C2)cc1</smiles>

3528 h, $80 \%$<smiles>COc1cccc(C(C#N)c2ccc(Cn3cc(-c4ccccc4)nn3)cc2)c1</smiles>

$3630 \mathrm{~h}, 65 \%$<smiles>N#CC(c1ccc(Cl)cc1)c1ccc2c(ccn2Cc2ccccc2)c1</smiles>

3720 h, $74 \%$<smiles>CC(C)CCCC(C)C1CCC2C3CC=C4CC(n5cc(-c6ccc([C@H](C#N)c7ccc(Cl)cc7)cc6)nn5)CCC4(C)C3CCC12C</smiles>

3832 h, $41 \%$

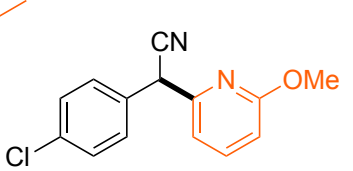

$3912 \mathrm{~h}, 80 \%$

Conditions: aryl acetonitrile $(0.5 \mathrm{mmol})$, aryl bromide $(0.6 \mathrm{mmol}), \mathbf{1}(3 \mathrm{~mol} \%), \mathrm{KOH}(1.25 \mathrm{mmol}), 1 \mathrm{~mL} 3 \mathrm{wt}$ $\%$ aq. PS-750-M, argon, $45^{\circ} \mathrm{C}$; unless otherwise noted, yields are isolated. $* *$ Aryl iodide was used as coupling partner. 


\section{MULTI-GRAM SCALE REACTION}

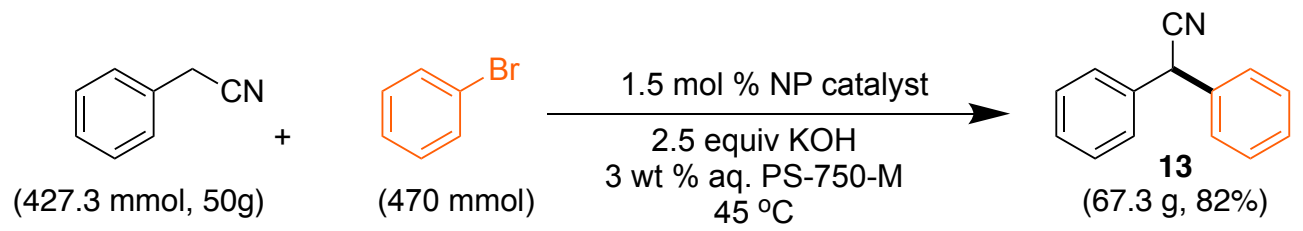

Scheme S2. Scalability of the protocol $-\alpha$-arylation of benzonitrile

In a $2 \mathrm{~L}$ flame dried round bottom flask equipped with septum and magnetic stirrer bar, 1 (4.35g, $6.41 \mathrm{mmol}$ ) was added. The round-bottom flask was closed with a rubber septum and the set-up was evacuated and backfilled with argon for three times. Under the positive pressure of argon, phenylacetonitrile (50.0 g, $427.3 \mathrm{mmol})$, bromobenzne (73.8 g, $470 \mathrm{mmol})$, and $\mathrm{KOH}(59.8 \mathrm{~g}$, $1068.25 \mathrm{mmol}$ ) were sequentially added. Approximately $860 \mathrm{~mL}$ of $3 \mathrm{wt} \%$ aq. PS-750-M was added to the reaction mixture under argon atmosphere. The septum was wrapped with PTFE tape and black electrical tape. The reaction mixture was stirred at $45^{\circ} \mathrm{C}$ for $38 \mathrm{~h}$.

After reaction completion as indicated by TLC and GCMS analysis, mixture was cooled to rt. The reaction mixture was transferred to a separatory funnel. Without the addition of any organic solvent, two layers were separated. The bottom layer (brown color) was separated and transferred to an Erlenmeyer flask. This dark grey oil turns to solid within 5 minutes. The dark solid was dissolved in ethyl acetate $(\sim 70 \mathrm{~mL})$ and passed through a charcoal / celite pad. Volatiles were removed from the filtrate to obtain yellow solid, which was recrystallized using cyclohexane/pentane. The pure product was obtained as an off-white solid $\left(R_{\mathrm{f}} 0.3,1: 19\right.$ EtOAc: Hexanes); yield $67.3 \mathrm{~g},(82 \%)$. 


\section{OXYGEN TRAPPING - SYNTHESIS OF DIARYL KETONES}

Table S3. Substrate scope for the diaryl ketone synthesis
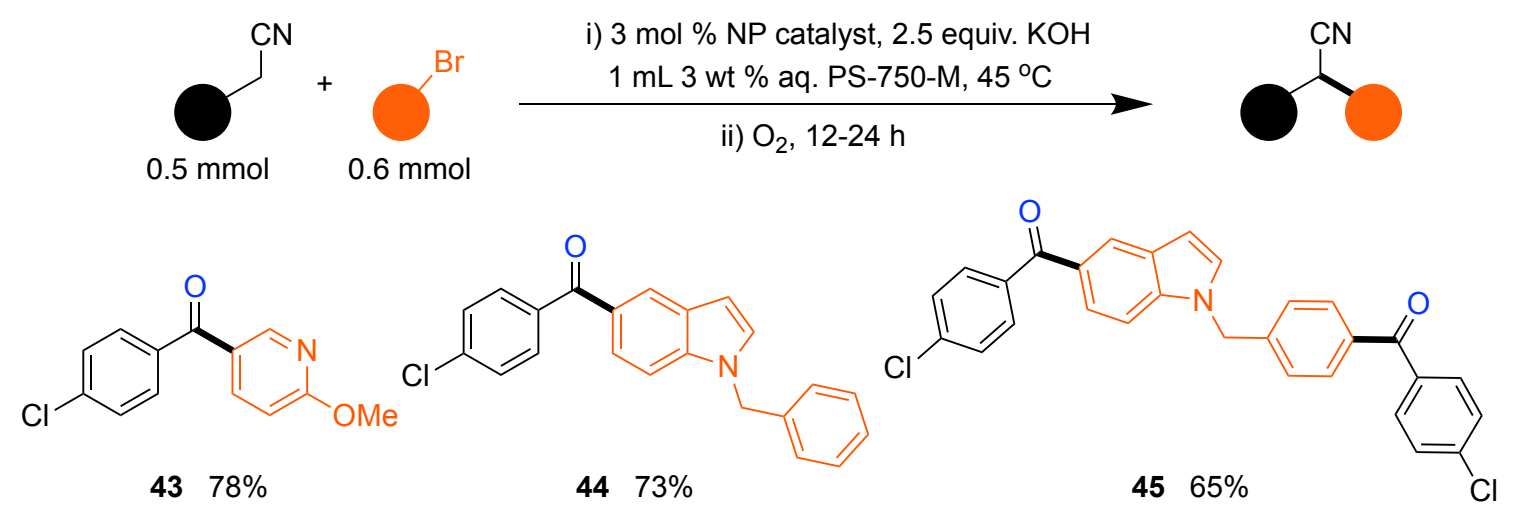

In a $4.0 \mathrm{~mL}$ flame-dried microwave vial containing a PTFE-coated magnetic stir bar, 1 (10 mg, $0.015 \mathrm{mmol})$, and $\mathrm{KOH}(1 \mathrm{mg})$ were added and mixture was stirred at $45^{\circ} \mathrm{C}$ for 20 minutes under argon atmosphere. Under the positive argon pressure, arylacetonitrile $(0.5 \mathrm{mmol})$, aryl/heteroaryl bromide $(0.6 \mathrm{mmol})$, and $\mathrm{KOH}(1.25 \mathrm{mmol})$ were sequentially added. $1.0 \mathrm{~mL} 3 \mathrm{wt} \%$ aq. PS-750$\mathrm{M}$ was added to the reaction mixture under argon. The septum was wrapped with PTFE tape and black electrical tape. The reaction mixture was continued to stir at $45{ }^{\circ} \mathrm{C}$. After complete consumption of arylacetonitrile as monitored by TLC or GCMS, an oxygen balloon was placed on the top of the reaction vial and mixture was purged with molecular oxygen for 5 minutes. The reaction was continued to stir at $45{ }^{\circ} \mathrm{C}$ under oxygen atmosphere. After reaction completion as monitored by GCMS or TLC, reaction mixture was allowed to cool to rt. $1.0 \mathrm{~mL}$ ethyl acetate was added to the reaction mixture. The mixture was then gently stirred for 2 min at rt. Stirring was stopped and the organic layer was separated using a pipette or syringe. This extraction was repeated one an additional time. Combined organic layers were dried over anhydrous sodium sulfate and volatiles were evaporated under reduced pressure at room temperature to obtain the crude product. The crude product was further purified by flash chromatography over silica gel using hexanes/ethyl acetate as eluent. 


\section{CARBANION TRAPPING STUDIES}
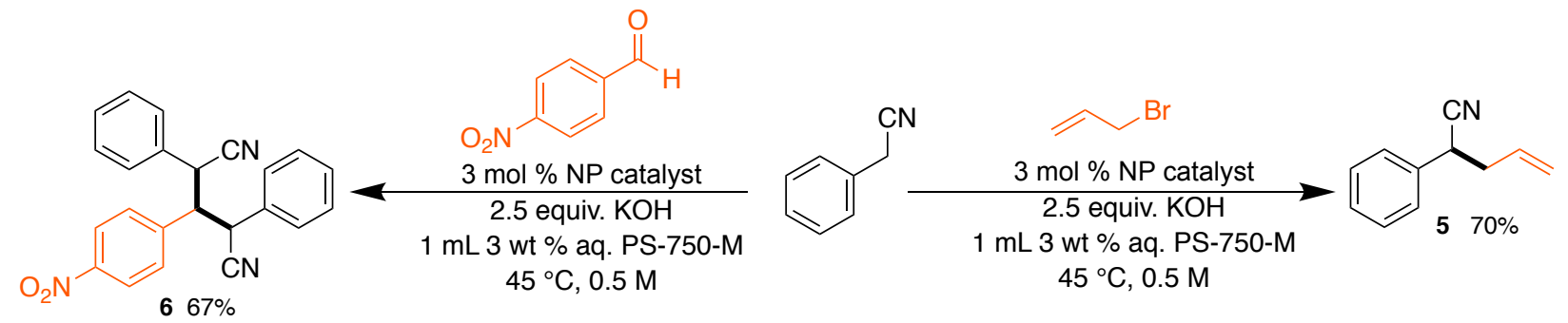

Scheme S3. Carbanion trapping studies - reaction of benzonitrile with allyl bromide and aldehyde

9.1 Reaction with p-nitrobenzaldehyde: $\mathrm{KOH}(35.0 \mathrm{mg}, 0.625 \mathrm{mmol})$, and nanoparticle precursor 1 ( $5 \mathrm{mg}, 0.0075 \mathrm{mmol}$ ) were added into the $4 \mathrm{~mL}$ oven-dried reaction vial containing PTFE-coated stirrer-bar. The reaction vial was closed with a rubber septum. The reaction mixture was evacuated and backfilled with argon for three times. $0.5 \mathrm{~mL} 3 \mathrm{wt} \%$ aq. PS-750-M was added to the mixture and mixture was heated at $45^{\circ} \mathrm{C}$ for 30 minutes. Phenylacetonitrile $(30 \mu \mathrm{L}, 0.27$ mmol) was added to the reaction mixture and it was stirred for 5 minutes at $45^{\circ} \mathrm{C}$. Reaction mixture was allowed to cool to rt. Septum was opened and $p$-nitrobenzaldehyde (30.2 $\mathrm{mg}, 0.2 \mathrm{mmol}$ ) was added to the mixture. Reaction vial was closed with a rubber septum. The reaction mixture was evacuated and backfilled with argon for three times. The vial was transferred to a pre-heated wellplate at $45^{\circ} \mathrm{C}$. After $17 \mathrm{~h}$, the mixture was cooled to room temperature. The septum was removed, and $1.0 \mathrm{~mL}$ EtOAc was added to the reaction mixture, which was then stirred for a minute at $\mathrm{rt}$. Stirring was stopped, and the organic layer was allowed to separate from the aqueous layer. An organic layer was removed with the help of a pipette. The extraction process was repeated for an additional time. Combined organic layers were dried over anhydrous sodium sulfate. Volatiles were removed under reduced pressure to obtain crude product, which was purified by flash chromatography over silica gel using EtOAc/hexanes as eluent $R_{\mathrm{f}} 0.33$ (1:4, EtOAc/hexanes). Pure product was obtained as a yellow solid, yield $49.5 \mathrm{mg}(67 \%)$.

9.2 Reaction with allylbromide: $\mathrm{KOH}(35.0 \mathrm{mg}, 0.625 \mathrm{mmol})$ and nanoparticle precursor $(\mathbf{1}, 5$ $\mathrm{mg}, 0.0075 \mathrm{mmol}$ ) was added into the $4 \mathrm{~mL}$ oven-dried reaction vial containing PTFE-coated stirrer-bar. Reaction vial was closed with a rubber septum. Reaction mixture was evacuated and backfilled with argon for three times. $0.5 \mathrm{~mL} 3 \mathrm{wt} \%$ aq. PS-750-M was added to the mixture and mixture was heated at $45{ }^{\circ} \mathrm{C}$ for 30 minutes. Later, phenylacetonitrile (30 $\mu \mathrm{L}, 0.27 \mathrm{mmol}$ ) was added. The mixture was stirred for 5 minutes at $45{ }^{\circ} \mathrm{C}$. Mixture was allowed to cool to rt. Allyl 
bromide ( $22 \mu \mathrm{L}, 0.25 \mathrm{mmol}$ ) was added and the reaction vial was transferred to a pre-heated wellplate at $45^{\circ} \mathrm{C}$. Reaction was stirred at $45^{\circ} \mathrm{C}$ for $17 \mathrm{~h}$. Reaction mixture was cooled to rt. Septum was removed and $1.0 \mathrm{~mL}$ EtOAc was added to the reaction mixture. Mixture stirred for a minute at rt. Stirring was stopped and organic layer was allowed to separate from the aqueous layer. An organic layer was removed with the help of a pipette. This extraction process was repeated for an additional time. Combined organic layers were dried over anhydrous sodium sulfate. Volatiles were removed under reduced pressure to obtain crude product. The crude product was purified by flash chromatography over silica gel using EtOAc/hexanes as eluent $R_{\mathrm{f}} 0.22$ (1:19, EtOAc/hexanes). The pure product was obtained as a viscous oil, yield $27.5 \mathrm{mg}(70 \%)$. 


\section{ONE-POT $\alpha$-ARYLATION AND SUZUKI-MIYAURA COUPLING}

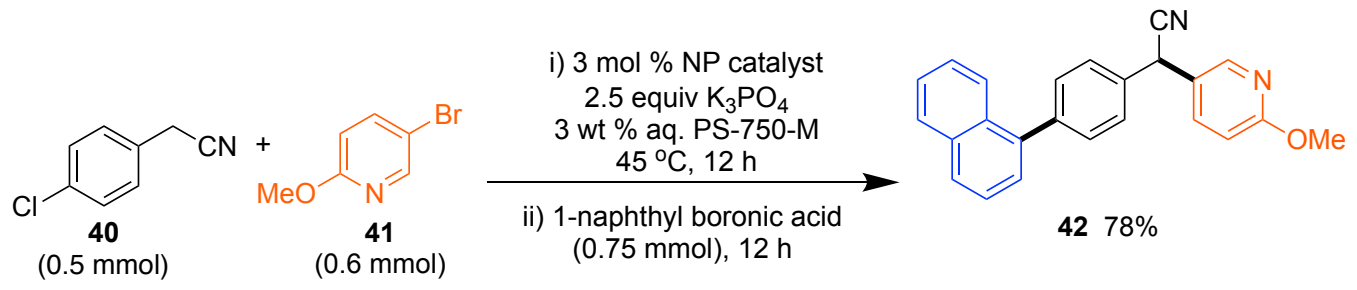

Scheme S4. One-pot reaction $-\alpha$-arylation followed by Suzuki Miyaura coupling

In a $4.0 \mathrm{~mL}$ flame-dried microwave vial containing a PTFE-coated magnetic stir bar, 1 (10 mg, $0.015 \mathrm{mmol}), \mathrm{K}_{3} \mathrm{PO}_{4}(2 \mathrm{mg})$, and $1.0 \mathrm{~mL}$ aq. $3 \mathrm{wt} \%$ PS-750-M were sequentially added and mixture was stirred at $45{ }^{\circ} \mathrm{C}$ for 20 minutes under argon atmosphere. Under the positive pressure of argon, 40 (75 mg, $0.5 \mathrm{mmol}), 41$ (113 mg, $0.6 \mathrm{mmol})$, and $\mathrm{K}_{3} \mathrm{PO}_{4}(265 \mathrm{mg}, 1.25 \mathrm{mmol})$ were sequentially added. The septum was wrapped with PTFE tape and black electrical tape. Reaction mixture was stirred at $45{ }^{\circ} \mathrm{C}$ for $12 \mathrm{~h}$ under argon atmosphere. After $12 \mathrm{~h}$, naphthyl boronic acid (212 mg, $0.75 \mathrm{mmol}$.) was added to the reaction mixture and mixture was stirred for $12 \mathrm{~h}$ at $60{ }^{\circ} \mathrm{C}$. After reaction completion as monitored by TLC or GCMS, $2.0 \mathrm{~mL}$ ethyl acetate was added to the reaction mixture. Reaction mixture was gently stirred for 2 min. Stirring was stopped and an organic layer was allowed to separate. An organic layer was separated using a pipette. This extraction was repeated using additional $1.0 \mathrm{~mL}$ EtOAc. Combined extracts were dried over anhydrous sodium sulfate and volatiles were evaporated under reduced pressure at room temperature to obtain crude product. Crude product was further purified by flash chromatography over silica gel using hexanes/ethyl acetate (1:4), $R_{\mathrm{f}} 0.24$ as eluent to get the product as white solid $140 \mathrm{mg},(78 \%)$. 


\section{DETALIED ANALYSIS OF NANOPARTICLES}

\subsection{Analysis by NMR spectroscopy}

(a) ${ }^{31}$ P NMR spectrum of nanoparticles. The nanoparticles suspended in $3 \mathrm{wt} \%$ aq. PS-750-M were prepared according to the procedure provided in section 2 (page- S2). $0.25 \mathrm{~mL}$ aliquot withdrawn from the nanoparticle stock solution (SS-1) was dissolved in 0.25 mL DMSO-d 6 and was analyzed with ${ }^{31} \mathrm{P}$ NMR spectroscopy using Varian Innova $400 \mathrm{MHz} \mathrm{NMR}$ spectrophotometer. (Note: The internal standard was prepared in a capillary tube by dissolving $\mathrm{PPh}_{3}$ in DMSO(d6), and tip of capillary tube was permanently sealed).

Table S4. Sample details for NMR experiments

\begin{tabular}{c|c}
\hline Sample ID & Constituents \\
\hline Sample-A & XPhos in 0.5 mL of DMSO-d 6 \\
Sample-B & $0.25 \mathrm{~mL} \mathrm{SS-1}+0.25 \mathrm{~mL} \mathrm{DMSO}-\mathrm{d}_{6}$ \\
\hline
\end{tabular}

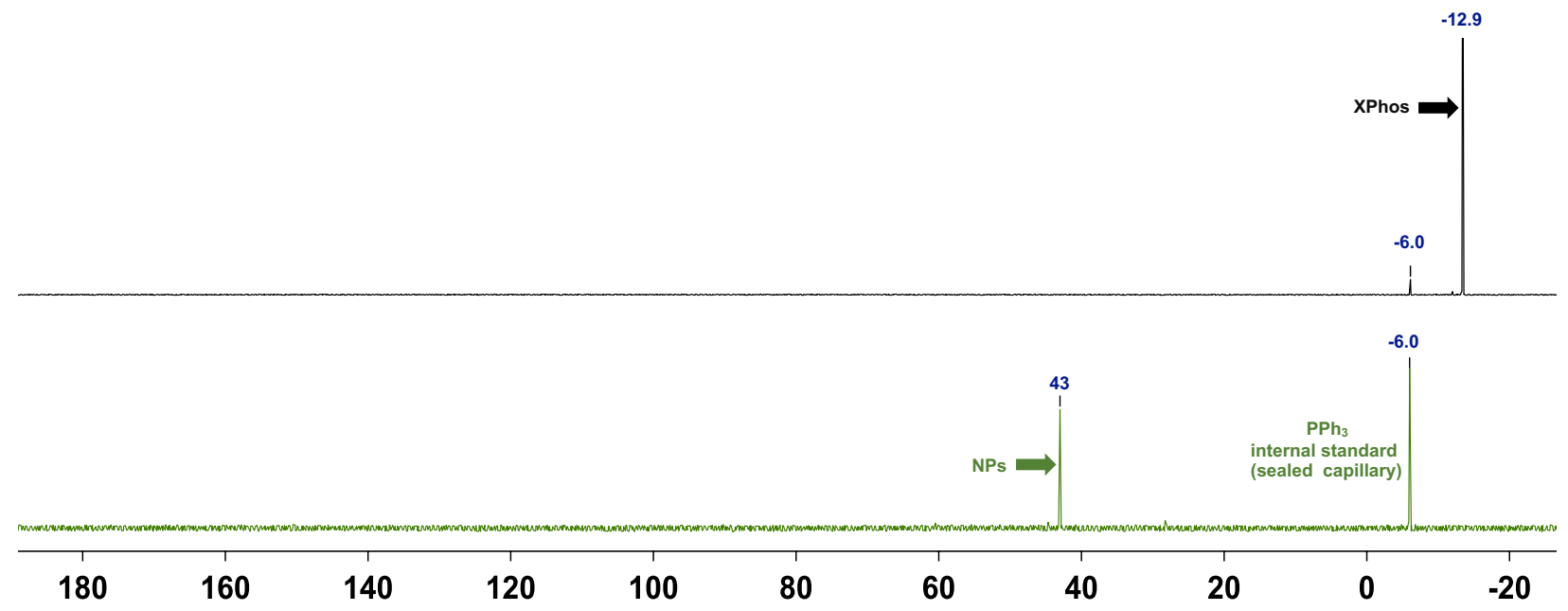

Figure S2. ${ }^{31} \mathrm{P}$ NMR spectra of NPs (bottom) compared to XPhos (top) using $\mathrm{PPh}_{3}$ as internal std.

(b) Reaction of nanoparticle with substrates. All samples (except- sample A in the Table on next page) were heated at $60{ }^{\circ} \mathrm{C}$ in $3 \mathrm{wt} \%$ aq. solution of PS-750-M (in $\left.\mathrm{D}_{2} \mathrm{O}\right)$ : THF $(\sim 1: 2)$ for 30 - 60 minutes. Approximately $0.4 \mathrm{~mL}$ aliquot from each sample (except-sample A) was transferred to NMR tube under inert atmosphere. All experiments were carried out in Varian Innova $400 \mathrm{MHz}$ NMR at $25^{\circ} \mathrm{C}$. DMSO $\left(\mathrm{d}_{6}\right)$ was used as co-solvent $(\sim 0.1-0.2 \mathrm{~mL})$ and $\mathrm{PPh}_{3}$ as internal standard 
were used in each experiment. (Note: The internal standard was prepared in a capillary tube by dissolving $\mathrm{PPh}_{3}$ in DMSO(d6), and the tip of capillary tube was permanently sealed)

Table S5. Sample details for NMR experiments

\begin{tabular}{|c|c|}
\hline Sample ID & Constituents \\
\hline Sample-A & Nanoparticles in $3 \mathrm{wt} \%$ PS-750-M in $\mathrm{D}_{2} \mathrm{O}$ \\
\hline Sample-B & $\begin{array}{l}1 \text { equiv NPs }+2 \mathrm{mg} \mathrm{KOH}+1 \mu \mathrm{L} \text { 4-bromoanisole }+0.25 \mathrm{~mL} 3 \mathrm{wt} \% \mathrm{PS}-750-\mathrm{M} \text { in } \mathrm{D}_{2} \mathrm{O}+ \\
\sim 0.5 \mathrm{~mL} \mathrm{THF}\end{array}$ \\
\hline Sample-C & $\begin{array}{l}1 \text { equiv NPs }+1 \mathrm{mg} \text { of } \mathrm{KOH}+\sim 1 \mu \mathrm{L} 3 \text {-methoxyacetonitrile }+\sim 1 \mathrm{~mL} 3 \mathrm{wt} \% \text { PS-750- } \\
\qquad \mathrm{M} \text { in } \mathrm{D}_{2} \mathrm{O}\end{array}$ \\
\hline Sample-D & $\begin{array}{c}1 \text { equiv NPs }+\sim 1 \mu \mathrm{L} \text { 4-bromoanisole }+\sim 1 \mu \mathrm{L} 3 \text {-methoxyacetonitrile }+0.25 \mathrm{~mL} 3 \\
\qquad \text { wt } \% \text { PS-750-M in } \mathrm{D}_{2} \mathrm{O}+\sim 0.5 \mathrm{~mL} \text { THF }\end{array}$ \\
\hline
\end{tabular}
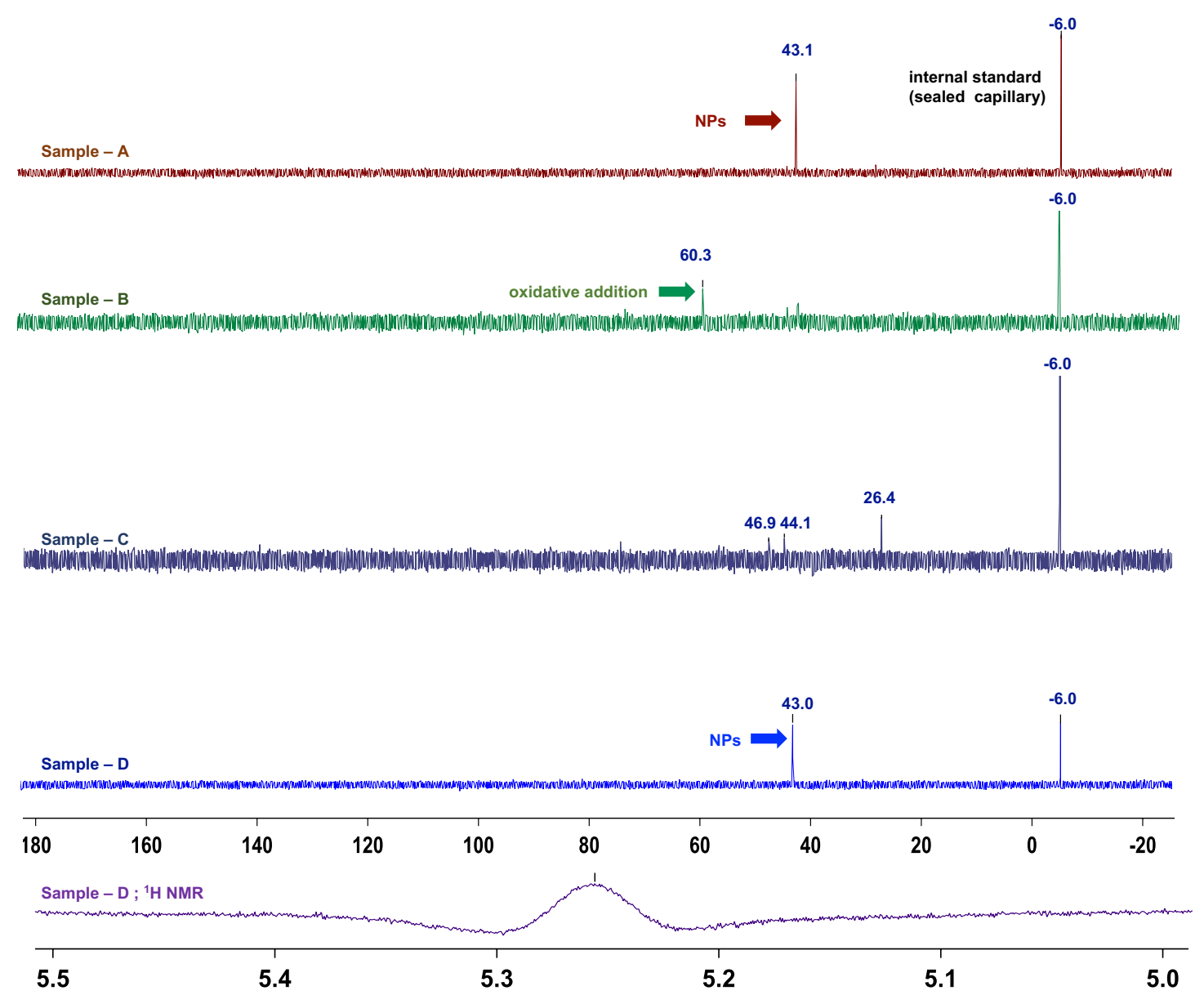

Figure S3. ${ }^{31} \mathrm{P}$ NMR investigation on substrate interaction with nanoparticles 
11.2 HRTEM analysis of the nanoparticles. The sample was prepared by diluting $0.1 \mathrm{~mL}$ of nanoparticle stock solution SS-1 with $0.4 \mathrm{~mL}$ of DI $\mathrm{H}_{2} \mathrm{O}$.

(HRTEM, STEM-HAADF, and EDX analysis were conducted using a $200 \mathrm{kV}$ field emission gun FEI Tecnai F20 microscope and specimens prepare by drop casting catalyst dispersions onto commercial copper grid-supported amorphous holey carbon films).
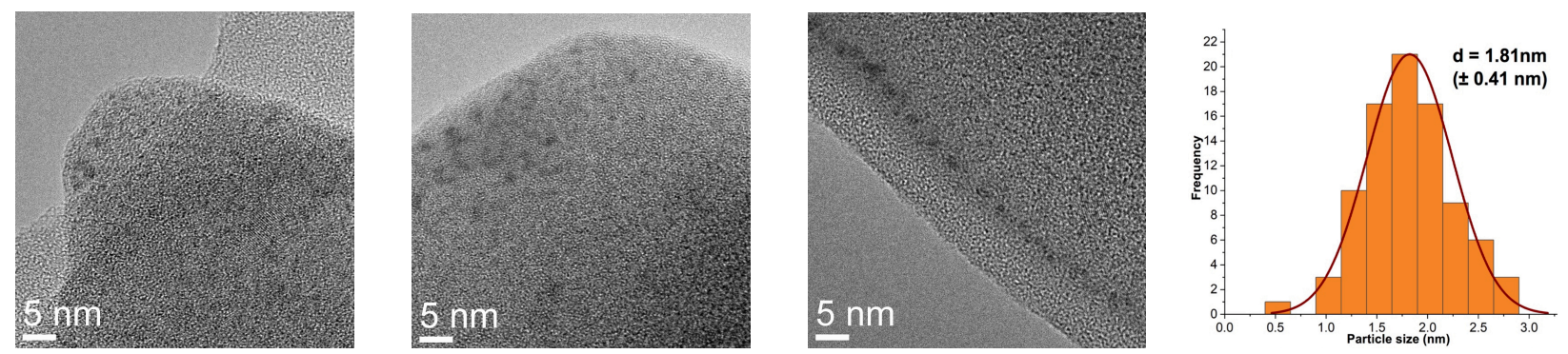

Figure S4. HRTEM of nanoparticles and histogram of particle size distribution

EDAX mapping was also done to ensure the uniform distribution of the catalyst.

\section{$\underline{\text { EDAX analysis of the catalyst }}$}

EDAX analysis and mapping confirmed the presence of phosphorus from XPhos, N from PS-750$\mathrm{M}$, palladium, and $\mathrm{Cl}$ ions from the precatalyst. Thus, these combined results evidenced the formation of ultrasmall Pd NPs. The relative atomic concentrations of $\mathrm{P}, \mathrm{Cl}$, and $\mathrm{Pd}$, estimated based on EDAX spectra are $40 \%, 28 \%$, and $32 \%$ respectively. The N-K peak had a too low intensity to be included in the quantification, and the concentration of $\mathrm{N}$ was estimated to be well below $1 \%$. On the other hand, the omission of $\mathrm{C}$ from the elemental quantification was due to the issue of the overlap between Pd M zeta and C K alpha. The Pd M zeta line is at $282 \mathrm{eV}$ while the $\mathrm{C} \mathrm{K}$ alpha is at $277 \mathrm{eV}$, giving a separation of $4 \mathrm{eV}$ only, which is significantly below the energy resolution of EDAX. 

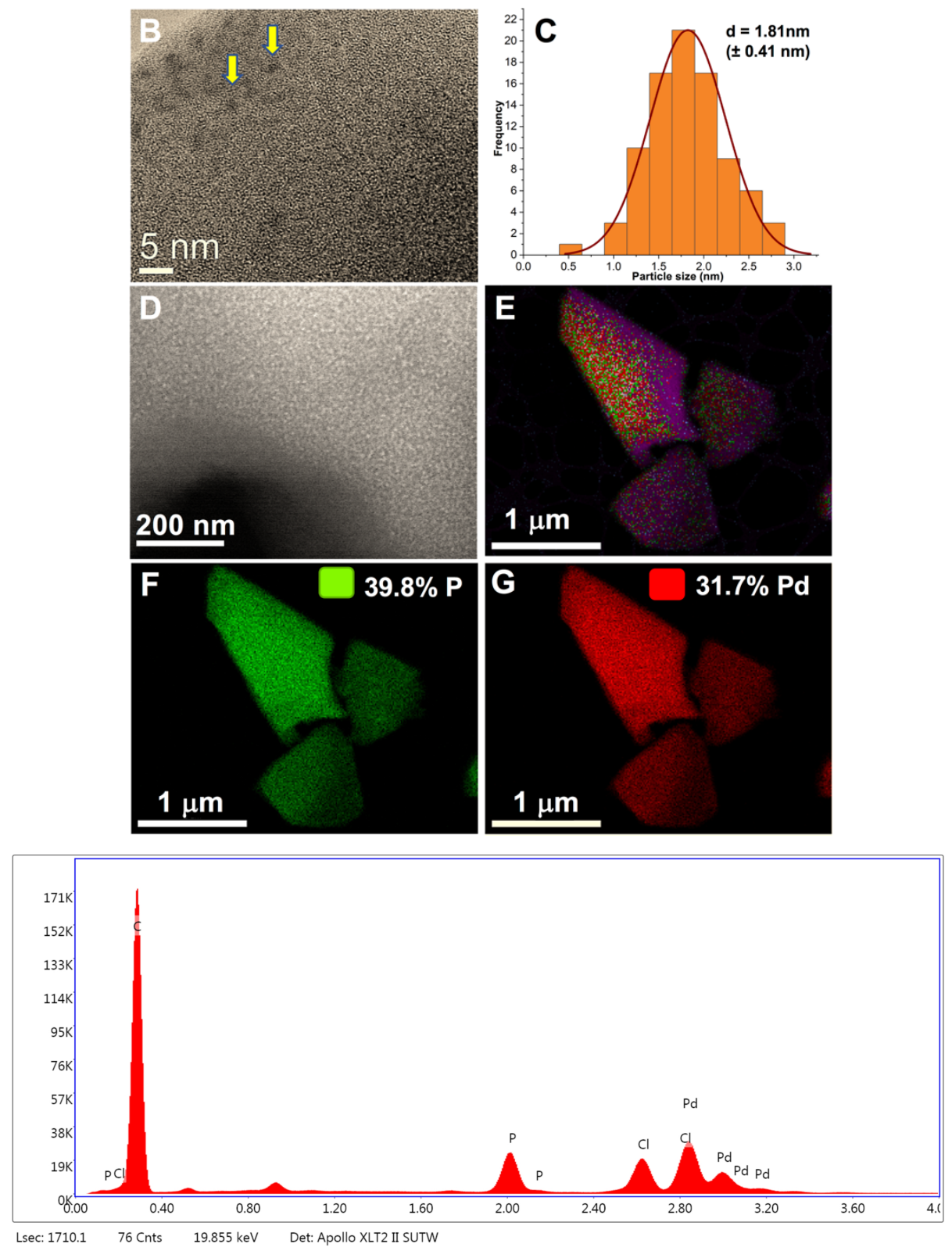

Figure S5. EDAX mapping of the nanoparticles.

Table S6. EDAX quantification of constituents

\section{eZAF Smart Quant Results}

\begin{tabular}{cccc}
\hline element & atomic $\%$ & net int. & error \% \\
\hline P K & 39.79 & 248.70 & 6.55 \\
ClK & 28.49 & 228.50 & 7.35 \\
PdL & 31.72 & 332.70 & 4.83 \\
\hline
\end{tabular}




\section{ANALYSIS OF RECYCLED NANOPARTICLES}

\section{$\underline{\text { Sample preparation - }}$}

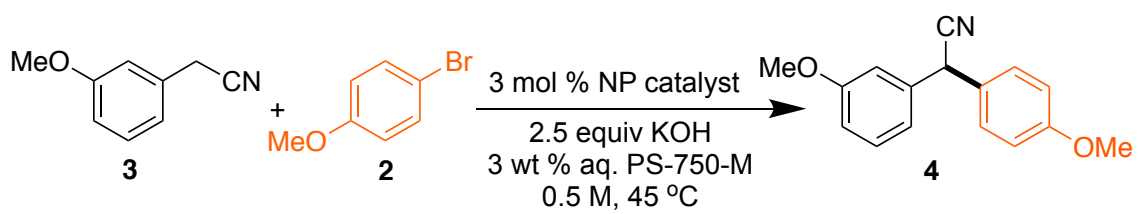

Scheme S5. Reaction for the preparation of the recycled nanoparticles

$\mathrm{KOH}$ (35 mg, $0.625 \mathrm{mmol}$ ) was added into a $4 \mathrm{~mL}$ oven-dried reaction vial containing PTFEcoated stirrer bar. The reaction vial was closed with a rubber septum, evacuated and backfilled with argon for three times. Later, arylacetonitrile $\mathbf{3}$ (73.5 $\mathrm{mg}, 0.5 \mathrm{mmol})$, 4-bromoanisole 2 (112.2 $\mathrm{mg}, 0.6 \mathrm{mmol})$, aqueous solution $(0.5 \mathrm{~mL})$ containing nanoparticles and PS-750-M from the stock solution (SS-1) and $0.5 \mathrm{~mL}$ of $3 \mathrm{wt} \%$ aq. PS-750-M was added to the mixture. The septum was wrapped with PTFE tape and black electrical tape. The reaction mixture was stirred at $45{ }^{\circ} \mathrm{C}$ for $11 \mathrm{~h}$. Then the reaction mixture was allowed to cool to rt. EtOAc $(1.0 \mathrm{~mL})$ was added to the reaction mixture without opening the septum and stirred for a minute at rt. Stirring was stopped and organic layer was allowed to separate. The organic layer was removed using a syringe and this cycle was repeated for an additional time. Combined organic layers were dried over anhydrous sodium sulfate. Volatiles were removed under reduced pressure to obtain the crude product. The crude product was purified by flash chromatography over the silica gel using ethyl acetate/hexanes as eluent $110 \mathrm{mg}(87 \%)$ and $R_{\mathrm{f}} 0.38(1: 9$, EtOAc/hexanes). $0.1 \mathrm{~mL}$ aliquot from the remaining aqueous medium was taken out and diluted with $0.4 \mathrm{~mL}$ of HPLC grade water. This mixture as analyzed using EDAX and HRTEM.
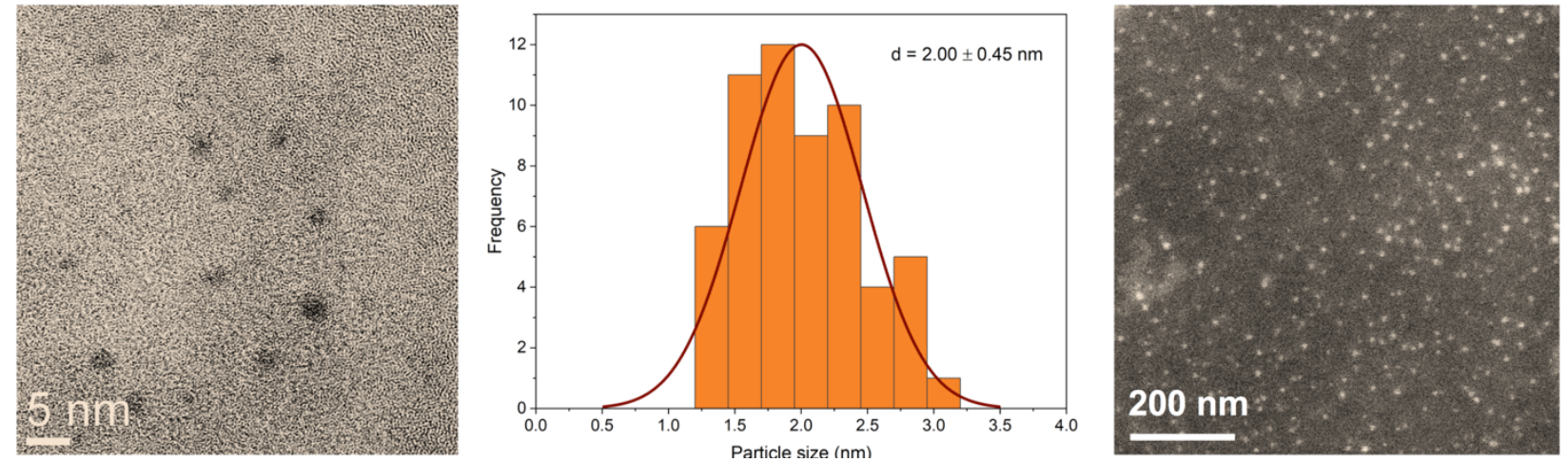

Figure S6. HRTEM and dark field SEM analysis of recycled nanoparticles. 
EDAX analysis: EDAX analysis and mapping confirmed the presence of phosphorus from XPhos, $\mathrm{N}$ from PS-750-M, palladium, and $\mathrm{Cl}$ ions from the precatalyst. Thus, these combined results evidenced the formation of ultrasmall Pd NPs without significant leaching of phosphine ligand. The relative atomic concentrations of $\mathrm{P}, \mathrm{Cl}$, and $\mathrm{Pd}$, estimated based on EDAX spectra are $40 \%, 27 \%$, and $33 \%$ respectively. The $\mathrm{N}-\mathrm{K}$ peak had a too low intensity to be included in the quantification, and the concentration of $\mathrm{N}$ was estimated to be well below $1 \%$. On the other hand, the omission of $\mathrm{C}$ from the elemental quantification was due to the issue of the overlap between $\mathrm{Pd} \mathrm{M}$ zeta and $\mathrm{C} \mathrm{K}$ alpha. The Pd M zeta line is at $282 \mathrm{eV}$ while the $\mathrm{C} \mathrm{K}$ alpha is at $277 \mathrm{eV}$, giving a separation of $4 \mathrm{eV}$ only, which is significantly below the energy resolution of EDAX.

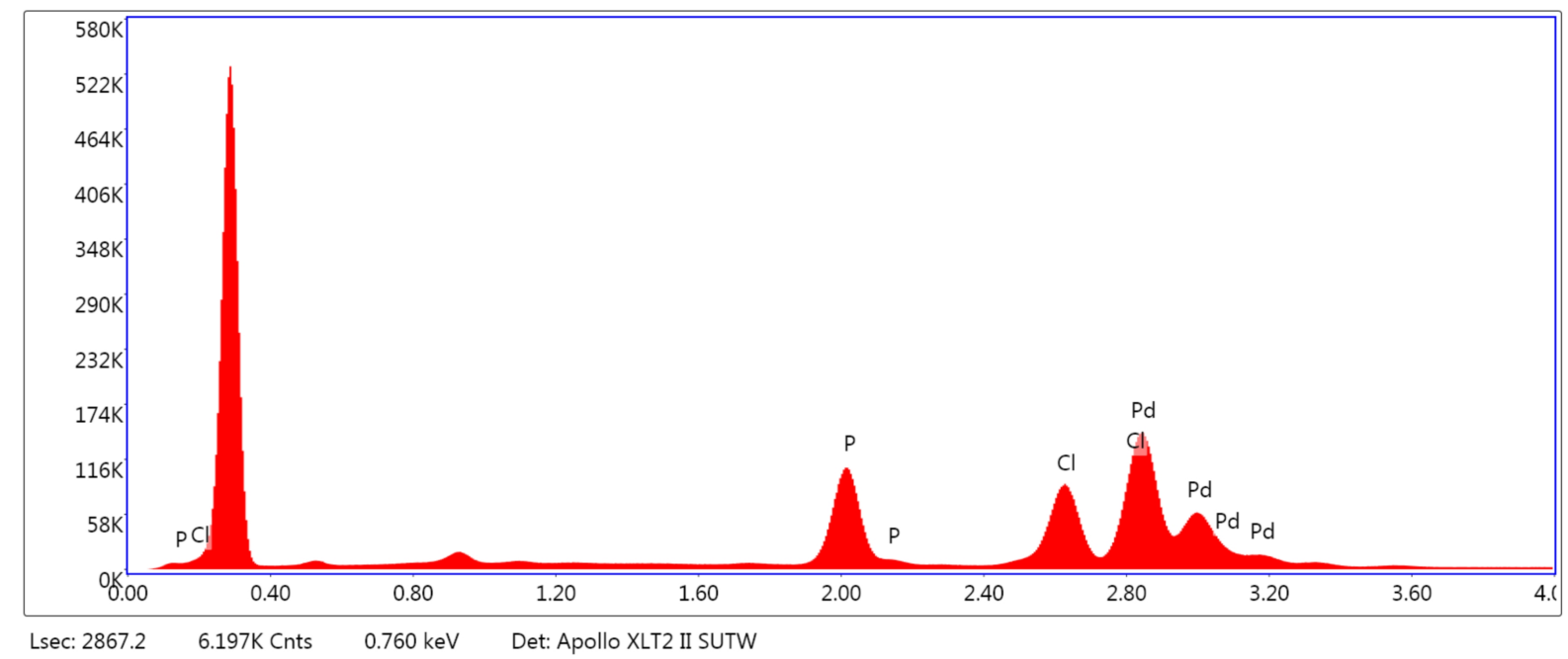

Figure S7. EDAX mapping of the recycled nanoparticles

Table S7. EDAX quantification of constituents

eZAF Smart Quant Results

\begin{tabular}{cccc}
\hline element & atomic \% & net int. & error \% \\
\hline P K & 39.72 & 688.60 & 6.47 \\
ClK & 27.30 & 615.40 & 7.23 \\
PdL & 32.97 & 986.20 & 4.62 \\
\hline
\end{tabular}




\section{CATALYTIC REACTION WITH RECYCLED NPS}

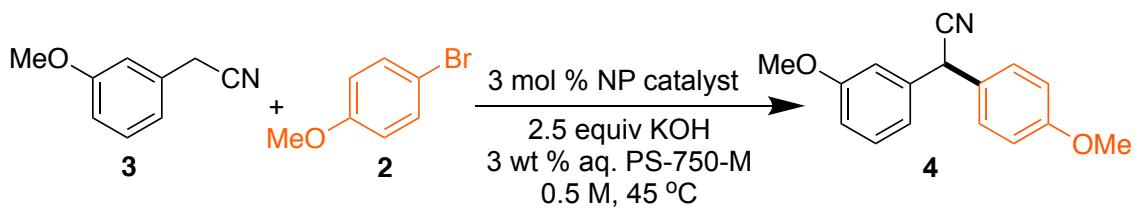

Scheme S6. Catalytic activity with the recycled NPs

$\mathrm{KOH}$ (35 mg, $0.625 \mathrm{mmol}$ ) was added into a $4 \mathrm{~mL}$ oven-dried reaction vial containing PTFEcoated stirrer bar. The reaction vial was evacuated and backfilled with argon for three times. Later, arylacetonitrile 3 (73.5 mg, $0.5 \mathrm{mmol}$ ), 4-bromoanisole 2 (112.2 $\mathrm{mg}, 0.6 \mathrm{mmol}$ ), aqueous solution $(0.5 \mathrm{~mL})$ containing nanoparticles and PS-750-M from the stock solution (SS-1), and $0.5 \mathrm{~mL}$ of 3 wt $\%$ aq. PS-750-M was added to the mixture. The septum was wrapped with PTFE tape and black electrical tape. The reaction mixture was stirred at $45^{\circ} \mathrm{C}$ for $11 \mathrm{~h}$. Then the reaction mixture was allowed to cool to rt. EtOAc $(1.0 \mathrm{~mL})$ was added to the reaction mixture without opening the septum and stirred for a minute at rt. Stirring was stopped and organic layer was allowed to separate. The organic layer was removed using a syringe and this cycle was repeated for an additional time. Combined organic layers were dried over anhydrous sodium sulfate. Volatiles were removed under reduced pressure to obtain the crude product. The crude product was purified by flash chromatography over the silica gel using ethyl acetate/hexanes as eluent; $110 \mathrm{mg}(87 \%)$ and $R_{\mathrm{f}} 0.38$ (1:9, EtOAc/hexanes). The remaining aqueous medium was purged with argon for 5 minutes. Then, 3 (73.5 mg, $0.5 \mathrm{mmol}$ ), 4-bromoanisole 2 (112 mg, $0.6 \mathrm{mmol})$ and $\mathrm{KOH}$ (35 mg, $0.625 \mathrm{mmol}$ ) were sequentially added under the positive argon pressure. Reaction vial was closed with a rubber septum. Septum was sealed with a PTFE tape and black electrical tape. The reaction mixture was stirred at $45^{\circ} \mathrm{C}$ for $11 \mathrm{~h}$. Then the reaction mixture was allowed to cool to rt. EtOAc $(1.0 \mathrm{~mL})$ was added to the reaction mixture and stirred for a minute at rt. Stirring was stopped and organic layer was allowed to separate. The organic layer was removed using a pipette and this cycle was repeated for an additional time. Combined organic layers were dried over anhydrous sodium sulfate. Volatiles were removed under reduced pressure to obtain the crude product. The crude product was purified by flash chromatography over the silica gel using ethyl acetate/hexanes as eluent; $78.7 \mathrm{mg}(62 \%)$ and $R_{\mathrm{f}} 0.38$ (1:9, EtOAc/hexanes). 


\section{ANALYTICAL DATA}

\section{2-(3-Methoxyphenyl)-2-(4-methoxyphenyl)acetonitrile (4)}

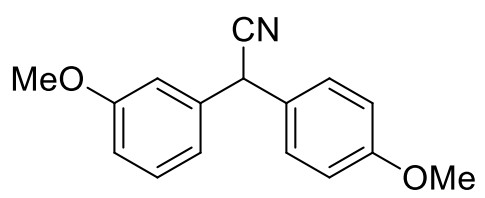

White solid, $\mathrm{mp}=103-105{ }^{\circ} \mathrm{C}$, yield $110 \mathrm{mg}(87 \%), R_{\mathrm{f}} 0.38$ (1:9, EtOAc/hexanes). ${ }^{1} \mathrm{H}$ NMR (400 $\left.\mathrm{MHz}, \mathrm{CDCl}_{3}\right) \delta$ 7.20-7.15 (m, 3H), 6.83-6.74 (m, 5H), $4.97(\mathrm{~s}, 1 \mathrm{H}), 3.70(\mathrm{~s}, 3 \mathrm{H}), 3.69(\mathrm{~s}, 3 \mathrm{H}) .{ }^{13} \mathrm{C}$ NMR $\left(126 \mathrm{MHz}, \mathrm{CDCl}_{3}\right) \delta 160.2,159.6,137.8,130.3,128.9,127.9,120.0,119.9,114.7,113.6$, 113.5 55.5, 55.4, 41.9. IR (v cm-1) $2954(\mathrm{w}), 2700$ (m), 2246 (s), 1732 (m). HRMS (EI) $\left.\left[\mathrm{C}_{16} \mathrm{H}_{15} \mathrm{NO}_{2}\right)+\right]$ calcd $=253.1103$, found $\mathrm{m} / \mathrm{z} 253.1101$

\section{2-phenylpent-4-enenitrile (5) ${ }^{[3]}$}<smiles>C=CCC(C#N)c1ccccc1</smiles>

Viscous oil, yield $27.5 \mathrm{mg}(70 \%), R_{\mathrm{f}} 0.22$ (1:19, EtOAc/hexanes). ${ }^{1} \mathrm{H}$ NMR $\left(500 \mathrm{MHz}, \mathrm{CDCl}_{3}\right) \delta$ 7.4-7.33 (m, 5H), 5.83-5.78 (m, 1H), 5.21-5.18 (m, 2H), 3.87-3.84 (m, 1H), 2.63 (m, 2H).

\section{3-(4-nitrophenyl)-2,4-diphenylpentanedinitrile (6)}<smiles>N#CC(c1ccccc1)C(c1ccccc1)C(C#N)c1ccc([N+](=O)[O-])cc1</smiles>

Yellow waxy solid, yield $49.5 \mathrm{mg}(67 \%), R_{\mathrm{f}} 0.33$ (1:4, EtOAc/hexanes). ${ }^{1} \mathrm{H}$ NMR (400 MHz, $\left.\mathrm{CDCl}_{3}\right) \delta 8.16(\mathrm{~d}, J=8 \mathrm{~Hz}, 2 \mathrm{H}), 7.40-7.39(\mathrm{~m}, 6 \mathrm{H}), 7.31-7.27(\mathrm{~m}, 2 \mathrm{H}), 7.22-7.19(\mathrm{~m}, 4 \mathrm{H}), 4.19$ $(\mathrm{d}, J=8 \mathrm{~Hz}, 2 \mathrm{H}), 3.54(\mathrm{t}, J=8 \mathrm{~Hz}, 1 \mathrm{H}) .{ }^{13} \mathrm{C} \mathrm{NMR}\left(100 \mathrm{MHz}, \mathrm{CDCl}_{3}\right) \delta 148.1,141.7,132.0,129.7$, 129.4, 127.7, 123.8, 117.8, 55.4, 40.5. IR (v cm $\left.{ }^{-1}\right) 2919$ (s), 2906 (s), 2239 (s), 1600 (s), 1485 (s), HRMS (ESI) $\left[\mathrm{C}_{23} \mathrm{H}_{17} \mathrm{~N}_{3} \mathrm{O}_{2}+\mathrm{H}^{+}\right]$calcd $=368.1394$, found $\mathrm{m} / \mathrm{z} 368.1392$.

2-(4-Chlorophenyl)-2-(6-methoxypyridin-3-yl)acetonitrile (7) 


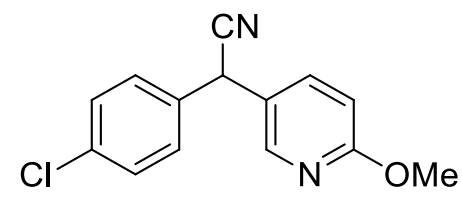

White solid, $\mathrm{mp}=106-107{ }^{\circ} \mathrm{C}$, yield $116 \mathrm{mg}(90 \%), R_{\mathrm{f}} 0.18$ (1:9, EtOAc/hexanes). ${ }^{1} \mathrm{H}$ NMR $(400$ $\left.\mathrm{MHz}, \mathrm{CDCl}_{3}\right) \delta 7.97(\mathrm{~d}, J=2.8 \mathrm{~Hz}, 1 \mathrm{H}), 7.31$ (dd, $\left.J=8.7,2.4 \mathrm{~Hz}, 1 \mathrm{H}\right), 7.19(\mathrm{~d}, J=8.4 \mathrm{~Hz}, 2 \mathrm{H})$, $7.11(\mathrm{~d}, J=8.4 \mathrm{~Hz}, 2 \mathrm{H}), 6.59(\mathrm{~d}, J=8.6 \mathrm{~Hz}, 1 \mathrm{H}), 4.91(\mathrm{~s}, 1 \mathrm{H}), 3.77(\mathrm{~s}, 3 \mathrm{H}) \cdot{ }^{13} \mathrm{C}$ NMR $(100 \mathrm{MHz}$, $\left.\mathrm{CDCl}_{3}\right) \delta 164.3,145.9,137.9,134.7,133.9,129.7,129.0,124.3,118.8,111.9,53.8,39.0$. IR (v $\left.\mathrm{cm}^{-1}\right) 2966(\mathrm{~m}), 2246(\mathrm{~s}), 1608(\mathrm{~m})$. HRMS (EI) $\left.\left[\mathrm{C}_{14} \mathrm{H}_{11} \mathrm{~N}_{2} \mathrm{ClO}\right)^{+}\right]$calcd $=258.0560$, found $\mathrm{m} / \mathrm{z}$ 258.0551 .

2,2-Di(naphthalen-1-yl)acetonitrile (8) (CAS No: 59175-45-0)<smiles>N#CC(c1cccc2ccccc12)c1cccc2ccccc12</smiles>

Viscous oil, yield $112 \mathrm{mg}(77 \%), R_{\mathrm{f}} 0.2$ (1:9, EtOAc/hexanes). ${ }^{1} \mathrm{H}$ NMR $\left(500 \mathrm{MHz}, \mathrm{CDCl}_{3}\right) \delta$ 7.91-7.83 (m, 6H), 7.51-7.37 (m, 8H), $6.49(\mathrm{~s}, 1 \mathrm{H})$.

\section{2-(4-Chlorophenyl)-2-(3,5-dimethylphenyl)acetonitrile (9)}<smiles>Cc1cc(C)cc(C(C#N)c2ccc(Cl)cc2)c1</smiles>

Viscous oil, yield $109 \mathrm{mg}(86 \%), R_{\mathrm{f}} 0.22$ (1:9, EtOAc/hexanes). ${ }^{1} \mathrm{H}$ NMR $\left(400 \mathrm{MHz}, \mathrm{CDCl}_{3}\right) \delta$ 7.39-7.23 (m, 4H), $6.94(\mathrm{~s}, 1 \mathrm{H}), 6.90(\mathrm{~s}, 2 \mathrm{H}), 5.00(\mathrm{~s}, 1 \mathrm{H}), 2.28(\mathrm{~s}, 6 \mathrm{H}) .{ }^{13} \mathrm{C}$ NMR (100 MHz, $\left.\mathrm{CDCl}_{3}\right) \delta 139.2,135.3,134.8,134.4,130.2,129.5,129.2,125.5,119.6,42.0,21.4 . \mathrm{IR}\left(\mathrm{v} \mathrm{cm}^{-1}\right)$ 3019 (s), 2919 (m), 2244 (s), 1604 (s). HRMS (EI) $\left.\left[\mathrm{C}_{16} \mathrm{H}_{14} \mathrm{NCl}\right)^{+}\right]$calcd $=255.0815$, found m/z 255.0808 .

\section{2-(4-Methoxyphenyl)-2-(naphthalen-1-yl)acetonitrile $(10)^{[4]}$}<smiles>COc1ccc(C(C#N)c2cccc3ccccc23)cc1</smiles> 
Viscous oil, yield $112 \mathrm{mg}(82 \%), R_{\mathrm{f}} 0.25$ (1:9, EtOAc/hexanes). ${ }^{1} \mathrm{H} \mathrm{NMR}\left(500 \mathrm{MHz}, \mathrm{CDCl}_{3}\right) \delta$ 7.84-7.80 (m, 3H), 7.58 (d, $J=7.5 \mathrm{~Hz}, 1 \mathrm{H}), 7.46-7.42(\mathrm{~m}, 3 \mathrm{H}), 7.20$ (d, $J=8.5 \mathrm{~Hz}, 2 \mathrm{H}), 6.81-6.79$ $(\mathrm{m}, 2 \mathrm{H}), 5.72(\mathrm{~s}, 1 \mathrm{H}), 3.71(\mathrm{~s}, 3 \mathrm{H})$.

\section{2-(Naphthalen-1-yl)-2-(p-tolyl)acetonitrile (11)}

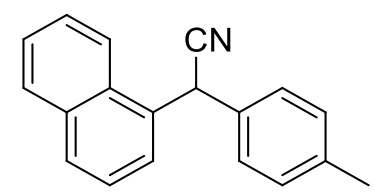

Viscous oil, yield $128 \mathrm{mg}$ (84\%), $R_{\mathrm{f}} 0.2$ (1:9, EtOAc/hexanes). ${ }^{1} \mathrm{H}$ NMR (500 MHz, $\left.\mathrm{CDCl}_{3}\right) \delta$ 7.84-7.80 (m, 3H), $7.58(\mathrm{~d}, J=7.0 \mathrm{~Hz}, 1 \mathrm{H}), 7.45-7.41(\mathrm{~m}, 3 \mathrm{H}), 7.18(\mathrm{~d}, J=8.0 \mathrm{~Hz}, 2 \mathrm{H}), 7.08$ (d, $J=8.0 \mathrm{~Hz}, 2 \mathrm{H}), 5.73(\mathrm{~s}, 1 \mathrm{H}), 2.26(\mathrm{~s}, 3 \mathrm{H}) .{ }^{13} \mathrm{C} \mathrm{NMR}\left(126 \mathrm{MHz}, \mathrm{CDCl}_{3}\right) \delta 138.2,134.3,132.4$, 131.1, 130.5, 129.9, 129.6, 129.2, 127.8 127.2, 127.1, 126.3 125.5, 123.2, 120.0, 39.7, 21.2. IR (v $\left.\mathrm{cm}^{-1}\right) 3019(\mathrm{~s}), 2952(\mathrm{~m}), 2244(\mathrm{~s}), 1706(\mathrm{~s})$. HRMS (CI) $\left[\mathrm{C}_{19} \mathrm{H}_{15} \mathrm{~N}^{+}\right]$calcd $=257.1153$, found $\mathrm{m} / \mathrm{z}$ 257.1197 .

\section{2-(4-Butylphenyl)-2-(naphthalen-1-yl)acetonitrile (12)}

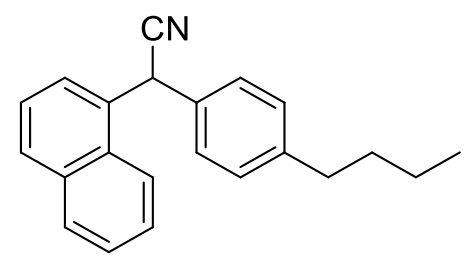

Viscous oil, yield $97 \mathrm{mg}(65 \%), R_{\mathrm{f}} 0.22$ (1:9, EtOAc/hexanes). ${ }^{1} \mathrm{H} \mathrm{NMR}\left(400 \mathrm{MHz}, \mathrm{CDCl}_{3}\right) \delta 7.92-$ $7.87(\mathrm{~m}, 3 \mathrm{H}), 7.65$ (d, $J=7.2 \mathrm{~Hz}, 1 \mathrm{H}), 7.53-7.49$ (m, 3H), 7.26 (d, $J=8.4 \mathrm{~Hz}, 2 \mathrm{H}), 7.16$ (d, $J=$ $8.4 \mathrm{~Hz}, 2 \mathrm{H}), 5.81(\mathrm{~s}, 1 \mathrm{H}), 2.58(\mathrm{t}, \mathrm{J}=8.0 \mathrm{~Hz}, 2 \mathrm{H}), 1.61-1.53(\mathrm{~m}, 2 \mathrm{H}), 1.38-1.29(\mathrm{~m}, 2 \mathrm{H}), 0.92(\mathrm{t}$, $J=7.6 \mathrm{~Hz}, 3 \mathrm{H}) .{ }^{13} \mathrm{C} \mathrm{NMR}\left(100 \mathrm{MHz}, \mathrm{CDCl}_{3}\right) \delta 143.2,134.3,132.5,131.2,130.5,129.5,129.3$, 129.2, 127.8, 127.2, 127.1, 126.3, 125.6, 123.2, 120.1, 39.7, 35.3, 33.6, 22.5, 14.1. IR (v cm$\left.)^{-1}\right)$ 3029 (s), 2952 (s), 2925 (s), 2242 (s), 1510 (s). HRMS (CI) $\left.\left[\mathrm{C}_{22} \mathrm{H}_{21} \mathrm{~N}\right)^{+}\right]$calcd = 299.1674, found $\mathrm{m} / \mathrm{z} 299.1666$.

\section{2,2-diphenylacetonitrile (13) ${ }^{[5]}$}


<smiles>N#CC(c1ccccc1)c1ccccc1</smiles>

Viscous oil, yield $81 \mathrm{mg}(84 \%), R_{\mathrm{f}} 0.3$ (1:19, EtOAc:Hexanes), ${ }^{1} \mathrm{H}$ NMR (500 MHz, $\left.\mathrm{CDCl}_{3}\right) \delta$ 7.39-7.19 (m, 10H), $5.10(\mathrm{~s}, 1 \mathrm{H})$.

\section{2-(4-Methoxyphenyl)-2-phenylacetonitrile (14) ${ }^{[6]}$}<smiles>COc1ccc(C(C#N)c2ccccc2)cc1</smiles>

White solid, yield $101 \mathrm{mg}(91 \%), R_{\mathrm{f}} 0.25$ (1:19, EtOAc/hexanes). ${ }^{1} \mathrm{H}$ NMR $\left(500 \mathrm{MHz}, \mathrm{CDCl}_{3}\right) \delta$ 7.34-7.27 (m, 5H), $7.21(\mathrm{~s}, 1 \mathrm{H}), 7.12(\mathrm{~s}, 1 \mathrm{H}), 6.85-6.83(\mathrm{~m}, 2 \mathrm{H}), 5.05(\mathrm{~s}, 1 \mathrm{H}), 3.75(\mathrm{~s}, 3 \mathrm{H})$.

2-(4-Chlorophenyl)-2-phenylacetonitrile (15) (CAS No: 4578-80-7)<smiles>N#CC(c1ccccc1)c1ccc(Cl)cc1</smiles>

White solid, yield $87 \mathrm{mg}(77 \%), R_{\mathrm{f}} 0.3$ (1:19, EtOAc/hexanes). ${ }^{1} \mathrm{H}$ NMR $\left(400 \mathrm{MHz}, \mathrm{CDCl}_{3}\right) \delta$ 7.35-7.20 (m, 9H), $5.06(\mathrm{~s}, 1 \mathrm{H})$.

2-phenyl-2-(4-(trifluoromethyl)phenyl)acetonitrile (16) ${ }^{[7]}$<smiles>N#CC(c1ccccc1)c1ccc(C(F)(F)F)cc1</smiles>

Colorless oil, yield $86.1 \mathrm{mg}(66 \%), R_{\mathrm{f}} 0.29$ (1:19, EtOAc/hexanes). ${ }^{1} \mathrm{H}$ NMR $\left(500 \mathrm{MHz}, \mathrm{CDCl}_{3}\right)$ $\delta 7.64(\mathrm{~d}, J=5 \mathrm{~Hz}, 2 \mathrm{H}), 7.49(\mathrm{~d}, J=10 \mathrm{~Hz}, 2 \mathrm{H}), 7.42-7.33(\mathrm{~m}, 5 \mathrm{H}), 5.20(\mathrm{~s}, 1 \mathrm{H}).) .{ }^{19} \mathrm{~F}$ NMR $(376$ $\left.\mathrm{MHz}, \mathrm{CDCl}_{3}\right) \delta-59.20(\mathrm{~s})$.

2-(3-Methoxyphenyl)-2-phenylacetonitrile (17) (CAS No: 25310-35-4)<smiles>COc1cccc(C(C#N)c2ccccc2)c1</smiles> 
Sticky solid, yield $97 \mathrm{mg}$ (87\%), $R_{\mathrm{f}} 0.38$ (1:19, EtOAc/hexanes). ${ }^{1} \mathrm{H}$ NMR (400 MHz, $\left.\mathrm{CDCl}_{3}\right) \delta$ 7.32-7.20 (m, 6H), $6.88(\mathrm{~d}, J=7.6 \mathrm{~Hz}, 1 \mathrm{H}), 6.84-6.74(\mathrm{~m}, 2 \mathrm{H}), 5.05(\mathrm{~s}, 1 \mathrm{H}), 3.74(\mathrm{~s}, 3 \mathrm{H})$.

\section{2-(4-Chlorophenyl)-2-(3-methoxyphenyl)acetonitrile (18)}<smiles>COc1cccc(C(C#N)c2ccc(Cl)cc2)c1</smiles>

Sticky solid, yield $100 \mathrm{mg}$ (78\%), $R_{\mathrm{f}} 0.36$ (1:9, EtOAc/hexanes). ${ }^{1} \mathrm{H}$ NMR (500 MHz, $\left.\mathrm{CDCl}_{3}\right) \delta$ 7.29-7.19 (m, 5H), 6.85-6.78 (m, 3H), $5.02(\mathrm{~s}, 1 \mathrm{H}), 3.73(\mathrm{~s}, 3 \mathrm{H}) .{ }^{13} \mathrm{C} \mathrm{NMR}\left(126 \mathrm{MHz}, \mathrm{CDCl}_{3}\right) \delta$ $160.3,136.9,134.5,134.4,130.5,129.5,129.2,120.1,119.3,113.8,113.7,55.5,42.1$. IR $\left(\mathrm{v} \mathrm{cm}^{-1}\right)$ $2950(\mathrm{~m}), 2910(\mathrm{~s}), 2814(\mathrm{~m}), 2321(\mathrm{~s}), 1692(\mathrm{~s})$. HRMS (EI) [C $\left.\left.\mathrm{C}_{15} \mathrm{H}_{12} \mathrm{CINO}\right)+\right]$ calcd $=257.0607$, found $\mathrm{m} / \mathrm{z} 257.0603$.

\section{2-(3,5-Bis(trifluoromethyl)phenyl)-2-(3-methoxyphenyl)acetonitrile (19)}<smiles>COc1cccc(C(C#N)c2cc(C(F)(F)F)cc(C(F)(F)F)c2)c1</smiles>

Yellow viscous oil, yield $140 \mathrm{mg}(78 \%), R_{\mathrm{f}} 0.42$ (1:19, EtOAc/hexanes). ${ }^{1} \mathrm{H}$ NMR (400 MHz, $\left.\mathrm{CDCl}_{3}\right) \delta 7.89(\mathrm{~s}, 1 \mathrm{H}), 7.84(\mathrm{~s}, 2 \mathrm{H}), 7.38(\mathrm{t}, J=8.0 \mathrm{~Hz}, 1 \mathrm{H}), 6.94(\mathrm{~d}, J=8.1 \mathrm{~Hz}, 2 \mathrm{H}), 6.89(\mathrm{~s}, 1 \mathrm{H})$, $5.25(\mathrm{~s}, 1 \mathrm{H}), 3.84(\mathrm{~s}, 3 \mathrm{H}) .{ }^{19} \mathrm{~F} \mathrm{NMR}\left(376 \mathrm{MHz}, \mathrm{CDCl}_{3}\right) \delta-62.95(\mathrm{~s}) .{ }^{13} \mathrm{C} \mathrm{NMR}\left(101 \mathrm{MHz}, \mathrm{CDCl}_{3}\right)$ $\delta 160.6,138.6,135.4,132.9$ (q, $J=33.6 \mathrm{~Hz}), 131,128,122.9$ (q, $J=275 \mathrm{~Hz}), 122.7,120,118.3$, 114.3, 114, 55.6, 42.4. IR, 2937 (w), 2247 (s), 1601 (m). HRMS (EI) $\left.\left[\mathrm{C}_{17} \mathrm{H}_{11} \mathrm{~F}_{6} \mathrm{NO}\right)^{+}\right]$calcd = 359.0745, found $\mathrm{m} / \mathrm{z} 359.0739$.

\section{Benzyl (4-(cyano(phenyl)methyl)phenyl)carbamate (20)}

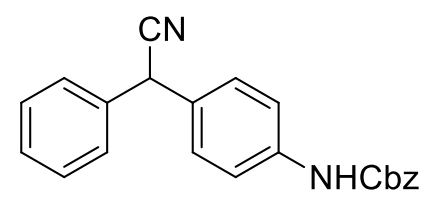

White solid, $\mathrm{mp}=97-99{ }^{\circ} \mathrm{C}$, yield $111 \mathrm{mg}(65 \%), R_{\mathrm{f}} 0.25$ (1:9, EtOAc/hexanes). ${ }^{1} \mathrm{H}$ NMR (400 $\left.\mathrm{MHz}, \mathrm{CDCl}_{3}\right) \delta$ 7.29-7.15 (m, 12H), $7.25(\mathrm{~d}, J=8.4 \mathrm{~Hz}, 2 \mathrm{H}), 6.69(\mathrm{~s}, 1 \mathrm{H}), 5.08(\mathrm{~s}, 2 \mathrm{H}), 4.98(\mathrm{~s}$, 
1H) ${ }^{13}{ }^{\mathrm{C}} \mathrm{NMR}\left(126 \mathrm{MHz}, \mathrm{CDCl}_{3}\right) \delta 153.3,137.9,136.0,135.9,130.9,129.3,128.7,128.6,128.5$, 128.4, 128.3, 127.8, 119.7, 119.3, 67.3, 42.1. IR (v cm$\left.{ }^{-1}\right) 3300$ (s), 2934 (s), 2910 (s), 2243 (s), 1707 (s), 1597 (s). HRMS (CI) $\left.\left[\mathrm{C}_{22} \mathrm{H}_{18} \mathrm{~N}_{2} \mathrm{O}_{2}+\mathrm{H}\right)^{+}\right]$calcd $=343.1441$, found $\mathrm{m} / \mathrm{z} 343.1442$.

\section{2-(Benzo[d][1,3] dioxol-5-yl)-2-(p-tolyl)acetonitrile (21)}

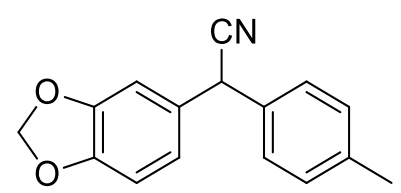

Pale yellow liquid, yield $95 \mathrm{mg}(76 \%), R_{\mathrm{f}} 0.4$ (1:5, EtOAc/hexanes). ${ }^{1} \mathrm{H}$ NMR (400 MHz, $\mathrm{CDCl}_{3}$ ) $\delta$ 7.18-7.11 (m, 4H), 6.74-6.67 (m, 3H), $5.88(\mathrm{~s}, 2 \mathrm{H}), 4.94(\mathrm{~s}, 1 \mathrm{H}), 2.27(\mathrm{~s}, 3 \mathrm{H}) .{ }^{13} \mathrm{C}$ NMR $(100$ $\left.\mathrm{MHz}, \mathrm{CDCl}_{3}\right) \delta 148.5,147.6,138.3,133.1,129.9,129.0,127.6,121.3,119.9,108.7,108.3,101.6$, 42.03, 21.20. IR $\left(v \mathrm{~cm}^{-1}\right) 2992(\mathrm{~s}), 2148(\mathrm{~s}), 1603(\mathrm{~s})$. HRMS (CI) $\left.\left[\mathrm{C}_{16} \mathrm{H}_{13} \mathrm{NO}_{2}+\mathrm{H}\right)^{+}\right]$calcd $=$ 251.0946, found $\mathrm{m} / \mathrm{z} 251.0935$.

\section{2-(3-bromo-4-methoxyphenyl)-2-(3-methoxyphenyl)acetonitrile (22)}<smiles>COc1cccc(C(C#N)c2ccc(OC)c(Br)c2)c1</smiles>

Brown sticky solid, yield $119 \mathrm{mg}(72 \%), R_{\mathrm{f}} 0.28$ (1:9, EtOAc/hexanes). ${ }^{1} \mathrm{H}$ NMR (500 MHz, $\left.\mathrm{CDCl}_{3}\right) \delta 7.44(\mathrm{~d}, J=2.3 \mathrm{~Hz}, 1 \mathrm{H}), 7.25-7.20(\mathrm{~m}, 2 \mathrm{H}), 6.85-6.78(\mathrm{~m}, 4 \mathrm{H}), 4.97(\mathrm{~s}, 1 \mathrm{H}), 3.83(\mathrm{~s}$, 3H), $3.74(\mathrm{~s}, 3 \mathrm{H}) .{ }^{13} \mathrm{C}$ NMR $\left(126 \mathrm{MHz}, \mathrm{CDCl}_{3}\right) \delta 160.3,137.1,132.7,130.5,129.3,127.9,120.0$, 119.4, 116.4, 113.8, 113.7, 112.5, 112.3, 56.5, 55.5, 41.5. IR (v cm $\left.{ }^{-1}\right) 3010(\mathrm{w}), 2942(\mathrm{w}), 2806$ (s), $2193(\mathrm{w}), 1889(\mathrm{~s})$. HRMS (EI) $\left.\left[\mathrm{C}_{16} \mathrm{H}_{14} \mathrm{NO}_{2} \mathrm{Br}+\mathrm{H}\right)^{+}\right]$calcd = 331.0208, found m/z 331.0197.

\section{2-(4-Chlorophenyl)-2-(m-tolyl)acetonitrile (23)}<smiles>Cc1cccc(C(C#N)c2ccc(Cl)cc2)c1</smiles>

Viscous oil, yield $109 \mathrm{mg}(91 \%), R_{\mathrm{f}} 0.23$ (1:9, EtOAc/hexanes). ${ }^{1} \mathrm{H}$ NMR (500 MHz, $\left.\mathrm{CDCl}_{3}\right) \delta$ $7.24(\mathrm{~d}, J=8.5 \mathrm{~Hz}, 2 \mathrm{H}), 7.21-7.14(\mathrm{~m}, 3 \mathrm{H}), 7.05-7.01(\mathrm{~m}, 3 \mathrm{H}), 4.97(\mathrm{~s}, 1 \mathrm{H}), 2.25(\mathrm{~s}, 3 \mathrm{H}) .{ }^{13} \mathrm{C} \mathrm{NMR}$ $\left(126 \mathrm{MHz} \mathrm{CDCl}_{3}\right) \delta 139.3,135.4,134.7,134.4,129.4,129.3,129.2,129.1,128.4,124.8,119.5$, 
42.0, $\left.21.5 \mathrm{IR}\left(\mathrm{v} \mathrm{cm}^{-1}\right) 2918(\mathrm{~s}), 2910(\mathrm{~s}), 2243(\mathrm{~s}), 1603(\mathrm{~s}) . \mathrm{HRMS}(\mathrm{EI})\left[\mathrm{C}_{15} \mathrm{H}_{12} \mathrm{ClN}\right)^{+}\right] \mathrm{calcd}=$ 241.0653 , found $\mathrm{m} / \mathrm{z} 241.0655$.

\section{2-(4-Chlorophenyl)-2-(4-methoxyphenyl)acetonitrile (24)}<smiles>COc1ccc(C(C#N)c2ccc(Cl)cc2)cc1</smiles>

Viscous oil, yield $118 \mathrm{mg}(92 \%), R_{\mathrm{f}} 0.22$ (1:9, EtOAc/hexanes). ${ }^{1} \mathrm{H}$ NMR $\left(500 \mathrm{MHz}, \mathrm{CDCl}_{3}\right) \delta$ $7.26(\mathrm{~d}, J=8.5 \mathrm{~Hz}, 2 \mathrm{H}), 7.18(\mathrm{~d}, J=8.5 \mathrm{~Hz}, 2 \mathrm{H}), 7.16(\mathrm{~d}, J=9.0 \mathrm{~Hz}, 2 \mathrm{H}), 6.82(\mathrm{~d}, J=9.0 \mathrm{~Hz}$, 2H), 5.00 (s, 1H), 3.73 (s, 3H). ${ }^{13} \mathrm{C}$ NMR (126 MHz, $\left.\mathrm{CDCl}_{3}\right) \delta 159.7,134.9,134.4,129.4,129.1$, 128.9, 127.5, 119.6, 114.8, 55.5, 41.4. IR (v cm $\left.{ }^{-1}\right) 2966$ (s), 2942 (s), 2247 (s), 1609 (s). HRMS (EI) $\left.\left[\mathrm{C}_{15} \mathrm{H}_{12} \mathrm{NOCl}\right)^{+}\right]$calcd $=257.0607$, found $\mathrm{m} / \mathrm{z} 257.0603$.

\section{2-([1,1'-Biphenyl]-4-yl)-2-(4-chlorophenyl)acetonitrile (25)}<smiles>N#CC(c1ccc(Cl)cc1)c1ccc(-c2ccccc2)cc1</smiles>

White solid, $\mathrm{mp}=114-116{ }^{\circ} \mathrm{C}$, yield $116 \mathrm{mg}(77 \%), R_{\mathrm{f}} 0.25$ (1:9, EtOAc/hexanes). ${ }^{1} \mathrm{H}$ NMR (400 $\left.\mathrm{MHz} \mathrm{CDCl}_{3}\right) \delta$ 7.62-7.56 (m, 4H), 7.47-7.32 (m, 9H), $5.16(\mathrm{~s}, 1 \mathrm{H}) .{ }^{13} \mathrm{C} \mathrm{NMR}\left(100 \mathrm{MHz}, \mathrm{CDCl}_{3}\right)$ $\delta 141.7,140.1,134.6,134.5,134.5,129.6,129.2,129.0,128.2$, 128.1, 127.8, 127.2, 119.3, 41.8 . IR (v cm $\left.{ }^{-1}\right) 3029$ (s), 2925 (m), 2242 (s), 1492 (s), 1484 (s), 1412 (s), 1320 (m), 1216 (s), 1093 (s), 1072 (m), 1017 (m), 847 (s), 816 (s), 760 (s), 667 (m). IR (v cm-1) 3029 (m), 2925 (m), 2242 (s), $1517(\mathrm{w})$. HRMS (EI) $\left.\left[\mathrm{C}_{20} \mathrm{H}_{14} \mathrm{NCl}\right)^{+}\right]$calcd $=303.0815$, found $\mathrm{m} / \mathrm{z} 303.0809$.

\section{2-(4-Chlorophenyl)-2-(9H-fluoren-2-yl)acetonitrile (26)}<smiles>N#CC(c1ccc(Cl)cc1)c1ccc2c(c1)Cc1ccccc1-2</smiles> 
White solid, $\mathrm{mp}=107-108{ }^{\circ} \mathrm{C}$, yield $138 \mathrm{mg}(88 \%), R_{\mathrm{f}} 0.25$ (1:9, EtOAc/hexanes). ${ }^{1} \mathrm{H}$ NMR (400 $\left.\mathrm{MHz}, \mathrm{CDCl}_{3}\right) \delta 7.77(\mathrm{dd}, J=7.2,3.2 \mathrm{~Hz}, 2 \mathrm{H}), 7.55(\mathrm{~d}, J=7.2 \mathrm{~Hz}, 1 \mathrm{H}), 7.50(\mathrm{~s}, 1 \mathrm{H}), 7.41-7.31$ $(\mathrm{m}, 7 \mathrm{H}), 5.19(\mathrm{~s}, 1 \mathrm{H}), 3.89(\mathrm{~s}, 2 \mathrm{H}) .{ }^{13} \mathrm{C} \mathrm{NMR}\left(100 \mathrm{MHz}, \mathrm{CDCl}_{3}\right) \delta 144.5,143.5,142.3,140.8$, $134.8,134.5,133.8,129.5,129.2,127.4,127.1,126.6,125.3,124.5,120.6,120.3,119.6,42.2$, 37.0. IR $\left(v \mathrm{~cm}^{-1}\right) 2927(\mathrm{~m}), 2247(\mathrm{~s}), 1574(\mathrm{~s})$. HRMS (EI) $\left.\left[\mathrm{C}_{21} \mathrm{H}_{14} \mathrm{NCl}\right)^{+}\right]$calcd $=315.0815$, found $\mathrm{m} / \mathrm{z} 315.0807$.

\section{2-(Anthracen-9-yl)-2-(4-chlorophenyl)acetonitrile (27)}

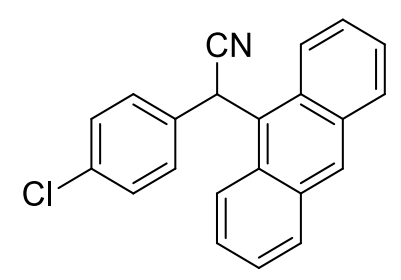

White solid, $\mathrm{mp}=130-132{ }^{\circ} \mathrm{C}$, yield $138 \mathrm{mg}(85 \%), R_{\mathrm{f}} 0.26$ (1:9, EtOAc/hexanes). ${ }^{1} \mathrm{H}$ NMR (500 $\left.\mathrm{MHz} \mathrm{CDCl}_{3}\right) \delta 8.77(\mathrm{~d}, J=8.4 \mathrm{~Hz}, 1 \mathrm{H}), 8.69(\mathrm{~d}, J=8.4 \mathrm{~Hz}, 1 \mathrm{H}), 7.96-7.90(\mathrm{~m}, 2 \mathrm{H}), 7.81(\mathrm{~d}, J=$ 8.1 Hz, 1H), 7.74-7.64 (m, 3H), $7.57(\mathrm{t}, J=8.1 \mathrm{~Hz}, 1 \mathrm{H}), 7.35-7.32(\mathrm{~m}, 4 \mathrm{H}), 5.82(\mathrm{~s}, 1 \mathrm{H}) .{ }^{13} \mathrm{C} \mathrm{NMR}$ $\left(101 \mathrm{MHz} \mathrm{CDCl}_{3}\right) \delta 134.7,133.7,131.4,130.9,130.8,129.6,129.3,129.1,128.8,128.7,128.5$, 127.9, 127.4, 127.3, 127.2, 124.0, 123.8, 122.7, 119.4, 40.1. IR (v cm $\left.{ }^{-1}\right) 3019$ (s), 2243 (s), 1491. HRMS (EI) $\left.\left[\mathrm{C}_{22} \mathrm{H}_{14} \mathrm{NCl}\right)^{+}\right]$calcd $=327.0815$, found $\mathrm{m} / \mathrm{z} 327.0807$.

\section{2-(Anthracen-9-yl)-2-(naphthalen-1-yl)acetonitrile (28)}

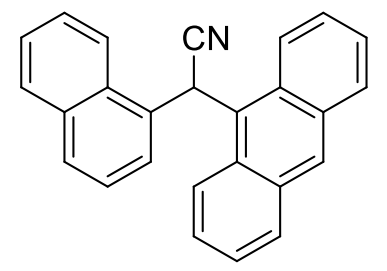

White solid, $\mathrm{mp}=204-206{ }^{\circ} \mathrm{C}$, yield $135 \mathrm{mg}(79 \%), R_{\mathrm{f}} 0.26$ (1:9, EtOAc/hexanes). ${ }^{1} \mathrm{H}$ NMR $(500$ $\left.\mathrm{MHz} \mathrm{CDCl}_{3}\right) \delta 8.80(\mathrm{~d}, J=8.0 \mathrm{~Hz}, 1 \mathrm{H}), 8.71(\mathrm{~d}, J=8.0 \mathrm{~Hz}, 1 \mathrm{H}), 8.05-8.03(\mathrm{~m}, 1 \mathrm{H}), 7.98-7.96$ (m, 1H), 7.91-7.88 (m, 2H), $7.83(\mathrm{~d}, J=8.0 \mathrm{~Hz}, 2 \mathrm{H}), 7.72-7.68(\mathrm{~m}, 2 \mathrm{H}), 7.63-7.54(\mathrm{~m}, 4 \mathrm{H}), 7.47$ $(\mathrm{d}, J=7.5 \mathrm{~Hz}, 1 \mathrm{H}), 7.40(\mathrm{~d}, J=7.5 \mathrm{~Hz}, 1 \mathrm{H}), 6.55(\mathrm{~s}, 1 \mathrm{H}) .{ }^{13} \mathrm{C} \mathrm{NMR}\left(126 \mathrm{MHz}, \mathrm{CDCl}_{3}\right) \delta 134.3$, $131.3,131.1,130.7,130.4,129.7,129.4,129.3,129.2$, 128.8, 128.7, 127.8, 127.6, 127.3, 127.2, 126.5, 125.7, 123.8, 123.7, 122.7, 122.6, 119.5, 36.7. IR (v cm-1) 3065 (m), 2987 (m), 2239 (s), $\left.1598(\mathrm{~s}) . \mathrm{HRMS}(\mathrm{CI})\left[\mathrm{C}_{26} \mathrm{H}_{17} \mathrm{~N}+\mathrm{H}\right)^{+}\right]$calcd $=344.1434$, found $\mathrm{m} / \mathrm{z} 344.1434$ 


\section{2-([1,1'-biphenyl]-4-yl)-2-(naphthalen-1-yl)acetonitrile (29)}

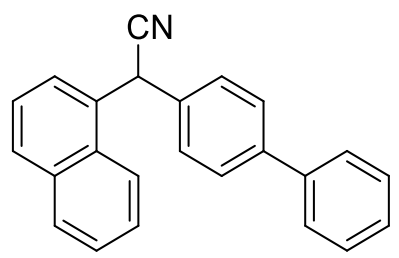

Reaction ran at $0.3 \mathrm{mmol}$ scale. White solid, $\mathrm{mp}=166-167{ }^{\circ} \mathrm{C}$, yield $81 \mathrm{mg}(85 \%), R_{\mathrm{f}} 0.22(1: 9$, EtOAc/hexanes). ${ }^{1} \mathrm{H}$ NMR (500 MHz, $\left.\mathrm{CDCl}_{3}\right) \delta$ 7.94-7.90 (m, 3H), $7.70(\mathrm{~d}, J=7.1 \mathrm{~Hz}, 1 \mathrm{H}), 7.62$ $-7.48(\mathrm{~m}, 7 \mathrm{H}), 7.47-7.39(\mathrm{~m}, 4 \mathrm{H}), 7.36(\mathrm{t}, J=7.1 \mathrm{~Hz}, 1 \mathrm{H}), 5.88(\mathrm{~s}, 1 \mathrm{H}) .{ }^{13} \mathrm{C}$ NMR $(126 \mathrm{MHz}$, $\left.\mathrm{CDCl}_{3}\right) \delta 141.4,140.3,134.4,134.3,130.9,130.5,129.7,129.3,128.9,128.3,127.9,127.7,127.3$, 127.2, 127.1, 126.4, 125.6, 123.2, 119.9, 39.7. IR (v cm-1) 3031 (s), 2952 (s), 2241 (s), 1598 (s), $1582(\mathrm{~m})$. HRMS (CI) $\left.\left[\mathrm{C}_{24} \mathrm{H}_{17} \mathrm{~N}+\mathrm{H}\right)^{+}\right]$calcd $=320.1434$, found $\mathrm{m} / \mathrm{z} 320.1438$.

2-(4-Methoxyphenyl)-2-(4-phenoxyphenyl)acetonitrile (30) (CAS No: 1083248-18-3)

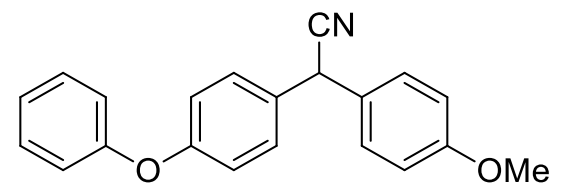

Reaction ran at $0.3 \mathrm{mmol}$ scale. Pale yellow solid, yield $77 \mathrm{mg}(82 \%), R_{f} 0.21$ (1:5, EtOAc/hexanes). ${ }^{1} \mathrm{H}$ NMR (400 MHz, $\left.\mathrm{CDCl}_{3}\right) \delta 7.29(\mathrm{t}, J=8.0 \mathrm{~Hz}, 2 \mathrm{H}), 7.23-7.19(\mathrm{~m}, 4 \mathrm{H}), 7.07$ $(\mathrm{t}, J=8.0 \mathrm{~Hz}, 1 \mathrm{H}), 6.96-6.91(\mathrm{~m}, 4 \mathrm{H}), 6.84(\mathrm{~d}, J=8.8 \mathrm{~Hz}, 2 \mathrm{H}), 5.02(\mathrm{~s}, 1 \mathrm{H}), 3.75(\mathrm{~s}, 3 \mathrm{H})$.

\section{2-(3-Methoxyphenyl)-2-(6-methoxypyridin-3-yl)acetonitrile (31)}

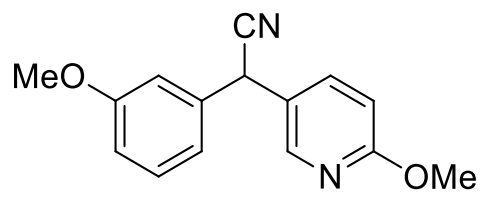

Brown solid, $\mathrm{mp}=92-94{ }^{\circ} \mathrm{C}$, yield $101.6 \mathrm{mg}(80 \%), R_{\mathrm{f}} 0.4$ (1:4, EtOAc/hexanes). ${ }^{1} \mathrm{H}$ NMR (400 $\left.\mathrm{MHz}, \mathrm{CDCl}_{3}\right) \delta 8.15(\mathrm{~d}, J=2.4 \mathrm{~Hz}, 1 \mathrm{H}), 7.50(\mathrm{dd}, J=8.6,2.5 \mathrm{~Hz}, 1 \mathrm{H}), 7.31-7.26(\mathrm{~m}, 1 \mathrm{H}), 6.92$ $(\mathrm{d}, J=7.6 \mathrm{~Hz}, 1 \mathrm{H}), 6.86-6.85(\mathrm{~m}, 2 \mathrm{H}), 6.74(\mathrm{~d}, J=8.7 \mathrm{~Hz}, 1 \mathrm{H}), 5.06(\mathrm{~s}, 1 \mathrm{H}), 3.92(\mathrm{~s}, 3 \mathrm{H}), 3.79(\mathrm{~s}$, 3H). ${ }^{13} \mathrm{C} \mathrm{NMR}\left(176 \mathrm{MHz}, \mathrm{CDCl}_{3}\right) \delta 164.2,160.4,145.9,137.9,136.8,130.5,124.8,119.9,119.2$, 113.9, 113.6, 111.8, 55.5, 53.8, 53.7. IR (v cm-1) 2962 (m), 2207 (s), 1473 (s), 1370 (w), $1278(\mathrm{~s})$, $1136(\mathrm{~m})$. HRMS (CI) $\left.\left[\mathrm{C}_{15} \mathrm{H}_{14} \mathrm{~N}_{2} \mathrm{O}_{2}+\mathrm{H}\right)^{+}\right]$calcd $=254.1055$, found $\mathrm{m} / \mathrm{z} 254.1047$. 


\section{2-(2,2-difluorobenzo[d][1,3]dioxol-5-yl)-2-(3-methoxyphenyl)acetonitrile (32)}<smiles>COc1cccc(C(C#N)c2ccc3c(c2)OC(F)(F)O3)c1</smiles>

Yellow viscous liquid, yield $121.2 \mathrm{mg}(80 \%), R_{\mathrm{f}} 0.42$ (1:9, EtOAc/hexanes). ${ }^{1} \mathrm{H}$ NMR (400 MHz, $\left.\mathrm{CDCl}_{3}\right) \delta 7.31(\mathrm{t}, J=7.9 \mathrm{~Hz}, 1 \mathrm{H}), 7.16-7.02(\mathrm{~m}, 3 \mathrm{H}), 6.92-6.84(\mathrm{~m}, 3 \mathrm{H}), 5.09(\mathrm{~s}, 1 \mathrm{H}), 3.81(\mathrm{~s}$, 3H). ${ }^{19} \mathrm{~F}$ NMR $\left(376 \mathrm{MHz}, \mathrm{CDCl}_{3}\right) \delta-49.80 .{ }^{13} \mathrm{C} \mathrm{NMR}\left(101 \mathrm{MHz}, \mathrm{CDCl}_{3}\right) \delta 160.4,136.7,132.1$, 130.6, 129.2, 124.8, 123.3, 118.9, 119.1, 113.9, 113.8, 111.0, 110.0, 109.3, 55.5, 42.3. IR (v cm$\left.)^{-1}\right)$ $\left.2982(\mathrm{w}), 2254(\mathrm{~s}), 1602(\mathrm{~s}), 1512(\mathrm{~s}) . \mathrm{HRMS}(\mathrm{CI})\left[\mathrm{C}_{16} \mathrm{H}_{11} \mathrm{~F}_{2} \mathrm{NO}_{3}+\mathrm{H}\right)^{+}\right]$calcd $=303.0707$, found $\mathrm{m} / \mathrm{z} 303.0701$.

\section{2-(6-Methoxypyridin-3-yl)-2-(naphthalen-1-yl)acetonitrile (33)}

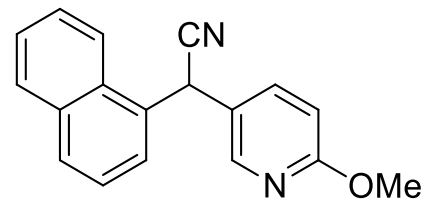

Viscous oil, yield $107 \mathrm{mg}(78 \%), R_{\mathrm{f}} 0.21$ (1:9, EtOAc/hexanes). ${ }^{1} \mathrm{H}$ NMR (400 MHz, $\left.\mathrm{CDCl}_{3}\right) \delta$ 8.07-8.05 (m, 1H), 7.91-7.87 (m, 2H), $7.80(\mathrm{~d}, J=7.6 \mathrm{~Hz}, 1 \mathrm{H}), 7.55-7.44(\mathrm{~m}, 4 \mathrm{H}), 6.78(\mathrm{~d}, J=7.6$ $\mathrm{Hz}, 1 \mathrm{H}), 6.65(\mathrm{~d}, J=8.4 \mathrm{~Hz}, 1 \mathrm{H}), 5.89(\mathrm{~s}, 1 \mathrm{H}), 3.95(\mathrm{~s}, 3 \mathrm{H}) \cdot{ }^{13} \mathrm{C} \mathrm{NMR}\left(100 \mathrm{MHz}, \mathrm{CDCl}_{3}\right) \delta 163.9$, $152.7,139.7,134.2,130.6,130.5,129.6,129.2$, 126.9, 126.3, 125.6, 125.4, 123.6, 119.5, 114.9, 110.5, 53.8, 42.78. IR (v cm $\left.{ }^{-1}\right) 3018$ (s), 2952 (m), 2246 (s), 1600 (m), 1574 (s). HRMS (EI) $\left.\left[\mathrm{C}_{18} \mathrm{H}_{14} \mathrm{~N}_{2} \mathrm{O}\right)^{+}\right]$calcd $=274.1106$, found $\mathrm{m} / \mathrm{z} 274.1100$.

\section{2-([1,1'-biphenyl]-4-yl)-2-(4-phenylthiazol-2-yl)acetonitrile (34)}

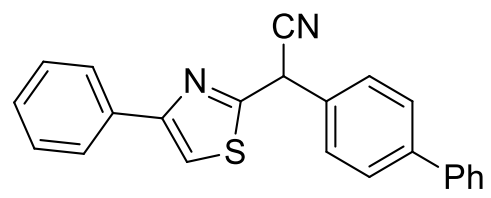

Viscous oil, yield $91 \mathrm{mg}(52 \%), R_{\mathrm{f}} 0.26$ (1:9, EtOAc/hexanes). ${ }^{1} \mathrm{H} \mathrm{NMR}\left(500 \mathrm{MHz}, \mathrm{CDCl}_{3}\right) \delta 7.93$ $7.91(\mathrm{~m}, 2 \mathrm{H}), 7.67-7.65(\mathrm{~m}, 2 \mathrm{H}), 7.64-7.59(\mathrm{~m}, 4 \mathrm{H}), 7.48-7.43(\mathrm{~m}, 5 \mathrm{H}), 7.40-7.35(\mathrm{~m}, 2 \mathrm{H}), 5.66$ $(\mathrm{s}, 1 \mathrm{H}) .{ }^{13} \mathrm{C} \mathrm{NMR}\left(126 \mathrm{MHz}, \mathrm{CDCl}_{3}\right) \delta 163.9,156.3,142.3,140.1,133.9,132.3,129.0,128.9$, 
128.7, 128.4, 128.3, 127.9, 127.3, 126.6, 117.6, 114.6, 41.2. IR (v cm$\left.{ }^{-1}\right) 3013(\mathrm{~s}), 2935(\mathrm{~m}), 2242$ (s), $1586(\mathrm{~s})$. HRMS (EI) $\left.\left[\mathrm{C}_{23} \mathrm{H}_{16} \mathrm{~N}_{2} \mathrm{~S}\right)^{+}\right]$calcd $=352.1034$, found $\mathrm{m} / \mathrm{z} 352.1021$.

\section{2-(4-Chlorophenyl)-2-(4-((3,4-dihydro-1H-pyrido[3,4-b]indol-2(9H)}

yl)methyl)phenyl)acetonitrile (35)

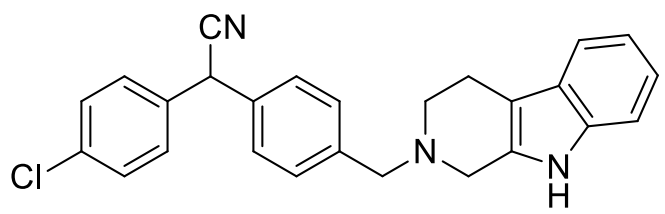

Reaction ran at $0.3 \mathrm{mmol}$ scale. Viscous oil, yield $98 \mathrm{mg}(80 \%), R_{\mathrm{f}} 0.23$ (4:6, EtOAc/hexanes). ${ }^{1} \mathrm{H}$ NMR (500 MHz, $\left.\mathrm{CDCl}_{3}\right) \delta 7.88(\mathrm{~s}, 1 \mathrm{H}), 7.63(\mathrm{~d}, J=7.5 \mathrm{~Hz}, 1 \mathrm{H}), 7.57(\mathrm{~d}, J=8.0 \mathrm{~Hz}, 2 \mathrm{H}), 7.50$ $(\mathrm{d}, J=8.0 \mathrm{~Hz}, 2 \mathrm{H}), 7.44-7.39(\mathrm{~m}, 5 \mathrm{H}), 7.29-7.23(\mathrm{~m}, 2 \mathrm{H}), 5.23(\mathrm{~s}, 1 \mathrm{H}), 3.89(\mathrm{~s}, 2 \mathrm{H}), 3.74(\mathrm{~s}, 2 \mathrm{H})$, 3.04-2.95 (m, 4H). ${ }^{13} \mathrm{C} \mathrm{NMR}\left(126 \mathrm{MHz}, \mathrm{CDCl}_{3}\right) \delta 139.2,136.1,134.5,134.4,131.8,130.1,129.8$, $129.5,129.1,127.8,127.3,121.5,119.5,119.5,119.4,118.1,110.8,108.4,61.4,50.9,50.3,41.8$, 21.3. IR (v cm $\left.{ }^{-1}\right) 3019(\mathrm{~m}), 2930(\mathrm{~m}), 2236(\mathrm{~s}), 1591(\mathrm{~s})$. HRMS (CI) $\left.\left[\mathrm{C}_{26} \mathrm{H}_{22} \mathrm{~N}_{3} \mathrm{Cl}+\mathrm{H}\right)^{+}\right]$calcd = 411.1502, found $\mathrm{m} / \mathrm{z} 412.1578$.

\section{2-(3-methoxyphenyl)-2-(4-((4-phenyl-1H-1,2,3-triazol-1-yl)methyl)phenyl)acetonitrile (36)}

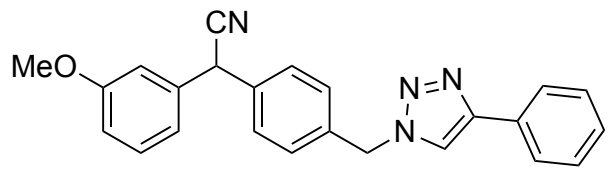

Reaction ran at $0.3 \mathrm{mmol}$ scale. Viscous oil, yield $74 \mathrm{mg}(65 \%), R_{\mathrm{f}} 0.18$ (1:5, EtOAc/hexanes). ${ }^{1} \mathrm{H}$ NMR $\left(500 \mathrm{MHz}, \mathrm{CDCl}_{3}\right) \delta 8.19(\mathrm{~d}, J=7.4 \mathrm{~Hz}, 2 \mathrm{H}), 8.08(\mathrm{~s}, 1 \mathrm{H}), 7.79-7.65(\mathrm{~m}, 9 \mathrm{H}), 7.34-7.28$ $(\mathrm{m}, 1 \mathrm{H}), 7.27-7.24(\mathrm{~m}, 1 \mathrm{H}), 5.96(\mathrm{~s}, 2 \mathrm{H}), 5.50(\mathrm{~s}, 1 \mathrm{H}), 4.18(\mathrm{~s}, 3 \mathrm{H}) .{ }^{13} \mathrm{C} \mathrm{NMR}\left(126 \mathrm{MHz}, \mathrm{CDCl}_{3}\right)$ $\delta 160.3,148.5,136.9,136.6,135.1,130.5,128.9,128.8,128.6,128.4,127.2$, 125.8, 120.1, 119.7, 119.4, 113.8, 113.7, 55.5, 53.7, 42.4. IR (v cm-1) 3013 (m), 2935 (m), 2242 (s), 1600 (s), $1586(\mathrm{~s})$, $1513(\mathrm{~m})$. HRMS (EI) $\left.\left[\mathrm{C}_{24} \mathrm{H}_{20} \mathrm{~N}_{4} \mathrm{O}\right)^{+}\right]$calcd $=380.1637$, found $\mathrm{m} / \mathrm{z} 380.1627$.

\section{2-(1-Benzyl-1H-indol-5-yl)-2-(4-chlorophenyl)acetonitrile (37)}




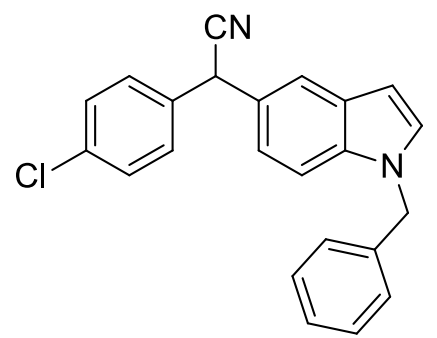

Viscous oil, yield $132 \mathrm{mg}(74 \%), R_{\mathrm{f}} 0.25$ (1:20, EtOAc/hexanes). ${ }^{1} \mathrm{H}$ NMR $\left(400 \mathrm{MHz}, \mathrm{CDCl}_{3}\right) \delta$ $7.56(\mathrm{~s}, 1 \mathrm{H}), 7.27-7.20(\mathrm{~m}, 8 \mathrm{H}), 7.13(\mathrm{~d}, J=3.0 \mathrm{~Hz}, 1 \mathrm{H}), 7.05(\mathrm{~d}, J=7.6 \mathrm{~Hz}, 2 \mathrm{H}), 7.01$ (d, $J=8.4$ $\mathrm{Hz}, 1 \mathrm{H}), 6.49(\mathrm{~d}, J=3.0 \mathrm{~Hz}, 1 \mathrm{H}), 5.26(\mathrm{~s}, 2 \mathrm{H}), 5.15(\mathrm{~s}, 1 \mathrm{H}) .{ }^{13} \mathrm{C} \mathrm{NMR}\left(100 \mathrm{MHz}, \mathrm{CDCl}_{3}\right) \delta 137.1$, $135.9,135.5,133.9,129.7,129.2,129.1,129,128.9,127.9,126.8,126.7,121.3,120.3,120.1$, 110.7, 102.0, 50.3, 42.1. IR (v cm-1) 3029 (s), 2919 (m), 2240 (s), 1511 (w). HRMS (ESI) $\left.\left[\mathrm{C}_{23} \mathrm{H}_{17} \mathrm{~N}_{2} \mathrm{Cl}\right)^{+}\right]$calcd $=356.1080$, found $\mathrm{m} / \mathrm{z} 356.1070$.

\section{2-(4-Chlorophenyl)-2-(4-(1-(10,13-dimethyl-17-(6-methylheptan-2-yl)-}

\section{$2,3,4,7,8,9,10,11,12,13,14,15,16,17$-tetradecahydro-1 $H$-cyclopenta[a]phenanthren-3-yl)-1H-}

\section{1,2,3-triazol-4-yl)phenyl)acetonitrile (38)}

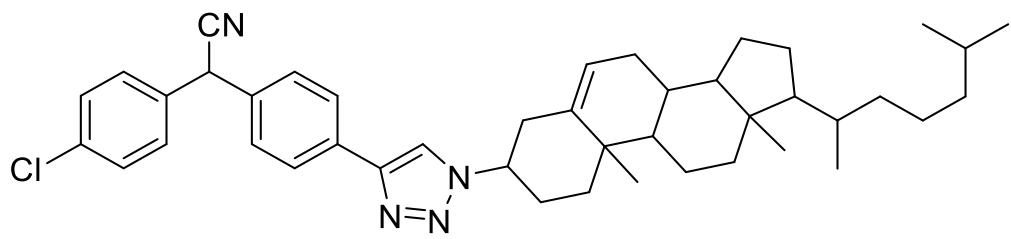

Catalytic reaction performed at $0.3 \mathrm{mmol}$ scale. White solid, $\mathrm{mp}=199-201{ }^{\circ} \mathrm{C}$, yield $81 \mathrm{mg}(41 \%)$, $R_{\mathrm{f}} 0.21$ (1:9, EtOAc/hexanes). ${ }^{1} \mathrm{H}$ NMR $\left(500 \mathrm{MHz}, \mathrm{CDCl}_{3}\right) \delta 7.86(\mathrm{~d}, J=8.4 \mathrm{~Hz}, 2 \mathrm{H}), 7.81(\mathrm{~s}$, 1H), 7.40-7.36 (m, 4H), 7.30 (d, $J=8.4 \mathrm{~Hz}, 2 \mathrm{H}), 5.48$ (t, $J=2.5 \mathrm{~Hz}, 1 \mathrm{H}), 5.15(\mathrm{~s}, 1 \mathrm{H}), 4.46-4.40$ (m, 1H), 2.84-2.79 (m, 1H), 2.61-2.57 (m, 1H), 2.36 (t, J=7.5 Hz, 1H), 2.17-2.11 (m, 2H), 2.07$2.01(\mathrm{~m}, 3 \mathrm{H}), 1.89-1.82(\mathrm{~m}, 1 \mathrm{H}), 1.64-1.61(\mathrm{~m}, 1 \mathrm{H}), 1.58-1.49(\mathrm{~m}, 5 \mathrm{H}), 1.36-1.32(\mathrm{~m}, 2 \mathrm{H}), 1.31-$ $1.25(\mathrm{~m}, 7 \mathrm{H}), 1.15-1.07(\mathrm{~m}, 7 \mathrm{H}), 0.94(\mathrm{~d}, J=6.5 \mathrm{~Hz}, 3 \mathrm{H}), 0.89(\mathrm{~d}, J=2.3 \mathrm{~Hz}, 3 \mathrm{H}), 0.88(\mathrm{~d}, J=$ $2.3 \mathrm{~Hz}, 3 \mathrm{H}), 0.71(\mathrm{~s}, 3 \mathrm{H}) .{ }^{13} \mathrm{C} \mathrm{NMR}\left(126 \mathrm{MHz}, \mathrm{CDCl}_{3}\right) \delta 146.4,139.2,135.0,134.6,134.4,131.4$, 129.6, 129.2, 128.3, 126.7, 123.6, 119.3, 117.9, 61.2, 56.8, 56.3, 50.2, 42.5, 41.9, 39.8, 39.7, 39.6, 37.9, 36.9, 36.3, 35.9, 32.0, 31.9, 29.7, 29.5, 28.4, 28.1, 24.8, 24.4, 23.9, 22.9, 22.7, 21.2, 19.6, 18.9, 14.3, 12.0. IR (v cm c $\left.^{-1}\right) 2926$ (m), 2861 (m), 2254 (s), 1708 (m), 1600 (s). HRMS (CI) $\left.\left[\mathrm{C}_{43} \mathrm{H}_{55} \mathrm{ClN}_{4}+\mathrm{H}\right)^{+}\right]$calcd $=663.4194$, found $\mathrm{m} / \mathrm{z} 663.4191$.

\section{2-(4-Chlorophenyl)-2-(6-methoxypyridin-2-yl)acetonitrile (39)}


<smiles>COc1cccc(C(C#N)c2ccc(Cl)cc2)n1</smiles>

Viscous oil, yield $103 \mathrm{mg}(80 \%), R_{\mathrm{f}} 0.19$ (1:9, EtOAc/hexanes). ${ }^{1} \mathrm{H}$ NMR $\left(400 \mathrm{MHz}, \mathrm{CDCl}_{3}\right) \delta$ $7.44(\mathrm{dd}, J=8.4,7.2 \mathrm{~Hz}, 1 \mathrm{H}), 7.34-7.31(\mathrm{~m}, 2 \mathrm{H}), 7.27-7.25(\mathrm{~m}, 2 \mathrm{H}), 6.80(\mathrm{~d}, J=8.0 \mathrm{~Hz}, 1 \mathrm{H}), 6.57$ $(\mathrm{d}, J=8.0 \mathrm{~Hz}, 1 \mathrm{H}), 5.02(\mathrm{~s}, 1 \mathrm{H}), 3.81(\mathrm{~s}, 3 \mathrm{H}) .{ }^{13} \mathrm{C} \mathrm{NMR}\left(100 \mathrm{MHz}, \mathrm{CDCl}_{3}\right) \delta 164.1,152.2,139.8$, 134.5, 133.5, 129.3, 129.2, 118.8, 114.3, 110.8, 53.7, 44.52. IR (v cm$\left.{ }^{-1}\right) 3020(\mathrm{~s}), 2953(\mathrm{~m}), 2248$ $\left.(\mathrm{s}), 1601(\mathrm{~m}), 1575(\mathrm{~s}) . \mathrm{HRMS}(\mathrm{CI})\left[\mathrm{C}_{14} \mathrm{H}_{11} \mathrm{ClN}_{2} \mathrm{O}+\mathrm{H}\right)^{+}\right]$calcd $=259.0633$, found $\mathrm{m} / \mathrm{z} 259.0634$.

\section{2-(6-methoxypyridin-3-yl)-2-(4-(naphthalen-1-yl)phenyl)acetonitrile (42)}<smiles>COc1ccc(C(C#N)c2ccc(-c3cccc4ccccc34)cc2)cn1</smiles>

Viscous oil, yield $136 \mathrm{mg}(78 \%), R_{\mathrm{f}} 0.24$ (1:4, EtOAc/hexanes). ${ }^{1} \mathrm{H}$ NMR $\left(500 \mathrm{MHz}, \mathrm{CDCl}_{3}\right) \delta$ $8.24(\mathrm{~d}, J=2.5 \mathrm{~Hz}, 1 \mathrm{H}), 7.92-7.83(\mathrm{~m}, 3 \mathrm{H}), 7.63(\mathrm{dd}, J=8.6,2.6 \mathrm{~Hz}, 1 \mathrm{H}), 7.54-7.49$ (m, 4H), 7.49-7.42 (m, 3H), 7.39 (dd, $J=7.0,1.0 \mathrm{~Hz}, 1 \mathrm{H}), 6.82(\mathrm{~d}, J=8.7 \mathrm{~Hz}, 1 \mathrm{H}), 5.20(\mathrm{~s}, 1 \mathrm{H}), 3.97(\mathrm{~s}$, $3 \mathrm{H}) .{ }^{13} \mathrm{C} \mathrm{NMR}\left(126 \mathrm{MHz}, \mathrm{CDCl}_{3}\right) \delta 164.3,146.1,141.2,139.1,138.1,134.3,133.9,131.5,131.1$, $128.5,128.2$, 127.6, 127.1, 126.4, 126.1, 125.8, 125.5, 124.8, 119.3, 111.9, 53.8, 39.5. IR $\left(v^{-1}\right)$ $3018(\mathrm{~m}), 2984(\mathrm{~m}), 2251$ (s), 1607 (s), 1572 (s). HRMS (EI) $\left.\left[\mathrm{C}_{24} \mathrm{H}_{18} \mathrm{~N}_{2} \mathrm{O}\right)^{+}\right]$calcd = 350.1419, found $\mathrm{m} / \mathrm{z} 350.1414$.

(4-Chlorophenyl)(6-methoxypyridin-3-yl)methanone (43) (CAS No : $\underline{\text { 1652600-64-0) }}$<smiles>COc1ccc(C(=O)c2ccc(Cl)cc2)cn1</smiles>

White solid, yield $96 \mathrm{mg}$ (78\%), $R_{\mathrm{f}} 0.23$ (1:9, EtOAc/hexanes). ${ }^{1} \mathrm{H} \mathrm{NMR}\left(500 \mathrm{MHz}, \mathrm{CDCl}_{3}\right) \delta 8.58$ $(\mathrm{s}, 1 \mathrm{H}), 8.07(\mathrm{dd}, J=8.7,2.4 \mathrm{~Hz}, 1 \mathrm{H}), 7.74-7.72(\mathrm{~m}, 2 \mathrm{H}), 7.48-7.46(\mathrm{~m}, 2 \mathrm{H}), 6.84(\mathrm{dd}, J=8.7,0.6$ $\mathrm{Hz}, 1 \mathrm{H}), 4.02(\mathrm{~s}, 3 \mathrm{H}) .{ }^{13} \mathrm{C} \mathrm{NMR}\left(126 \mathrm{MHz}, \mathrm{CDCl}_{3}\right) \delta 193.0,166.7,150.8,140.0,139.1,135.9$, $131.2,128.9,126.8,111.4,110.1,54.3$.

(1-Benzyl-1H-indol-5-yl)(4-chlorophenyl)methanone (44) 


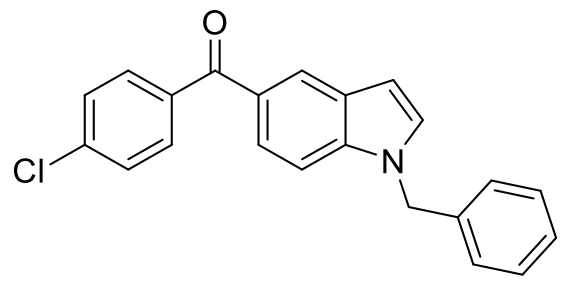

Viscous oil, yield $140 \mathrm{mg}(73 \%), R_{\mathrm{f}} 0.23$ (1:19, EtOAc/hexanes). ${ }^{1} \mathrm{H}$ NMR (400 MHz, $\left.\mathrm{CDCl}_{3}\right) \delta$ $8.08(\mathrm{~s}, 1 \mathrm{H}), 7.86(\mathrm{~d}, J=8.0 \mathrm{~Hz}, 2 \mathrm{H}), 7.79-7.73(\mathrm{~m}, 3 \mathrm{H}), 7.38-7.29(\mathrm{~m}, 4 \mathrm{H}), 7.24(\mathrm{~d}, J=2.7 \mathrm{~Hz}$, $1 \mathrm{H}), 7.13(\mathrm{~d}, J=6.9 \mathrm{~Hz}, 2 \mathrm{H}), 6.67(\mathrm{~d}, J=2.8 \mathrm{~Hz}, 1 \mathrm{H}), 5.38(\mathrm{~s}, 2 \mathrm{H}) .{ }^{13} \mathrm{C} \mathrm{NMR}\left(100 \mathrm{MHz}, \mathrm{CDCl}_{3}\right)$ $\delta$ 195.4, 143.0, 139.1, 136.7, 132.1, 130.4, 130.2, 129.1, 128.2, 128.1, 126.9, 125.8, 123.9, 118.4, 114.9, 110.1, 103.9, 50.5. IR ( $\left.\mathrm{v} \mathrm{cm}^{-1}\right) 3021$ (s), 2952 (m), 1690 (s), 1605 (m), 1567 (s). HRMS $\left[\mathrm{C}_{22} \mathrm{H}_{16} \mathrm{ClNO}\right]^{+}$calcd. 345.0920, found $(\mathrm{m} / \mathrm{z}) 345.0918$.

(4-((5-(4-Chlorobenzoyl)-1H-indol-1-yl)methyl)phenyl)(4-chlorophenyl)methanone (45)

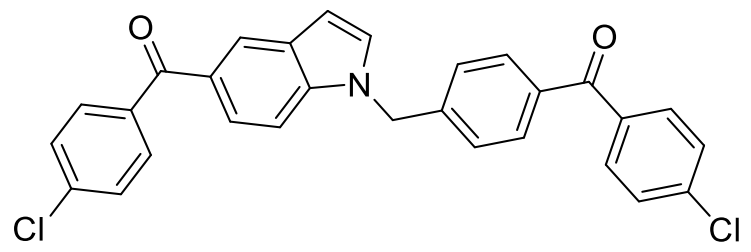

Viscous oil, yield $157 \mathrm{mg}$ (65\%), $R_{\mathrm{f}} 0.24$ (1:9, EtOAc/hexanes). ${ }^{1} \mathrm{H}$ NMR (400 MHz, $\left.\mathrm{CDCl}_{3}\right) \delta$ 8.12 (s, 1H), 7.77-7.70 (m, 7H), 7.45 (t, $J=8.0 \mathrm{~Hz}, 4 \mathrm{H}), 7.34$ (d, $J=8.4 \mathrm{~Hz}, 1 \mathrm{H}), 7.27(\mathrm{~s}, 1 \mathrm{H})$, $7.21(\mathrm{~d}, J=7.6 \mathrm{~Hz}, 2 \mathrm{H}), 6.70(\mathrm{~d}, J=2.3 \mathrm{~Hz}, 1 \mathrm{H}), 5.46(\mathrm{~s}, 2 \mathrm{H}) .{ }^{13} \mathrm{C} \mathrm{NMR}\left(100 \mathrm{MHz}, \mathrm{CDCl}_{3}\right) \delta$ 195.8, 194.8, 141.8, 139.2, 138.7, 138.1, 137.2, 136.9, 135.7, 131.4, 130.7, 130.4, 130.1, 129.5, 128.8, 128.5, 128.1, 126.7, 125.5, 124.2, 109.7, 104.2, 50.1. IR (v cm$\left.{ }^{-1}\right) 3030(\mathrm{~s}), 2955$ (m), 1705 (s), $1610(\mathrm{~m}), 1559$ (s). MALDI-TOF MS $\left[\mathrm{C}_{29} \mathrm{H}_{19} \mathrm{Cl}_{2} \mathrm{NO}_{2}+\mathrm{H}\right]+$ calcd. 484.087, found $(\mathrm{m} / \mathrm{z})$ 484.089 .

\section{1-(3,5-Bis(trifluoromethyl)phenyl)-5-methoxy-1H-indole ${ }^{8}$}<smiles>COc1ccc2c(ccn2-c2cc(C(F)(F)F)cc(C(F)(F)F)c2)c1</smiles> 
White solid, yield $71.8 \mathrm{mg}(80 \%), R_{\mathrm{f}} 0.4$ (4:1, hexanes/ethyl acetate). ${ }^{1} \mathrm{H}$ NMR (500 $\left.\mathrm{MHz}, \mathrm{CDCl}_{3}\right)$ : $\delta 7.96(\mathrm{~s}, 2 \mathrm{H}), 7.82(\mathrm{~s}, 1 \mathrm{H}), 7.44(\mathrm{~d}, J=10 \mathrm{~Hz}, 1 \mathrm{H}), 7.33$ (d, $J=5 \mathrm{~Hz}, 1 \mathrm{H}), 7.16(\mathrm{~d}, J=5 \mathrm{~Hz}, 1 \mathrm{H})$, $6.95(\mathrm{dd}, J=5 \mathrm{~Hz}, 10 \mathrm{~Hz}, 1 \mathrm{H}), 6.70(\mathrm{dd}, J=0.5 \mathrm{~Hz}, 3 \mathrm{~Hz}, 1 \mathrm{H}), 3.89$ (s, 3H); ${ }^{19} \mathrm{~F} \mathrm{NMR}(376 \mathrm{MHz}$, $\left.\mathrm{CDCl}_{3}\right):-63.24$.

\section{REFERENCES}

(1) Fulmer, G. R.; Miller, A. J. M.; Sherden, N. H.; Gottlieb, H. E.; Nudelman, A.; Stoltz, B. M.; Bercaw, J. E.; Goldberg, K. I. NMR Chemical Shifts of Trace Impurities: Common Laboratory Solvents, Organics, and Gases in Deuterated Solvents Relevant to the Organometallic Chemist. Organometallics 2010, 29, 2176-2179.

(2) Brals, J.; Smith, J. D.; Ibrahim, F.; Gallou, F.; Handa, S. Micelle-Enabled Palladium Catalysis for Convenient $\mathrm{Sp}^{2}-\mathrm{Sp}^{3}$ Coupling of Nitroalkanes with Aryl Bromides in Water Under Mild Conditions. ACS Catal. 2017, 7, 7245-7250.

(3) Horn, A.; Dussault, P. H. Synthesis of $\alpha$-Cyano and $\alpha$-Sulfonyl Cyclic Ethers via Intramolecular Reactions of Peroxides with Sulfone- and Nitrile-Stabilized Carbanions. J. Org. Chem. 2019, 84, 14611-14626.

(4) Chan, C. K.; Chang, M. Y. BF3·OEt2-Mediated [1,2]-Aryl Shift: Synthesis of Functionalized $\alpha$-Arylnitriles via the Bromination/Cyanation/Deformylation of Substituted Deoxybenzoin. Tetrahedron 2017, 73, 5207-5213.

(5) Kangani, C. O.; Day, B. W.; Kelley, D. E. Controlled Conversion of Phenylacetic Acids to Phenylacetonitriles or Benzonitriles Using Bis(2-Methoxyethyl)Aminosulfur Trifluoride. Tetrahedron Lett. 2008, 49, 914-918.

(6) Wang, J.; Masui, Y.; Onaka, M. Direct Synthesis of Nitriles from Alcohols with Trialkylsilyl Cyanide Using Brønsted Acid Montmorillonite Catalysts. ACS Catal. 2011, 1, 446-454.

(7) Nambo, M.; Yar, M.; Smith, J. D.; Crudden, C. M. The Concise Synthesis of Unsymmetric Triarylacetonitriles via Pd-Catalyzed Sequential Arylation: A New Synthetic Approach to Tri- and Tetraarylmethanes. Org. Lett. 2015, 17, 50-53.

(8) Ansari, T. N.; Taussat, A.; Clark, A. H.; Nachtegaal, M.; Plummer, S.; Gallou, F.; Handa, S. Insights on Bimetallic Micellar Nanocatalysis for Buchwald-Hartwig Aminations. ACS Catal. 2019, 9, 10389-10397. 


\section{NMR SPECTRA}

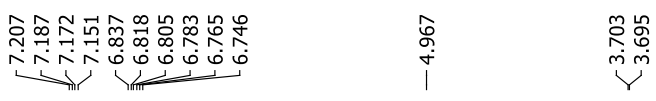<smiles>COc1ccc(C(C#N)c2cccc(OC)c2)cc1</smiles>
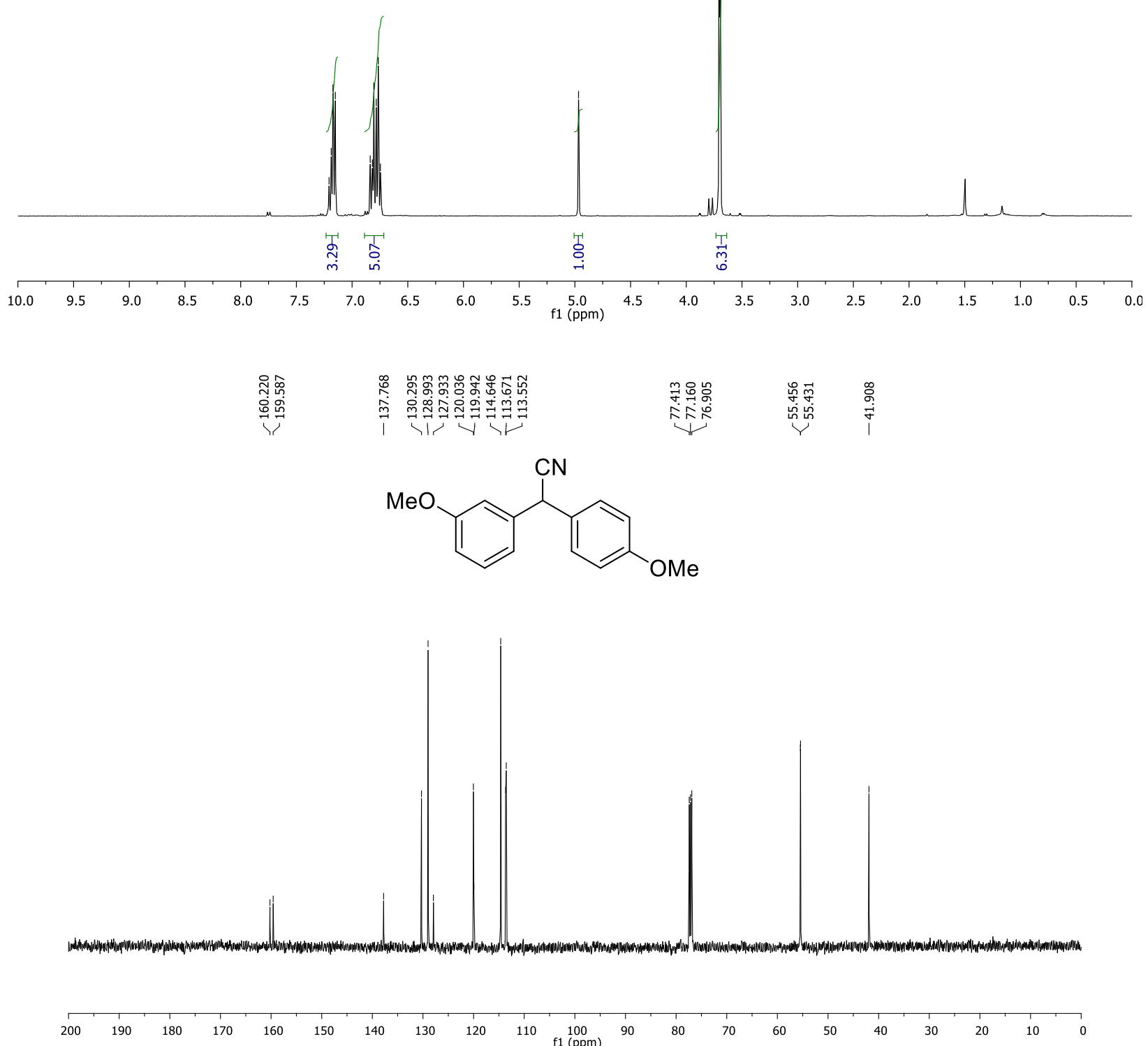


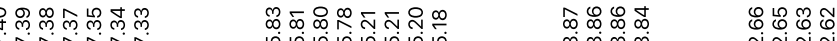

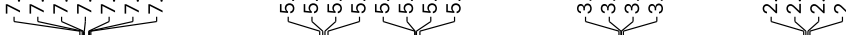<smiles>C=CCC(C#N)c1ccccc1</smiles>
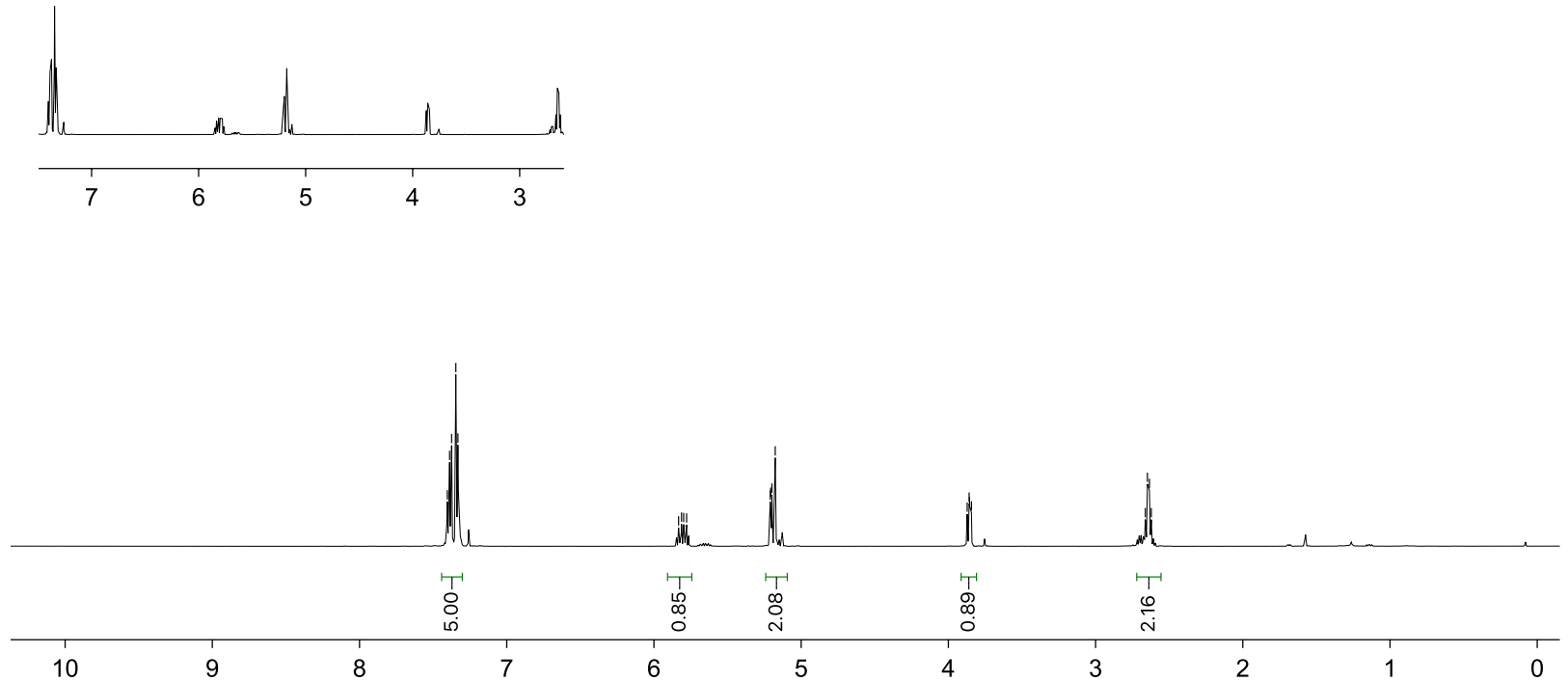

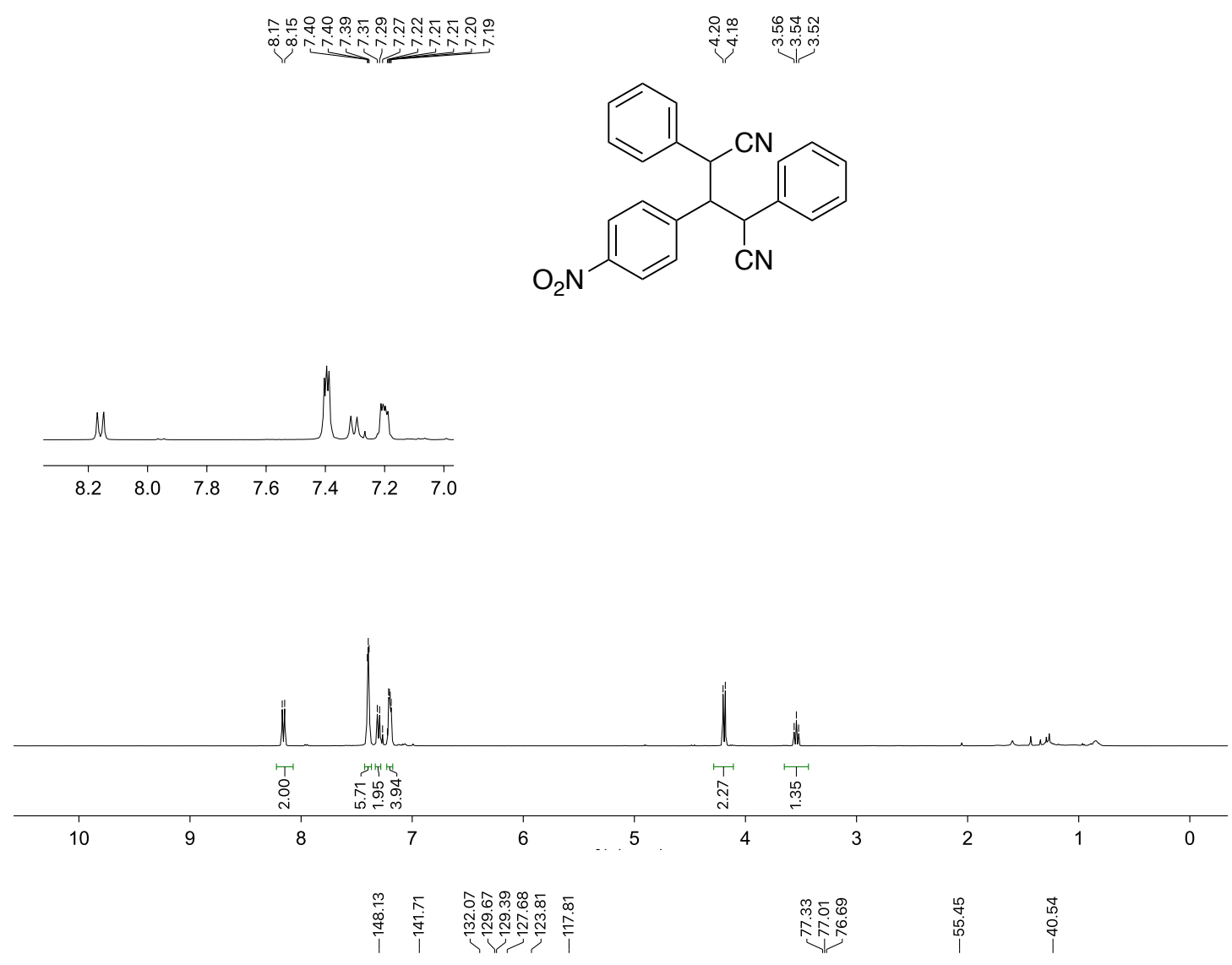<smiles>CC(c1ccccc1)C(c1ccc([N+](=O)[O-])cc1)C(C#N)c1ccccc1</smiles>

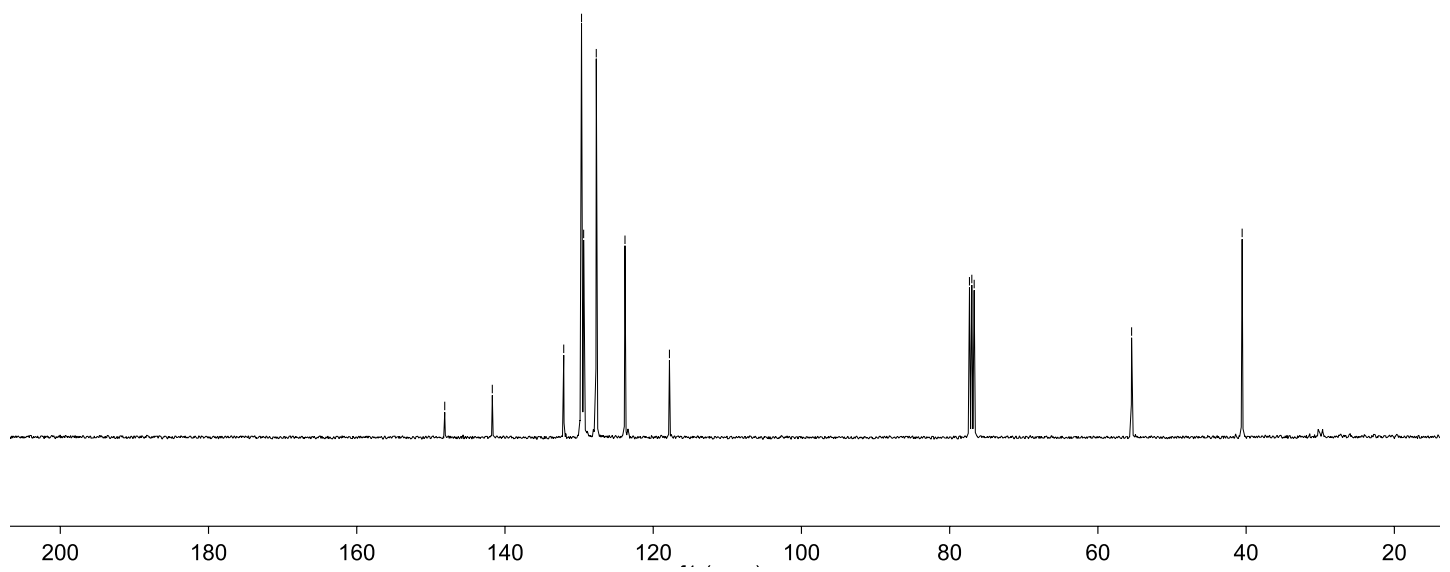




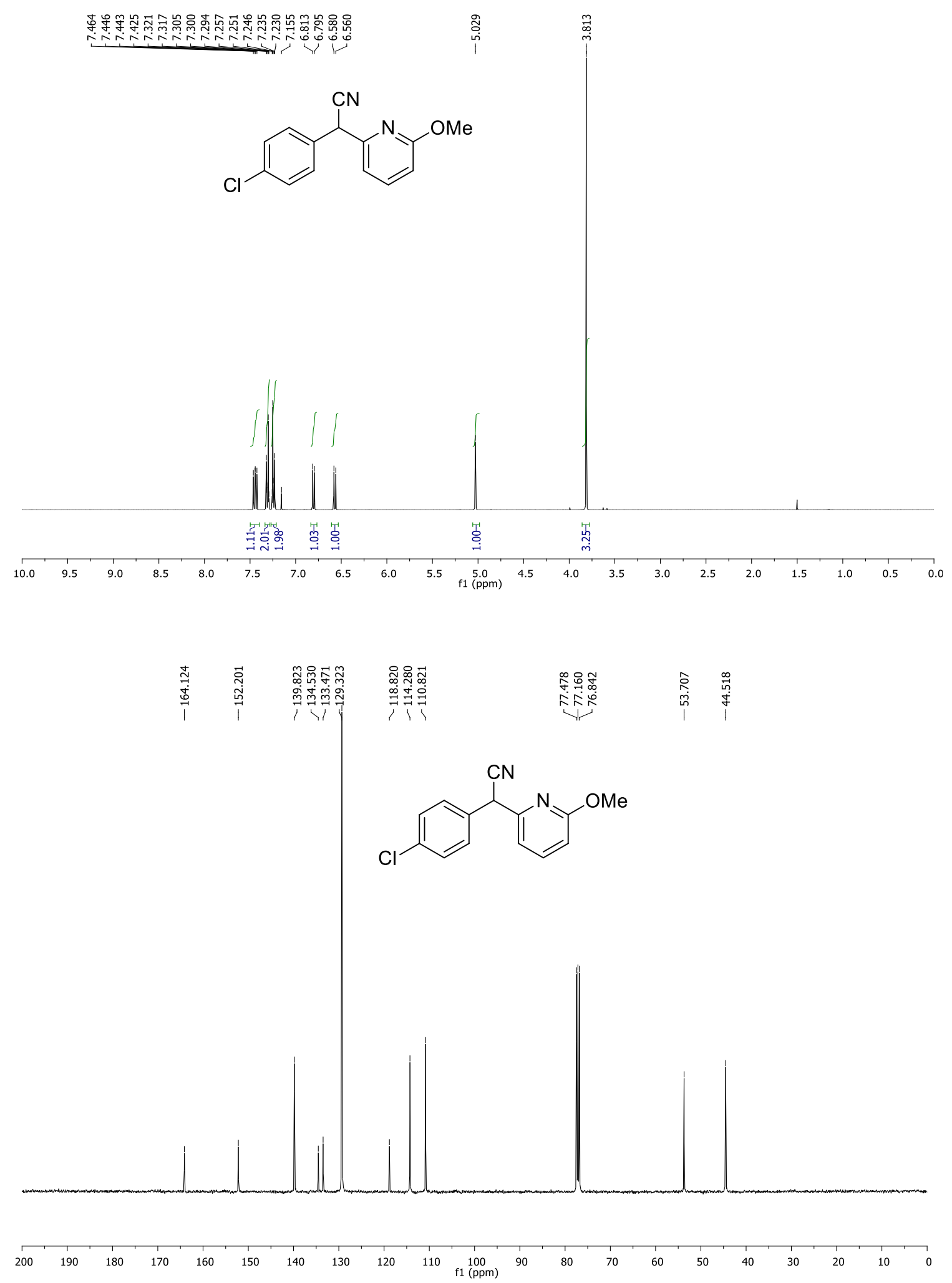




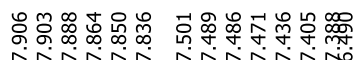

nNñ Ninisio<smiles>N#CC(c1cccc2ccccc12)c1cccc2ccccc12</smiles>

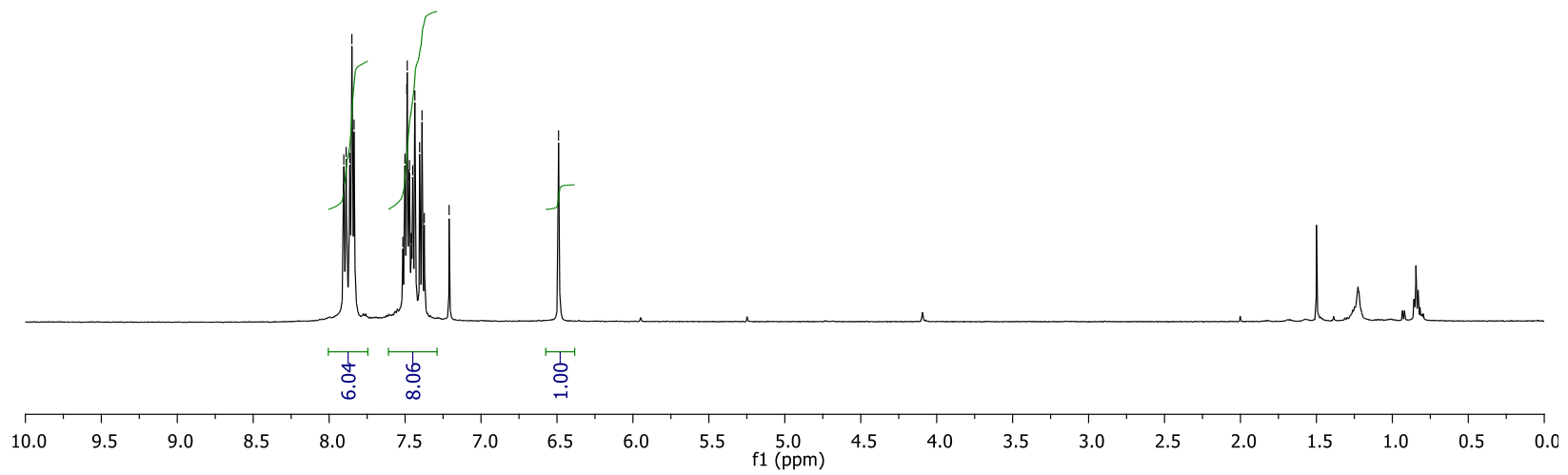



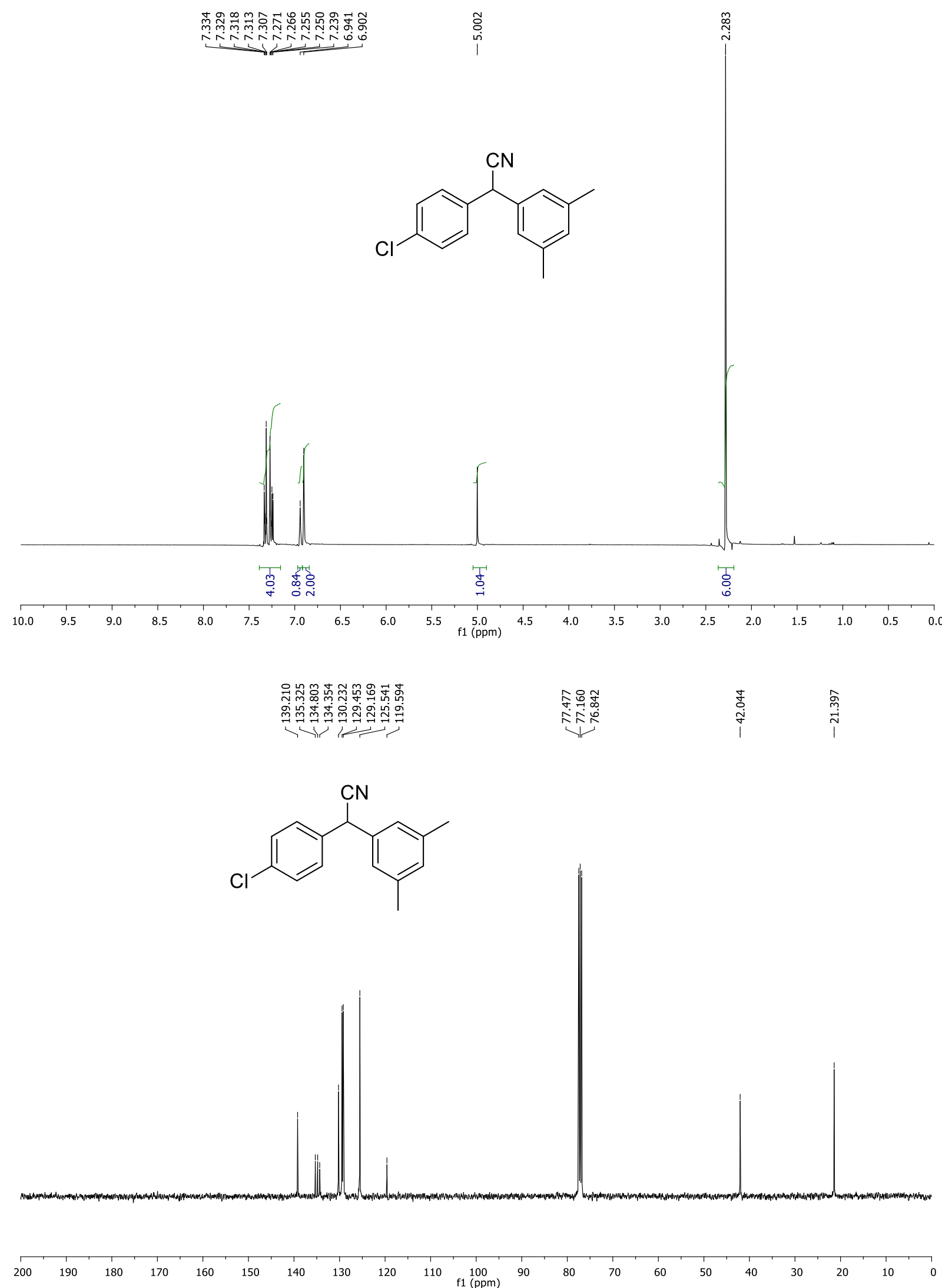


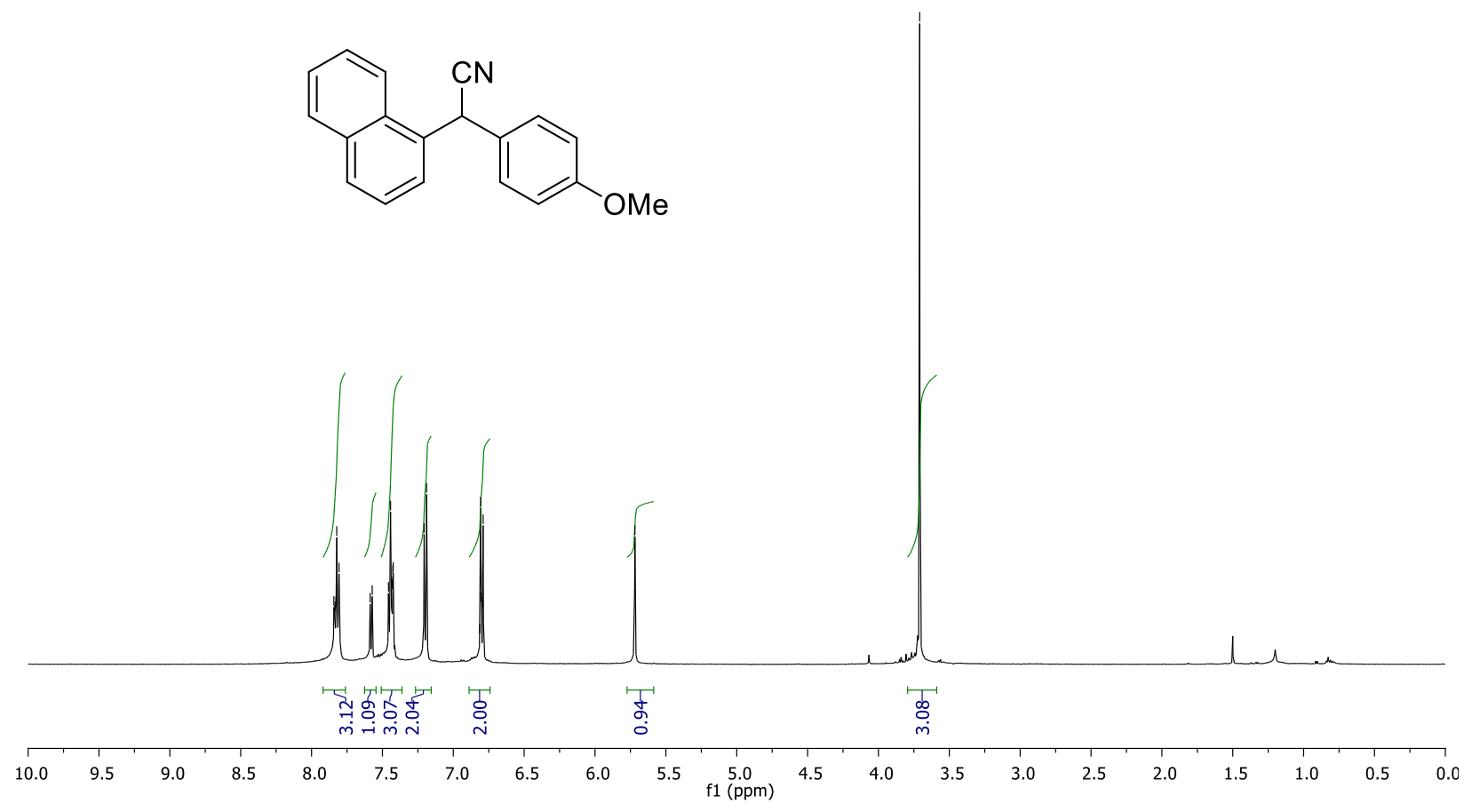




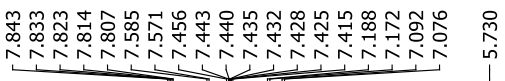

$\stackrel{\stackrel{\leftrightarrow}{N}}{i}$<smiles>Cc1ccc(C(C#N)c2cccc3ccccc23)cc1</smiles>

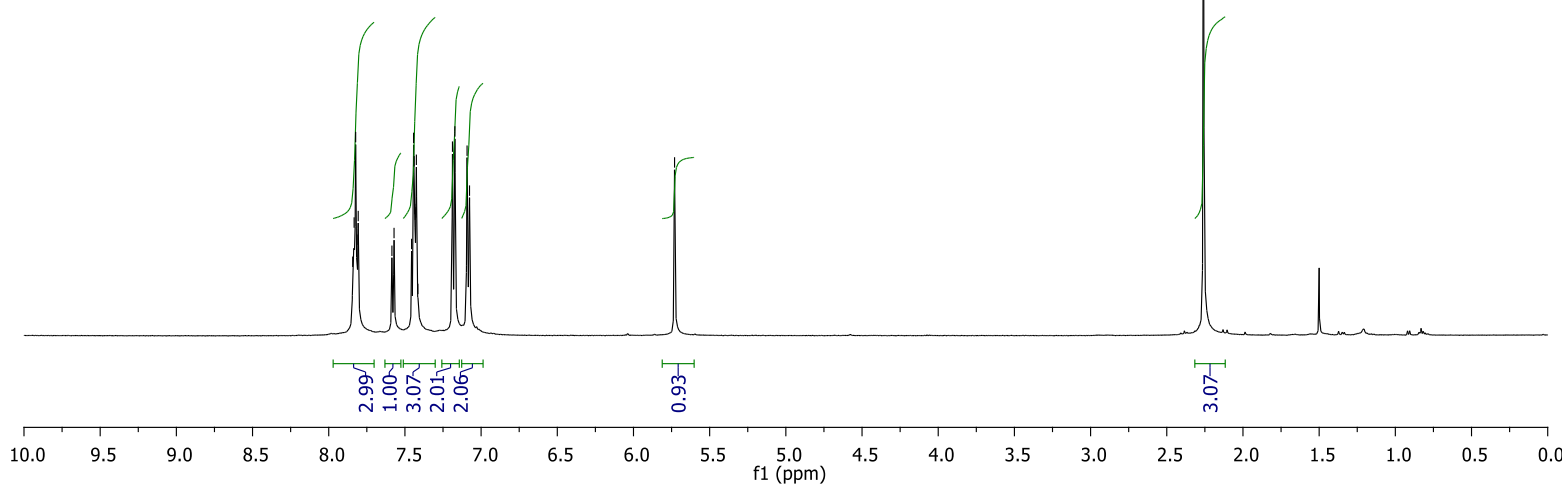

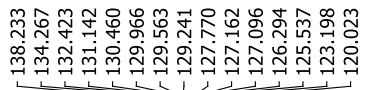

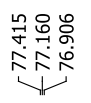

葛
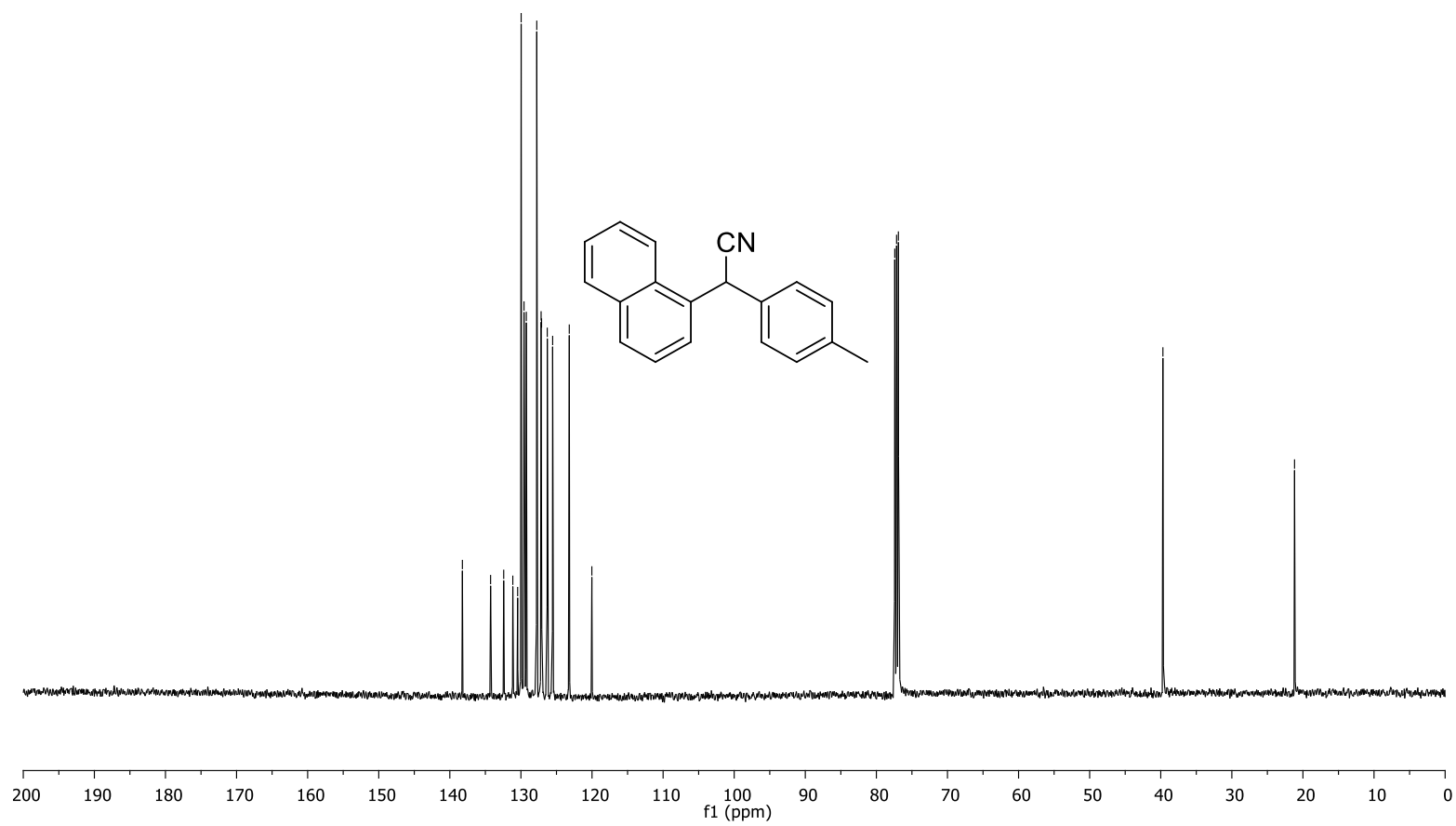

S43 

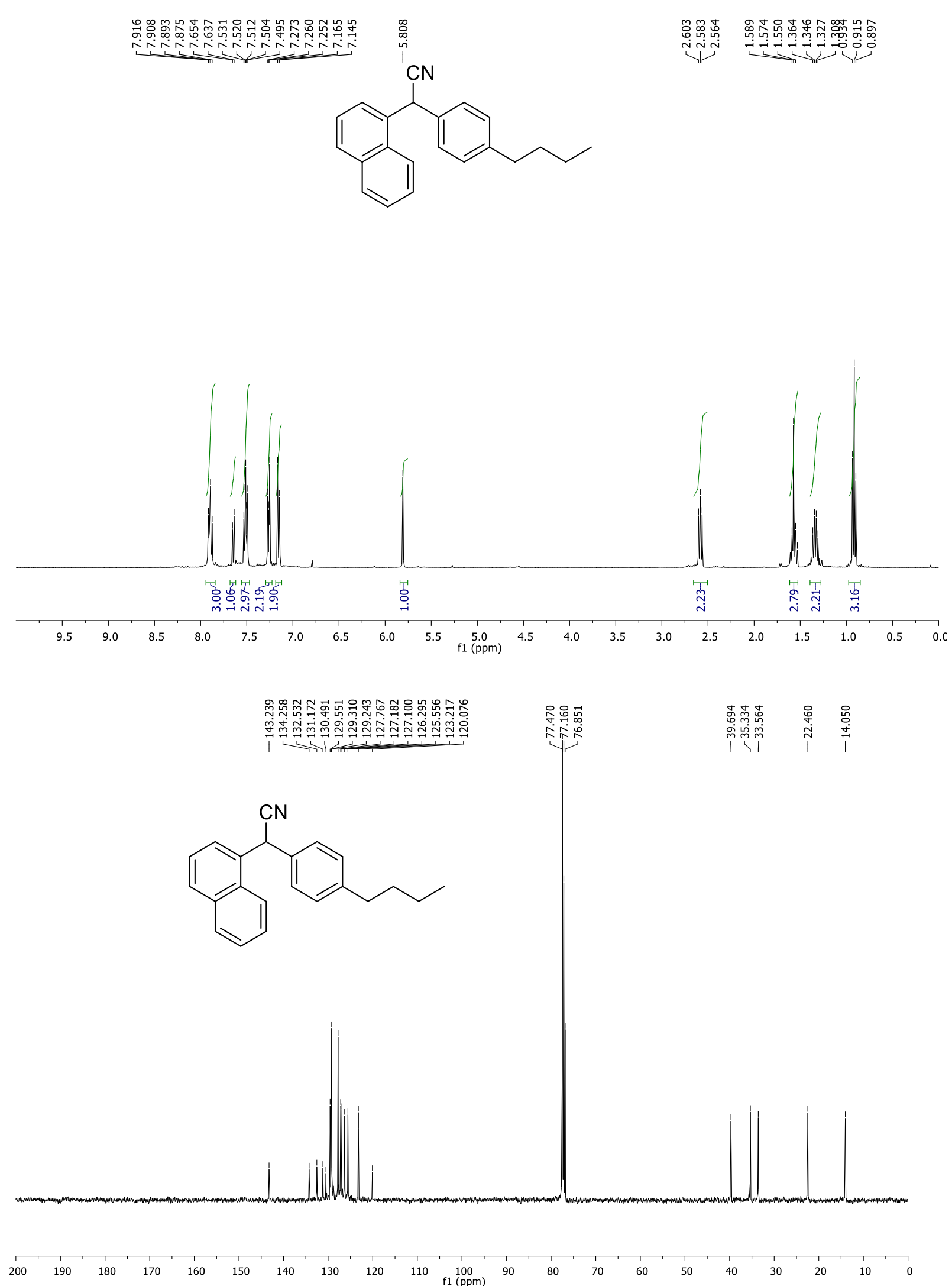

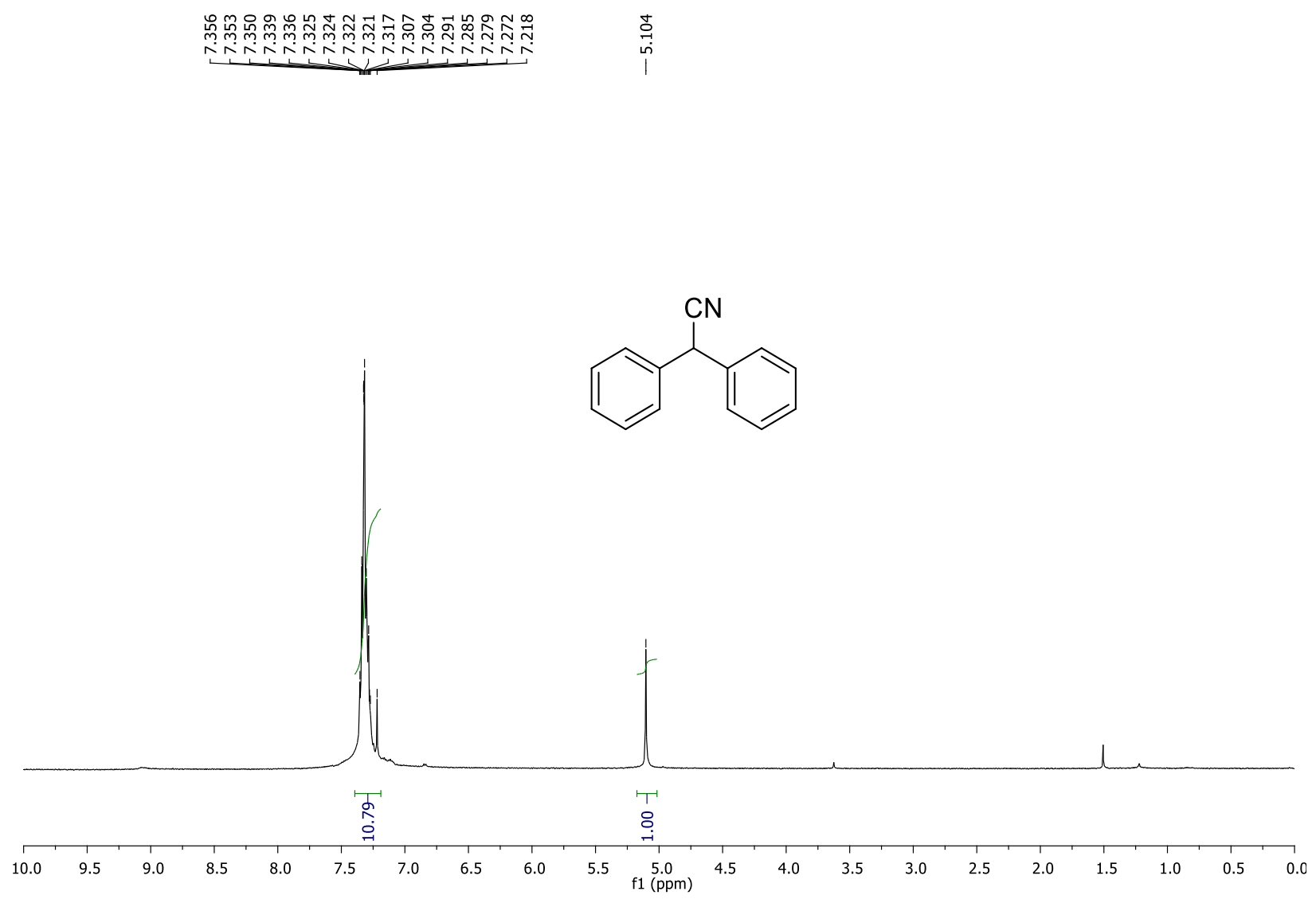


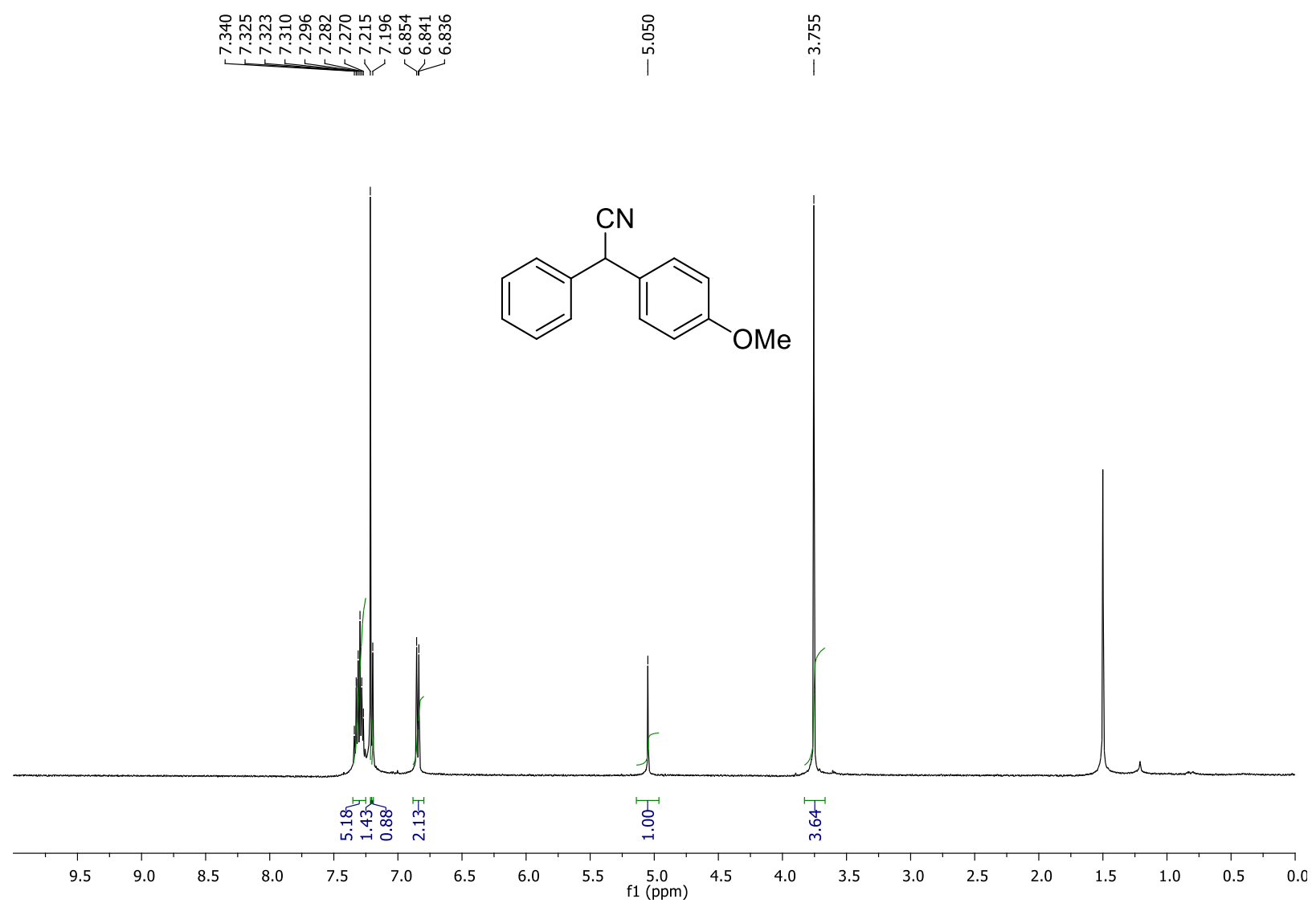



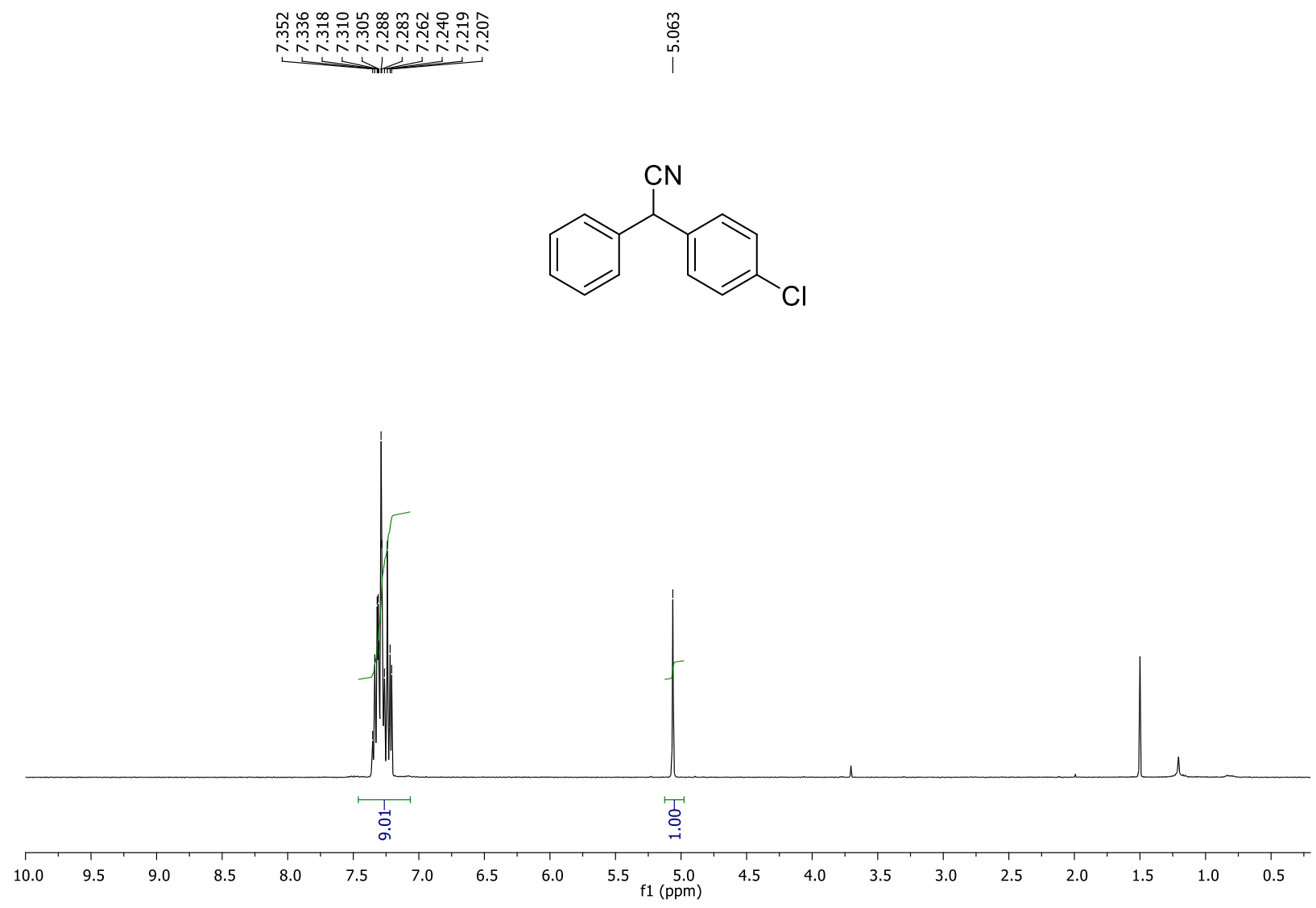


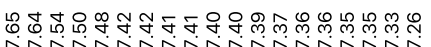
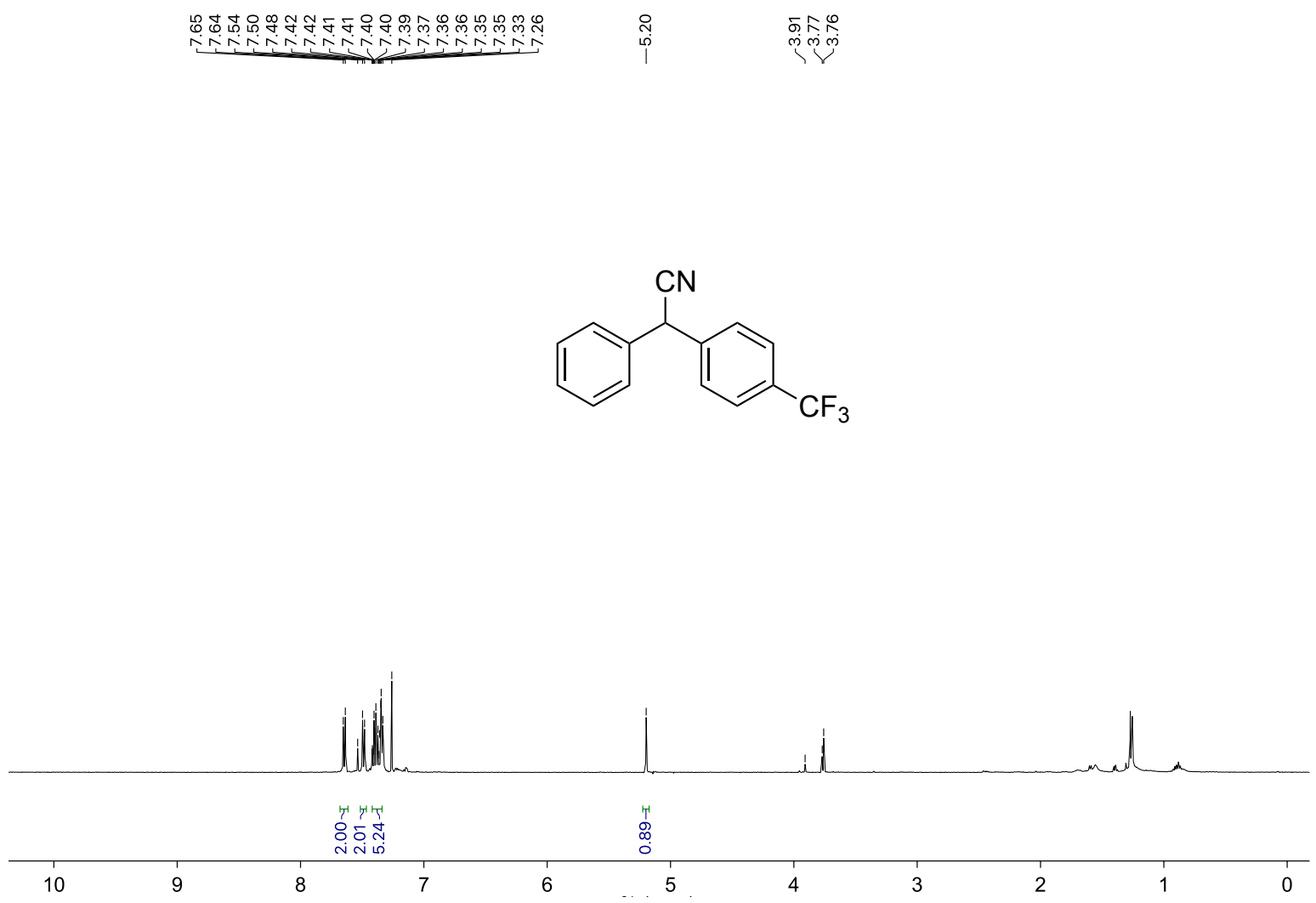

오ำ
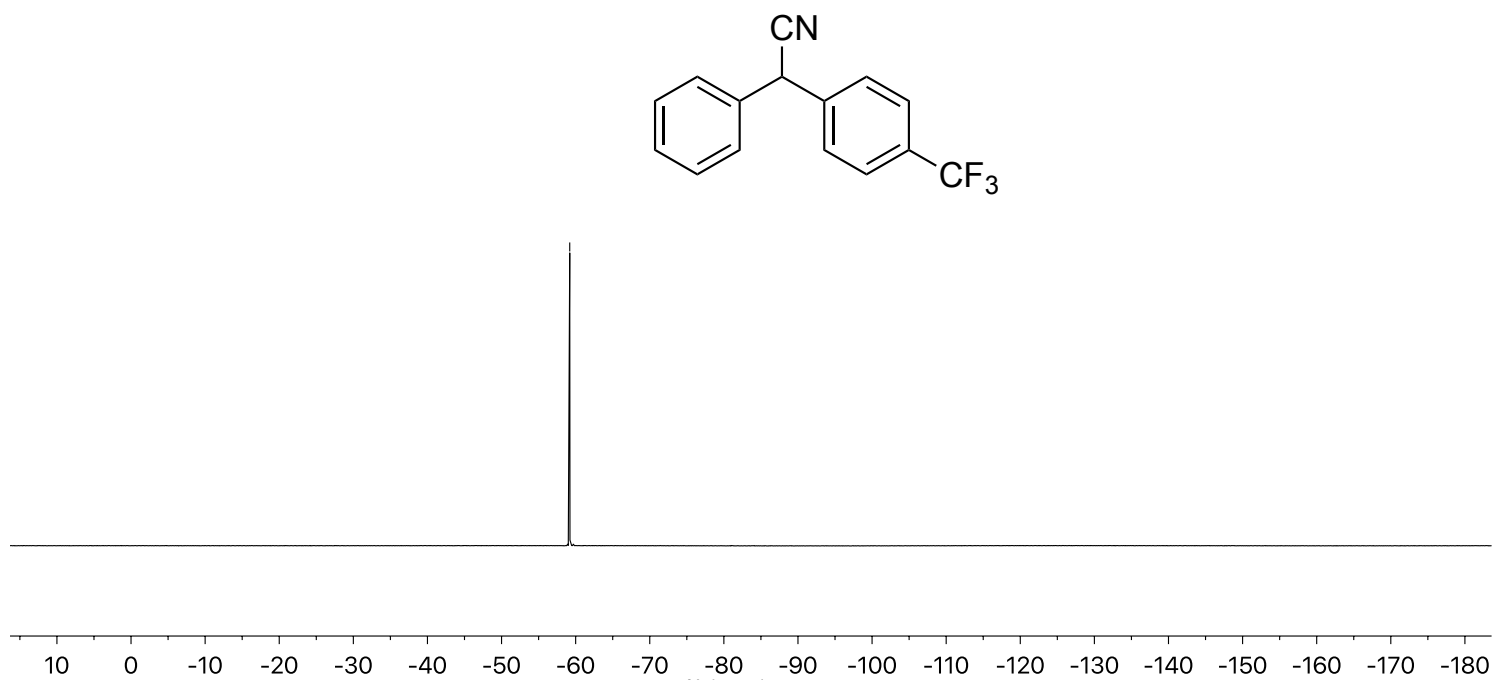

S48 


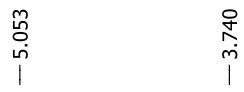

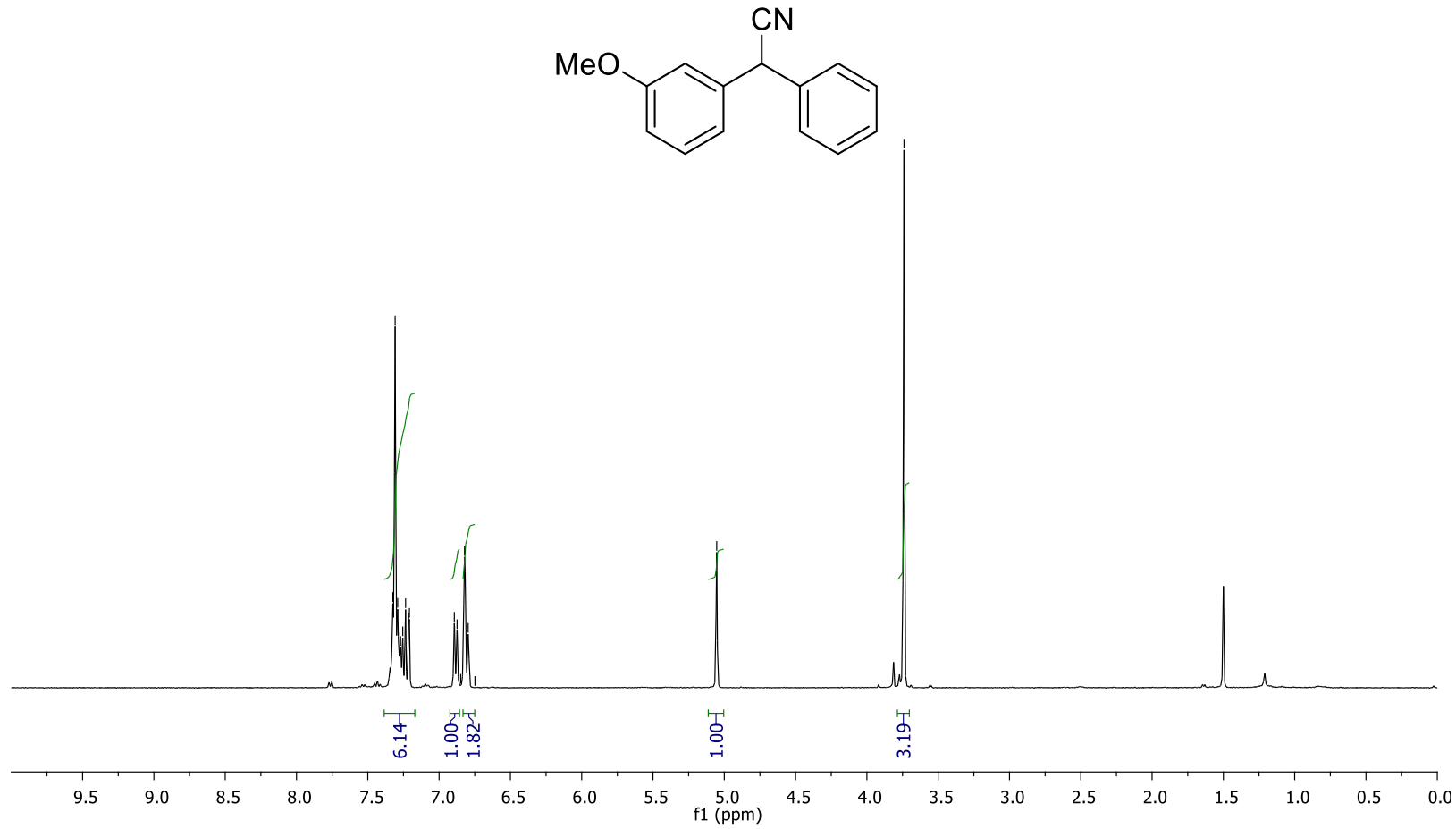




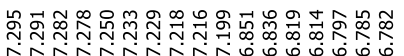

룽

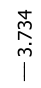
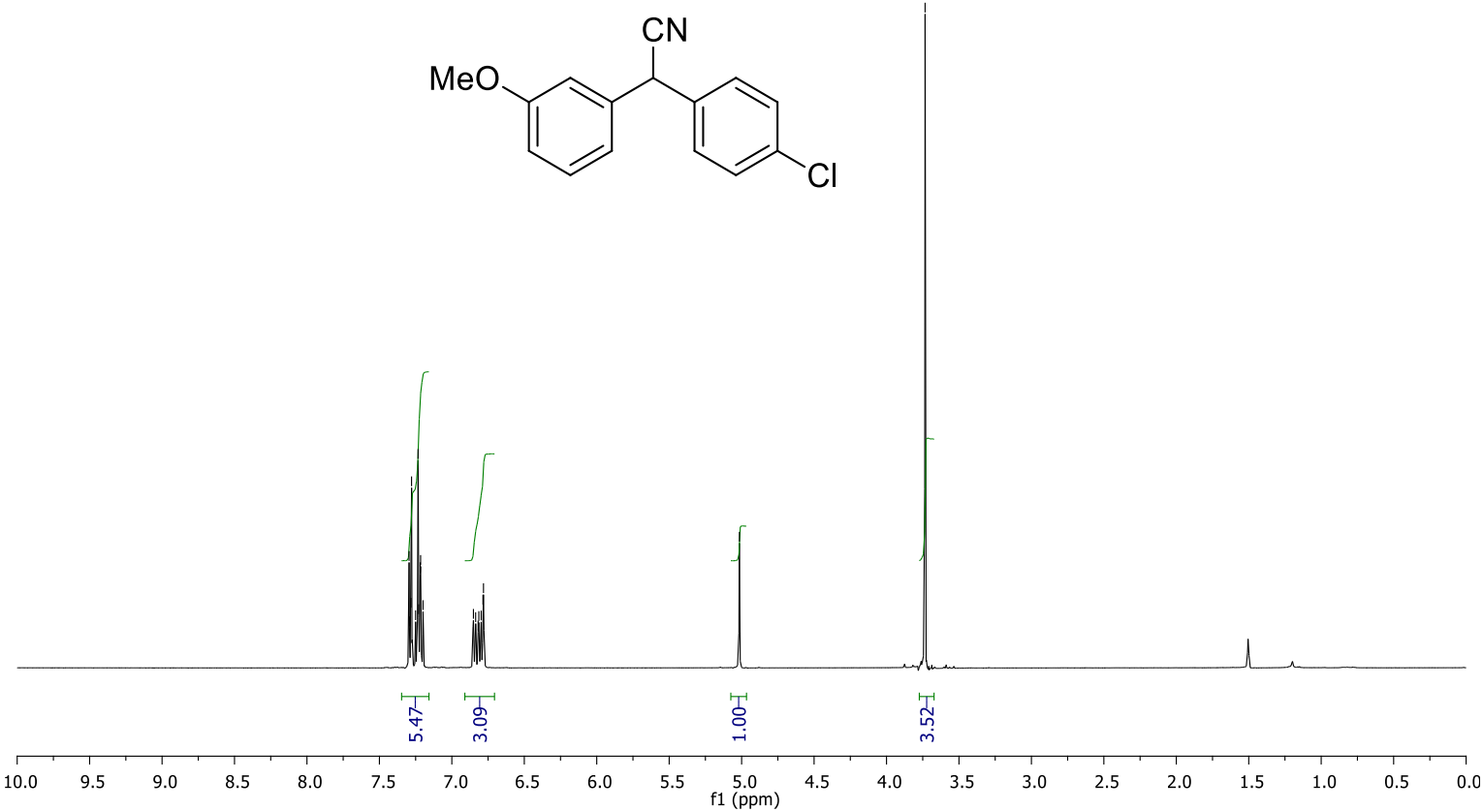

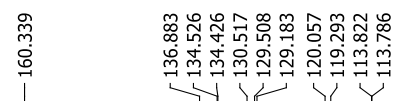

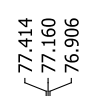

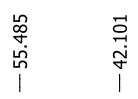
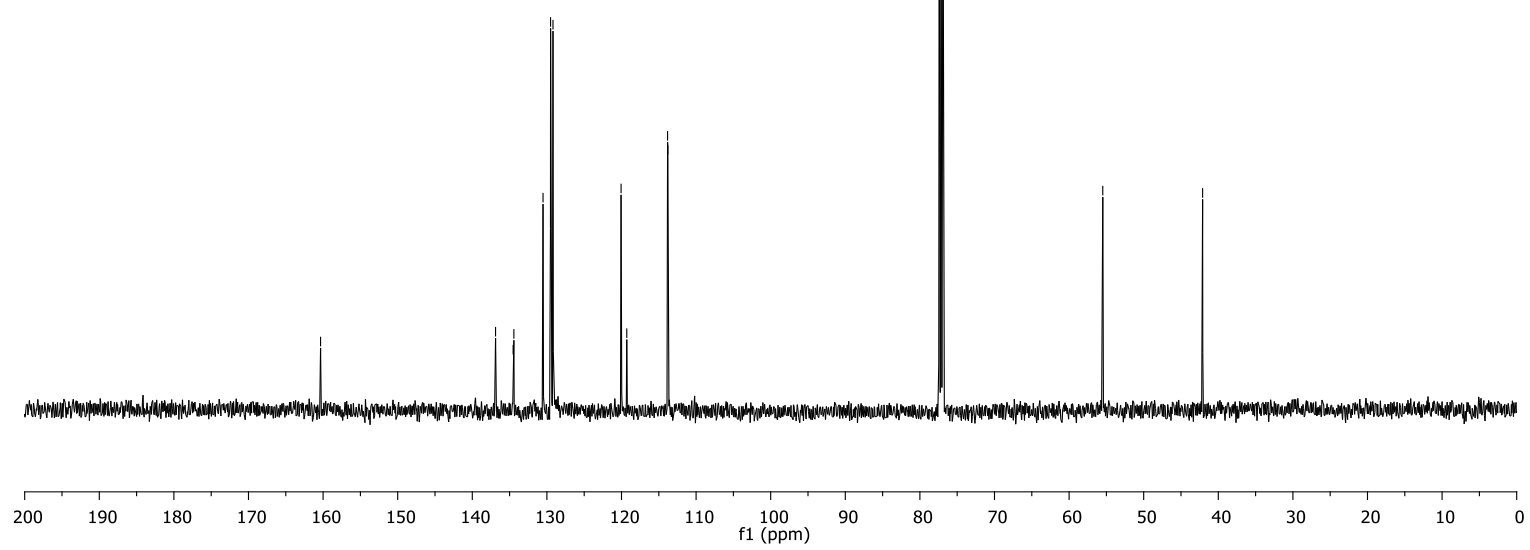

S50 


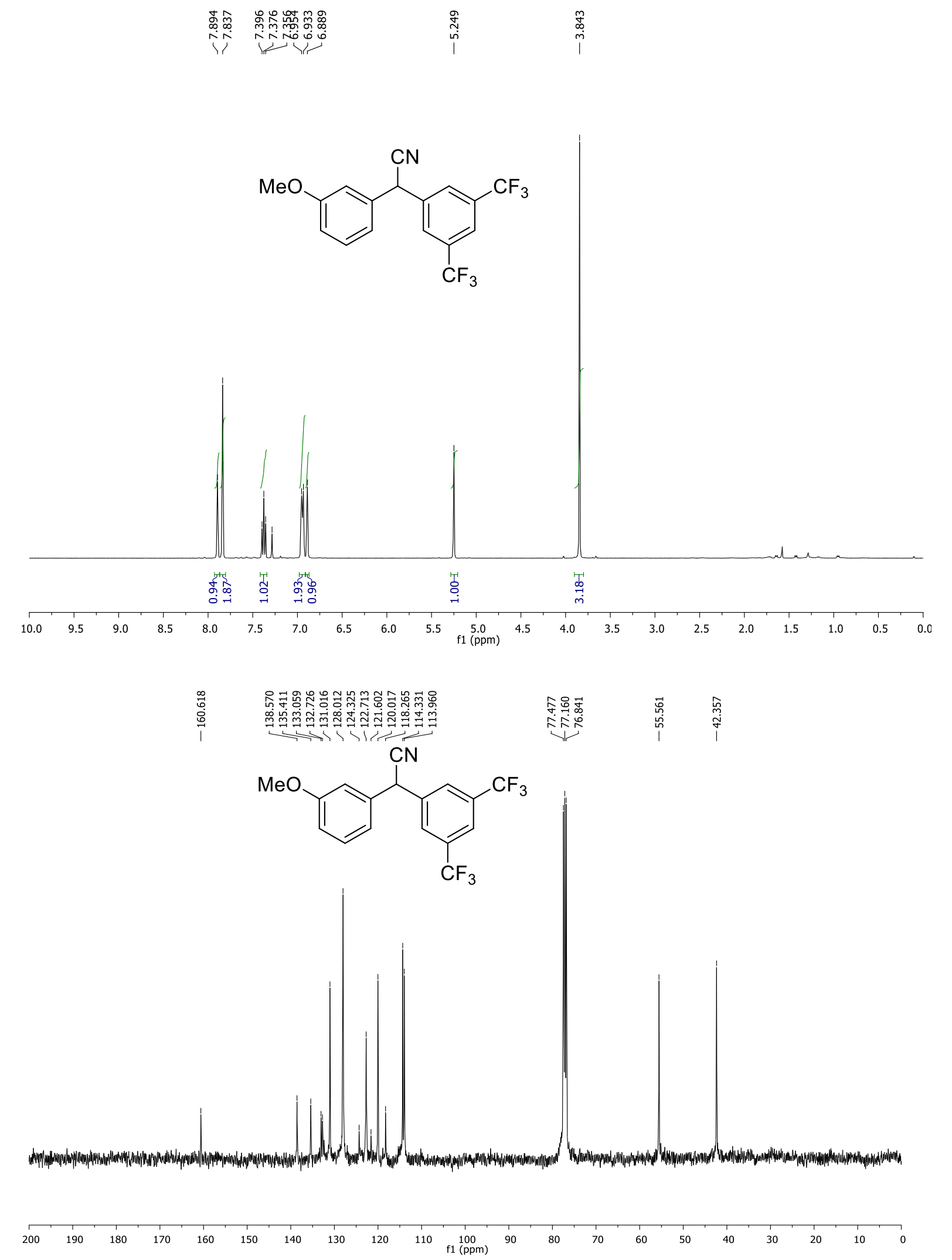




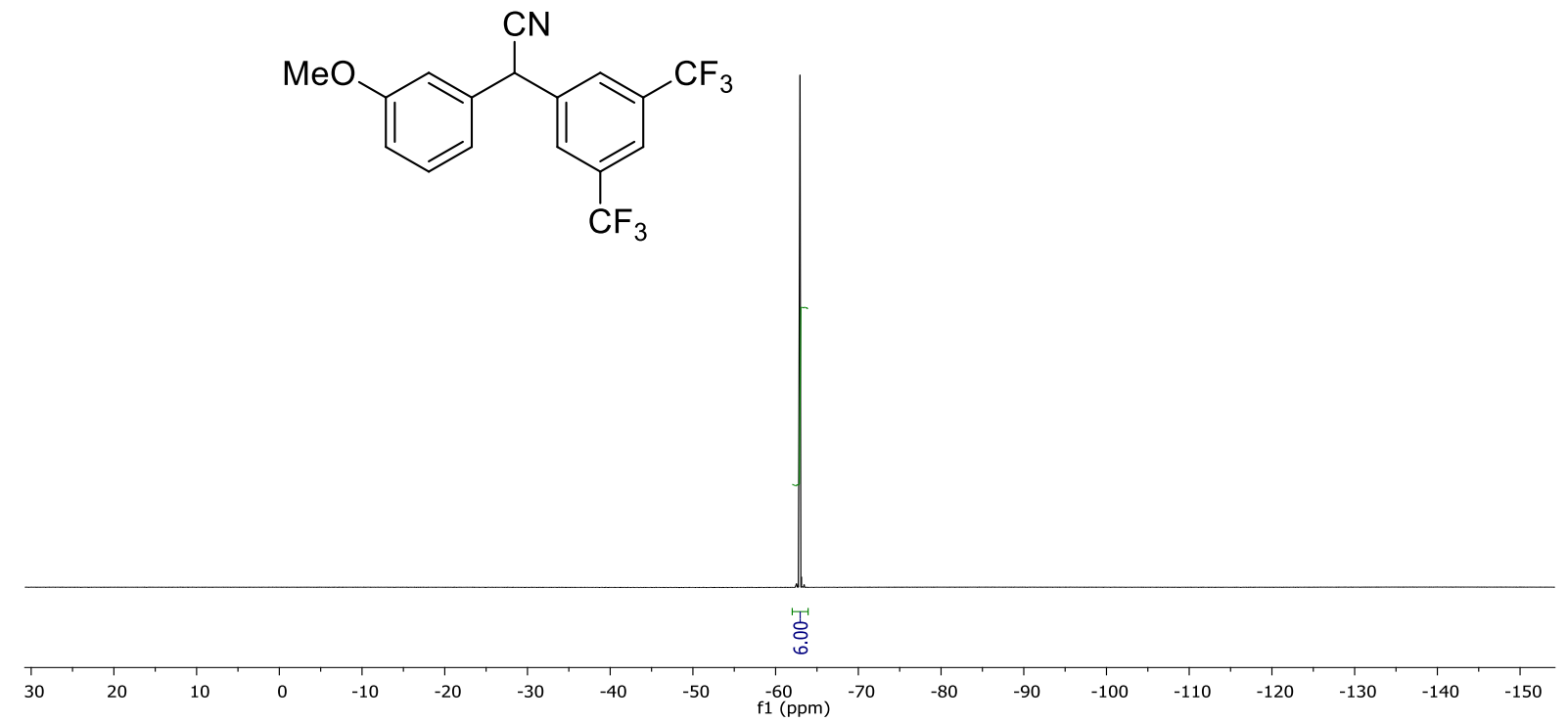



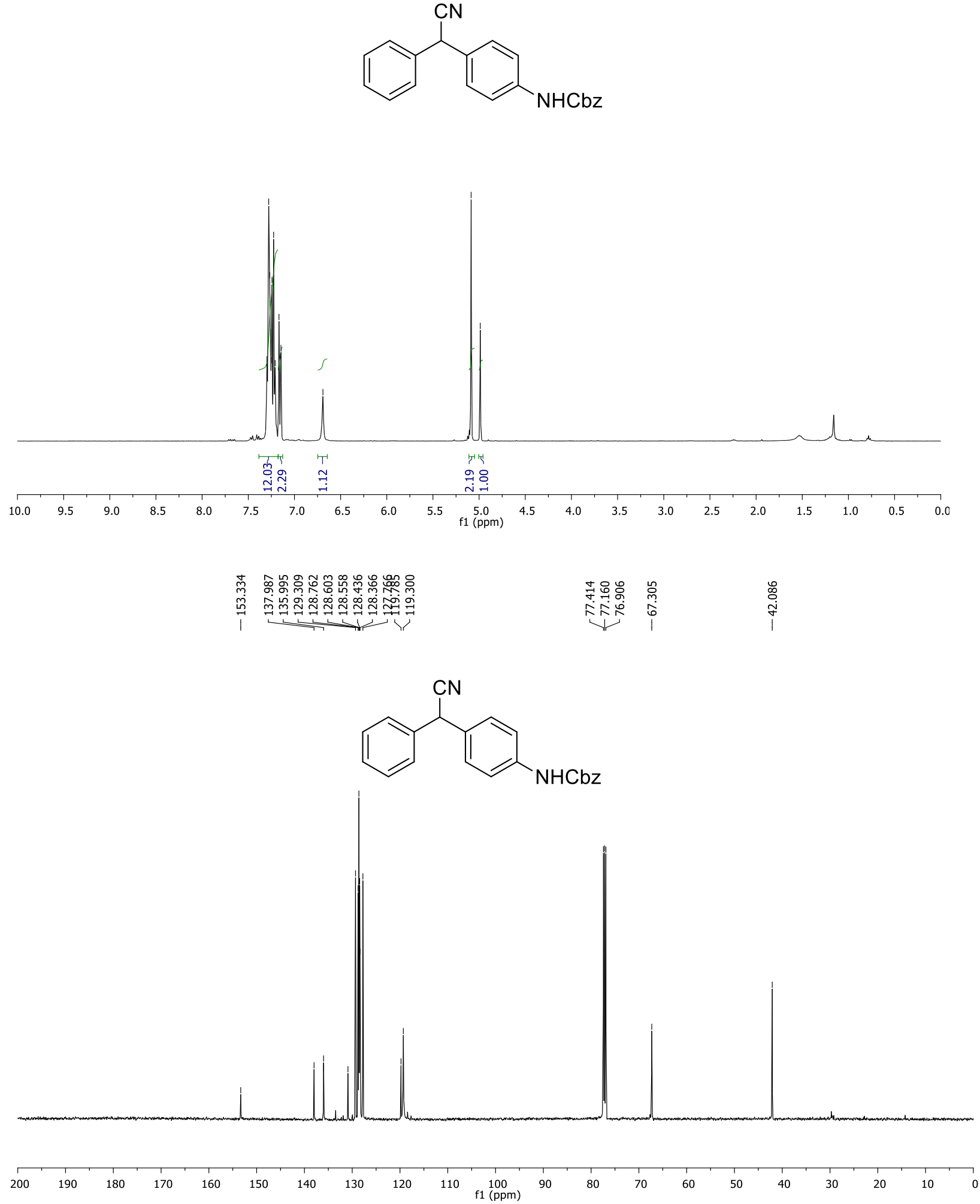


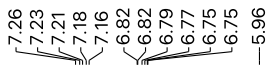

i.

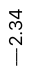
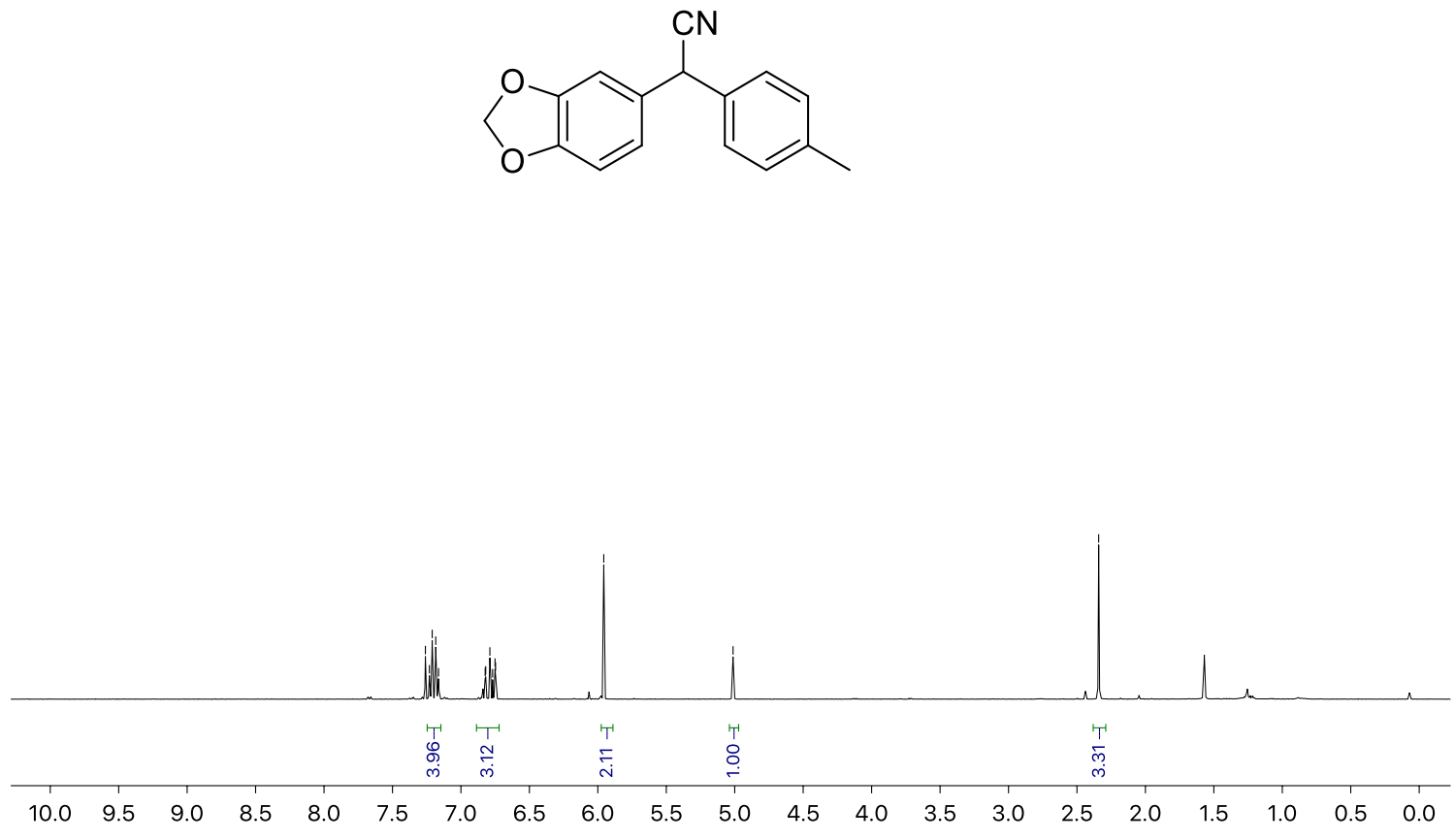

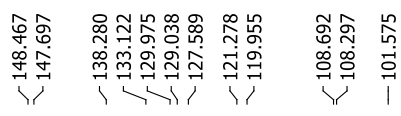

产

i⿱艹

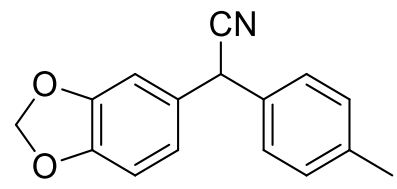

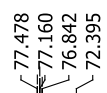

.
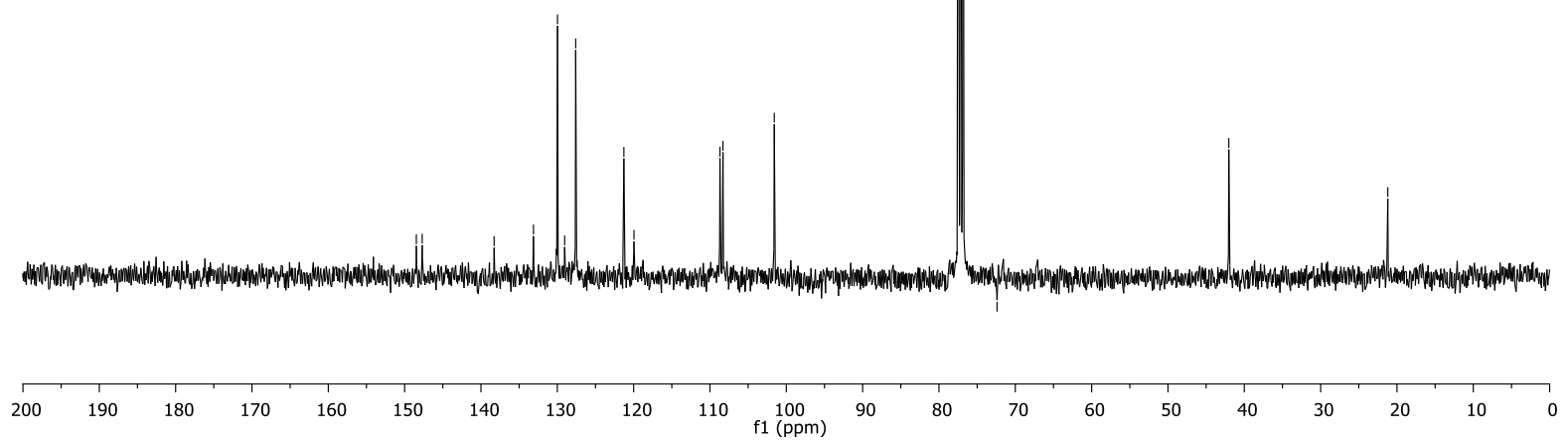

S54 


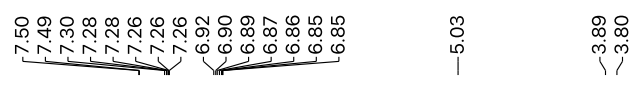<smiles>COc1cccc(C(C#N)c2ccc(OC)c(Br)c2)c1</smiles>
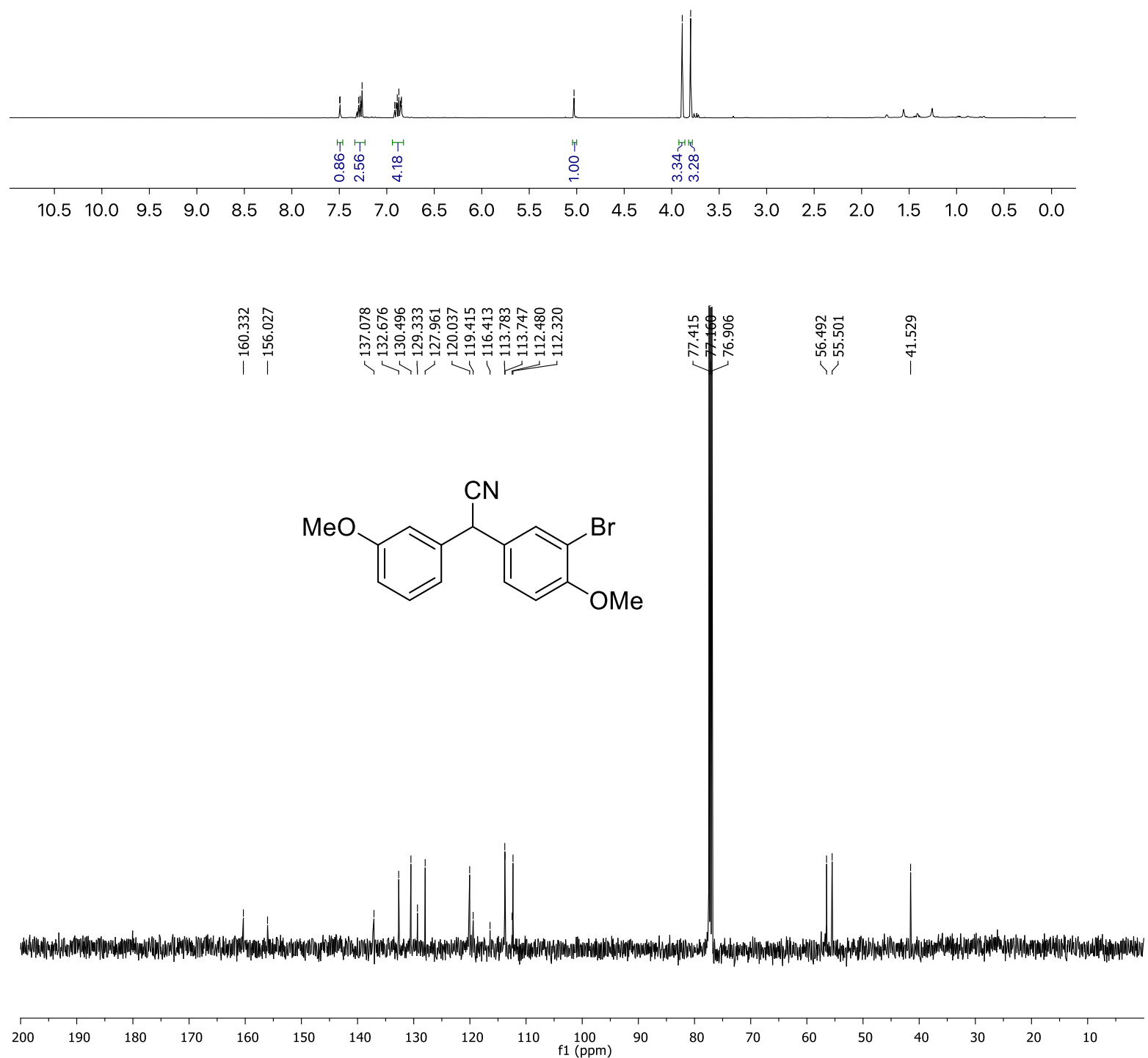


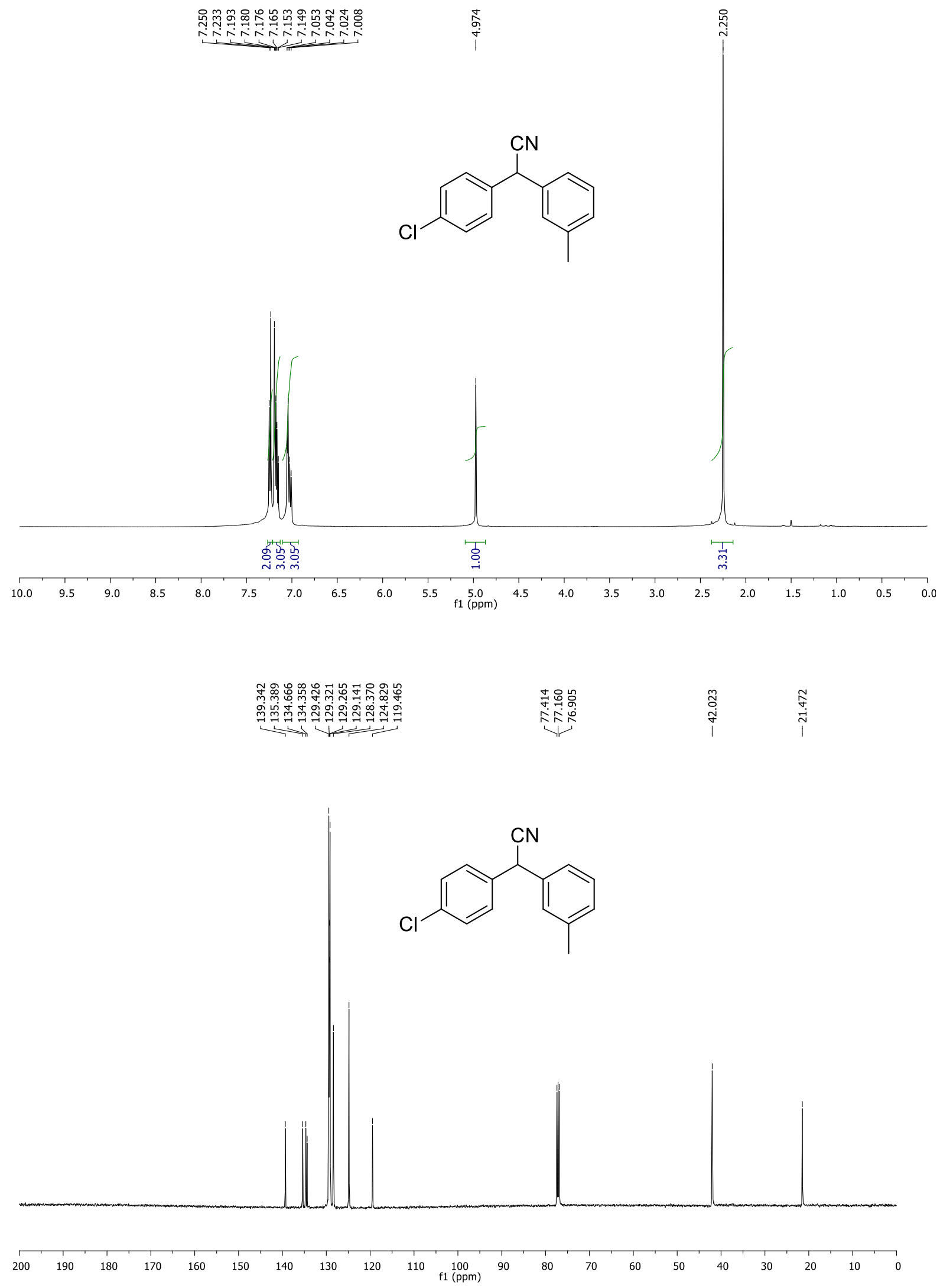




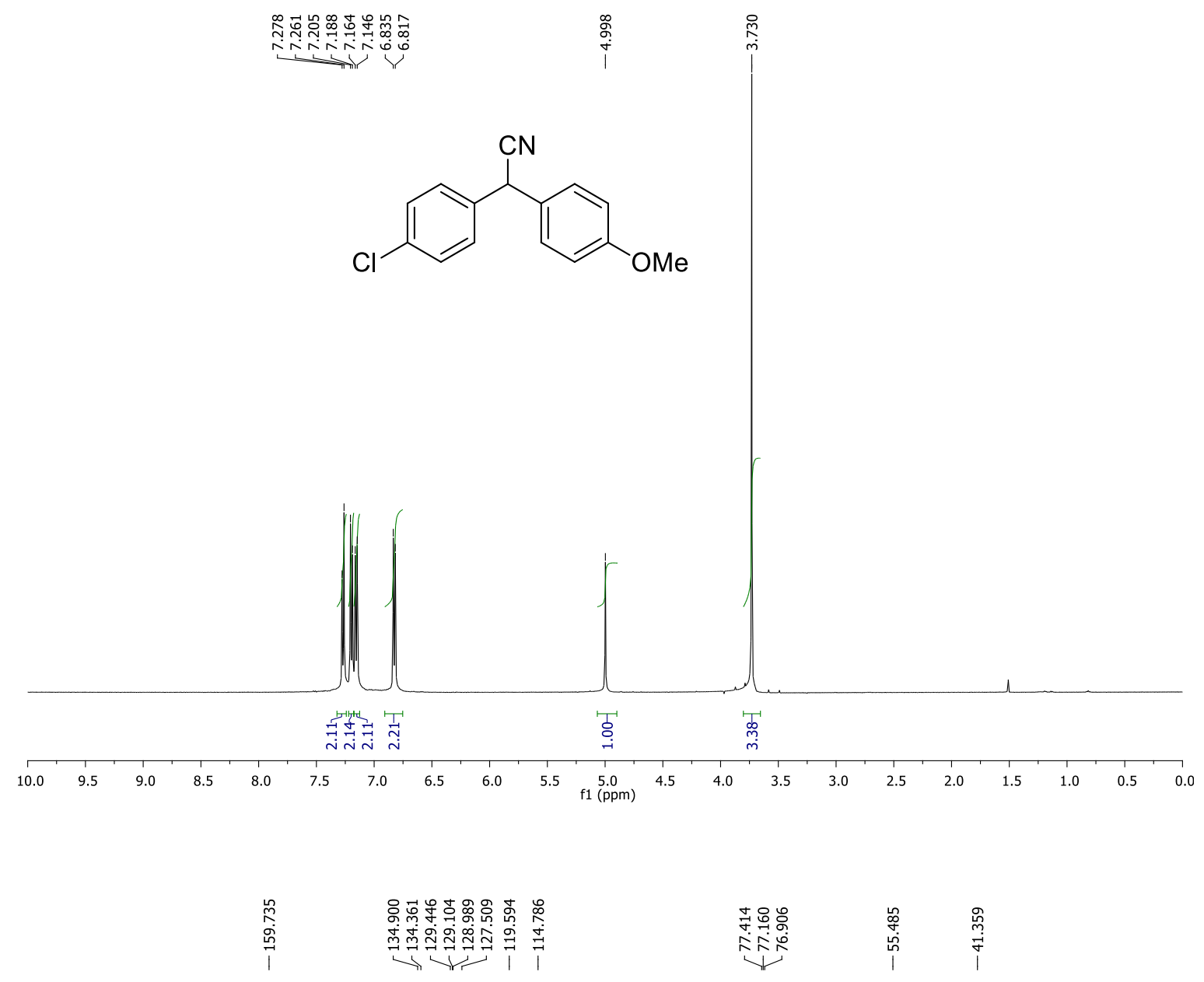<smiles>COc1ccc(C(C#N)c2ccc(Cl)cc2)cc1</smiles>
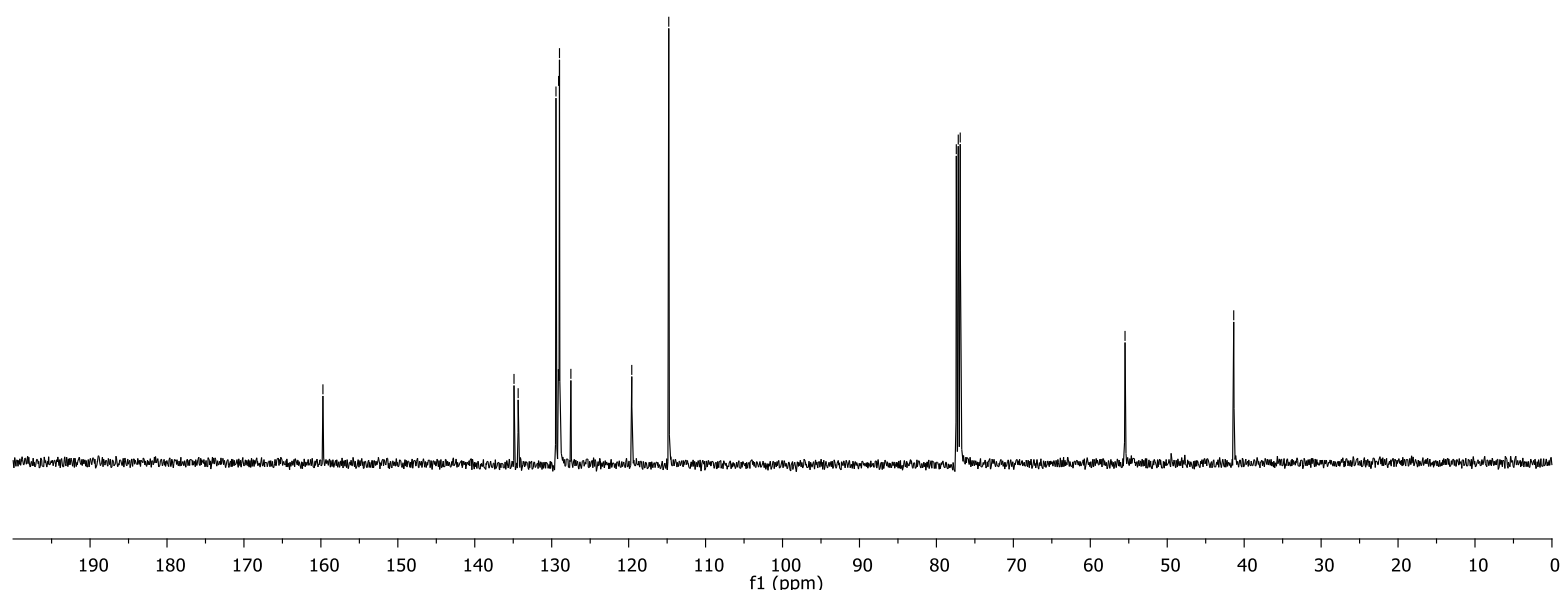

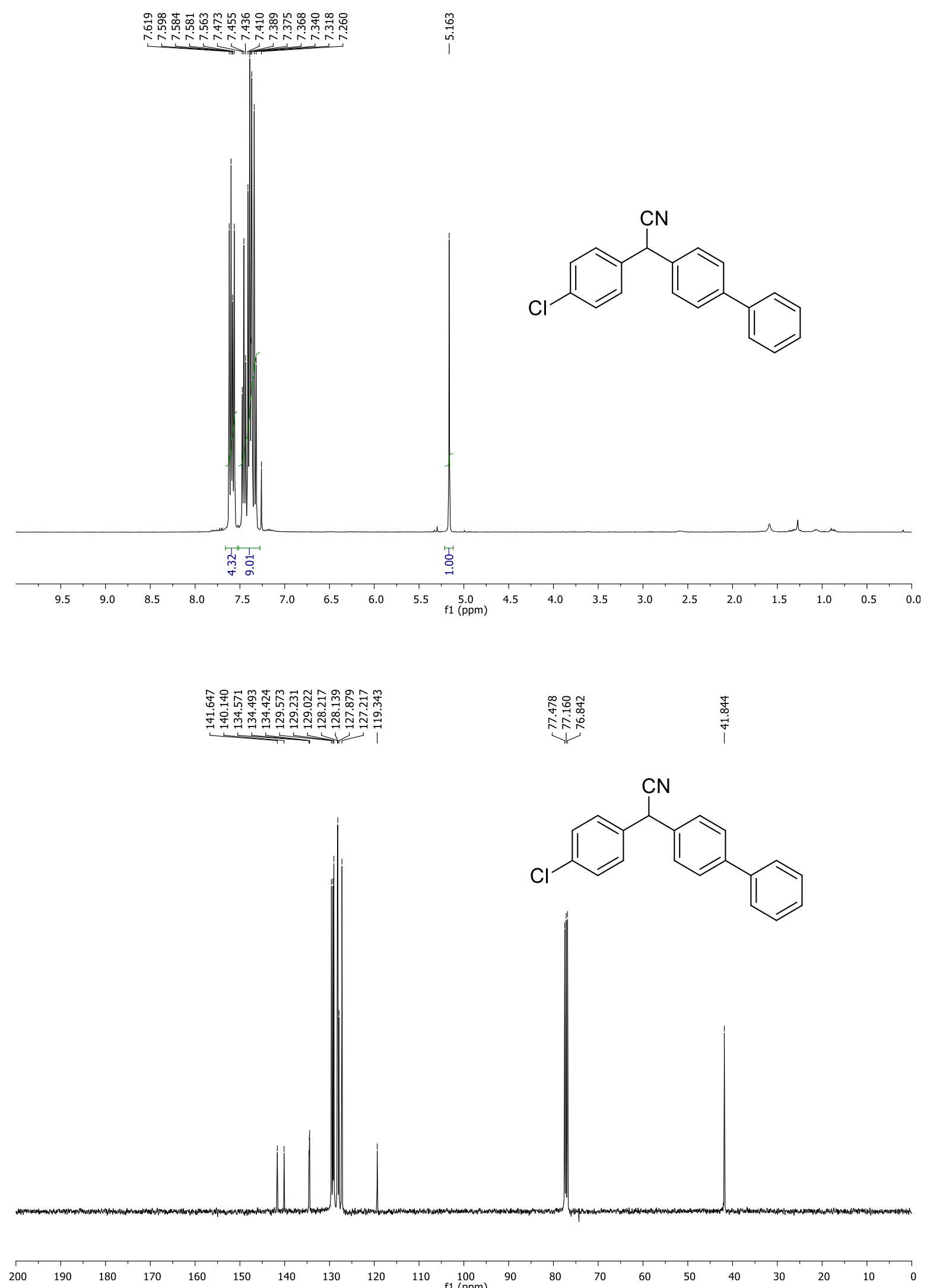

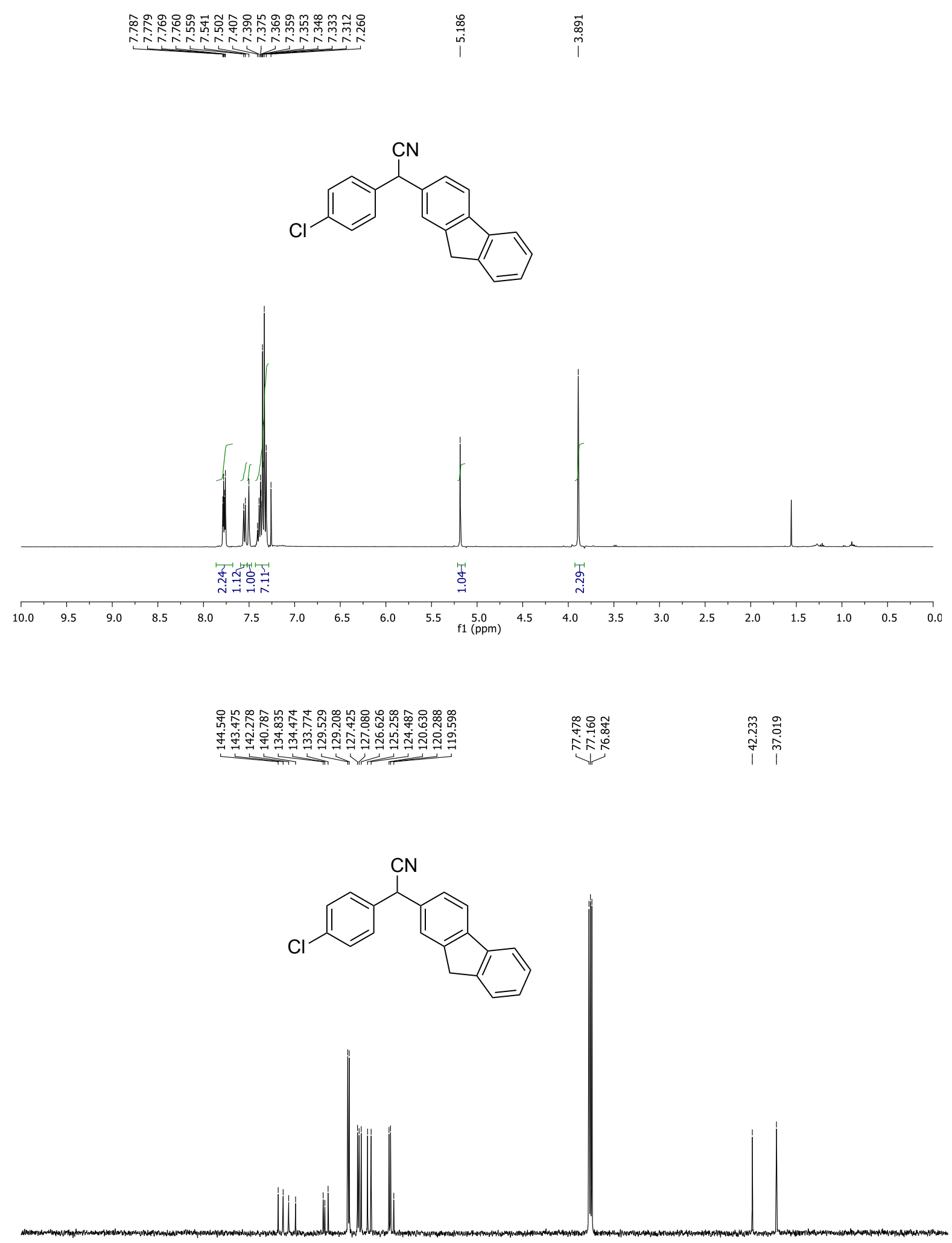

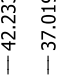

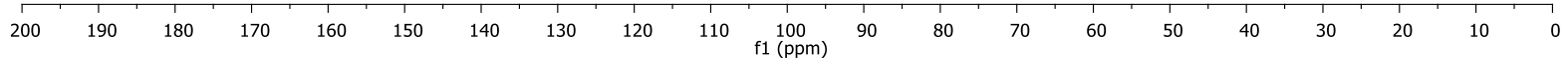



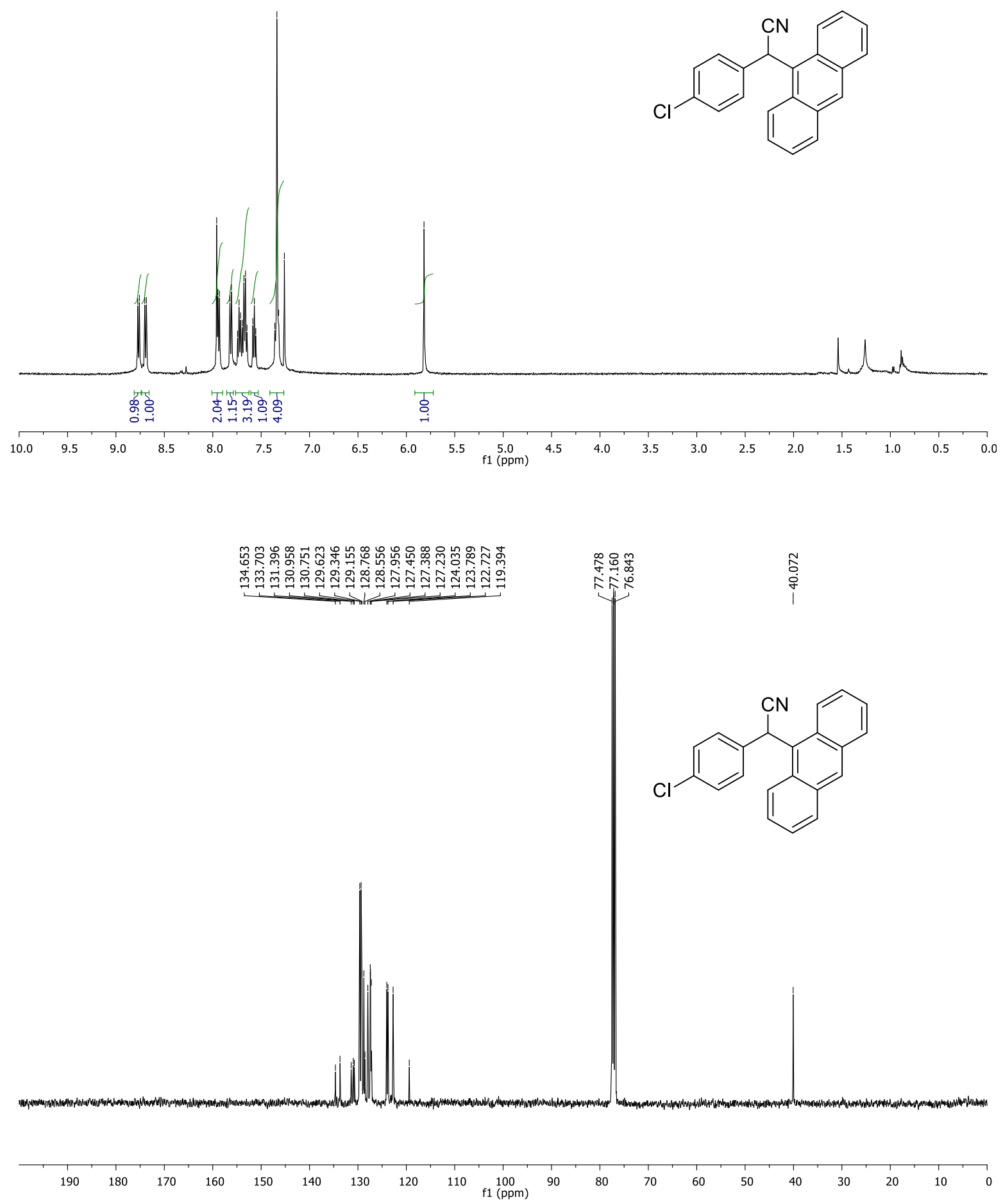

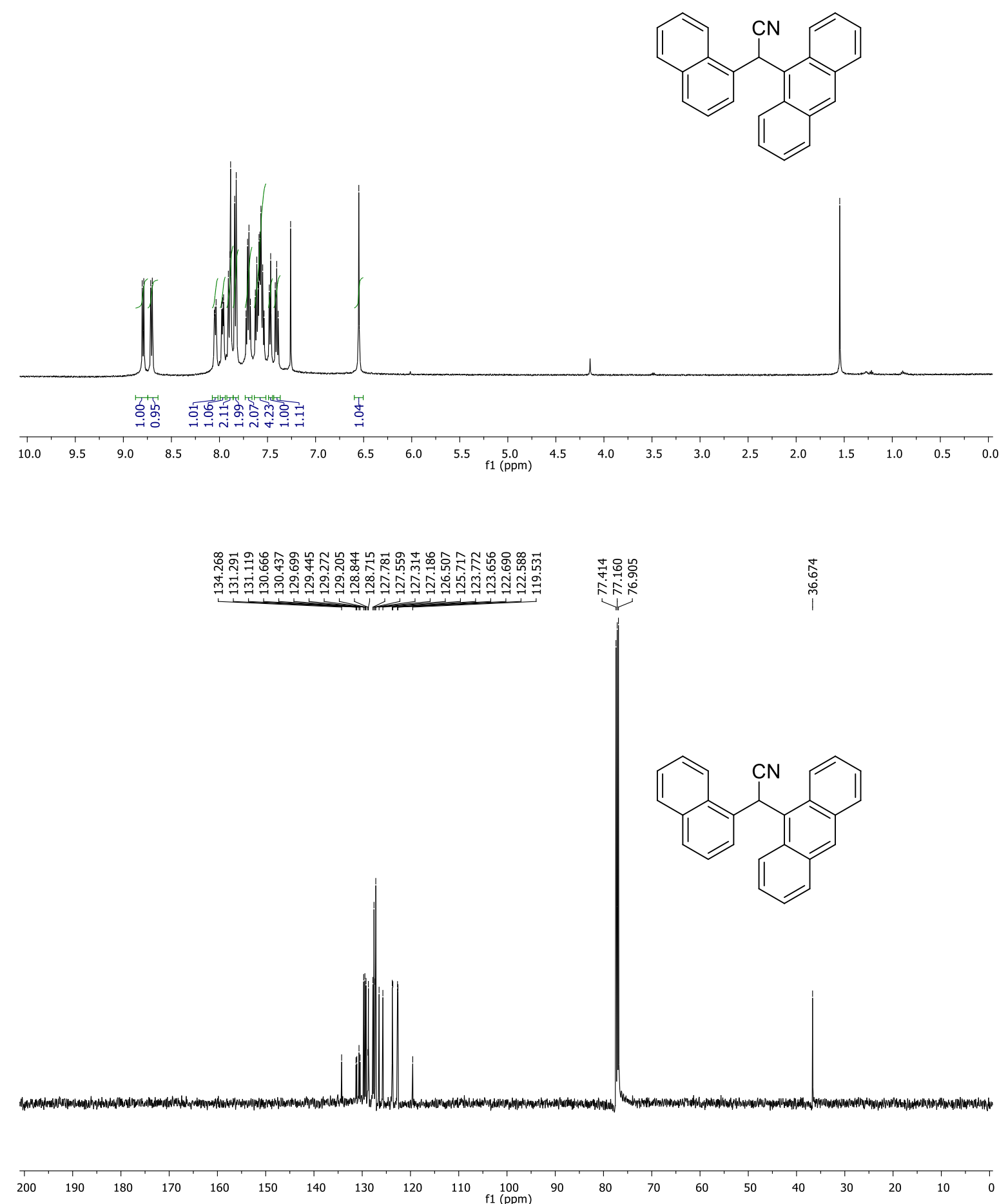

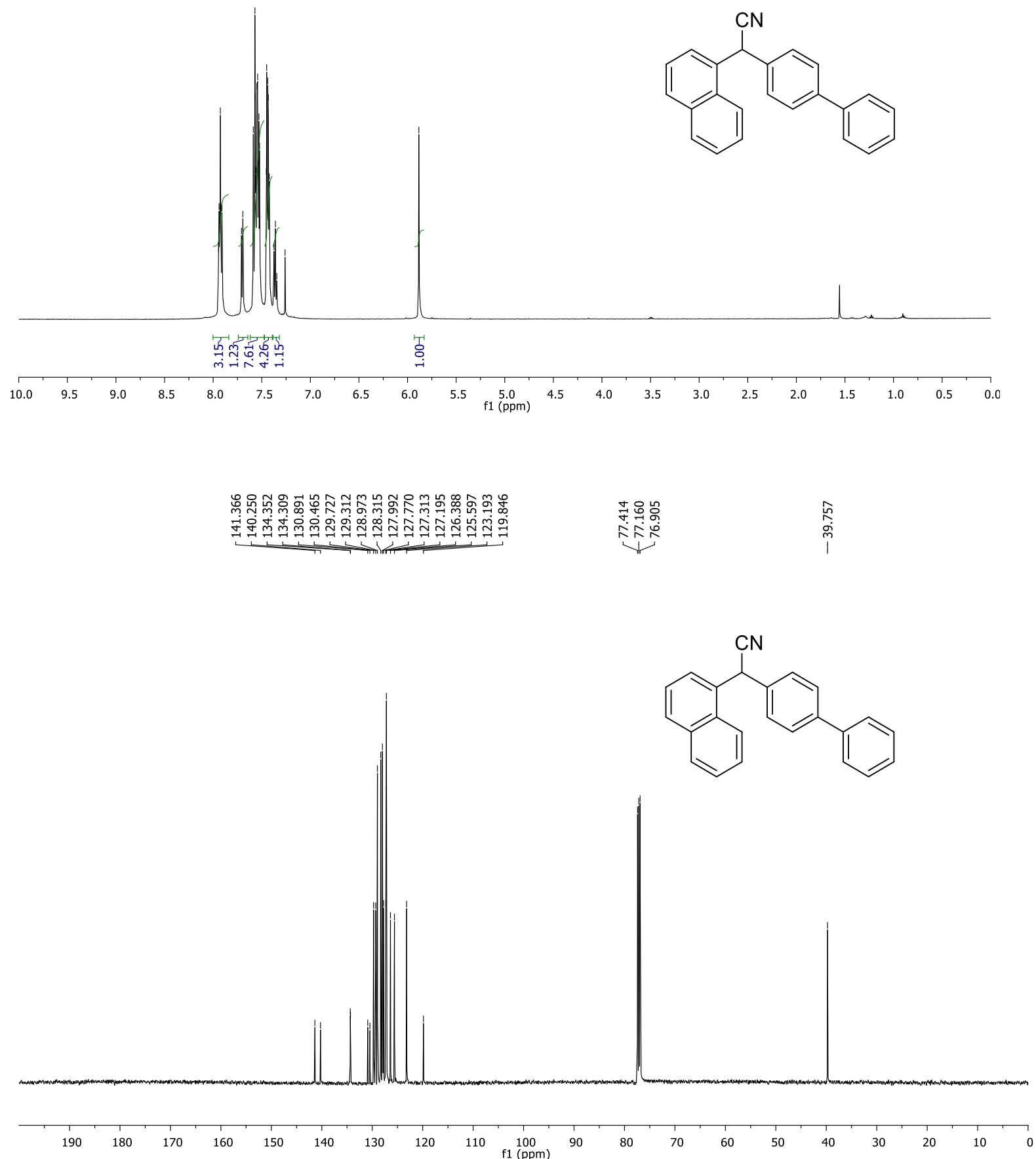


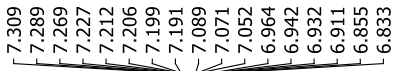

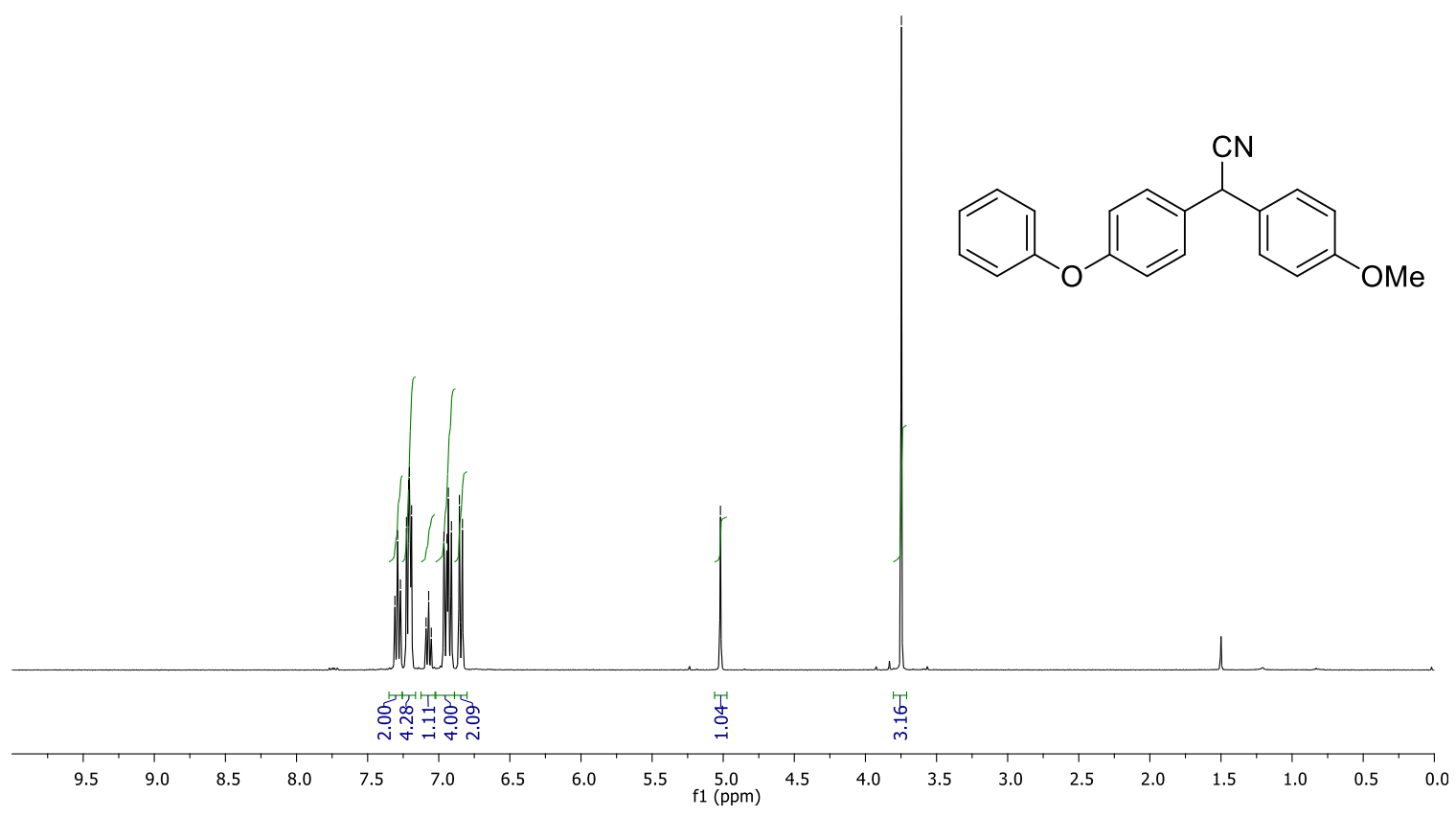

S63 


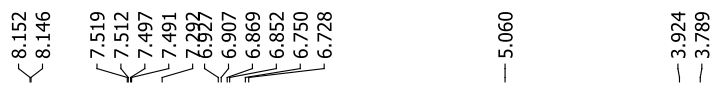

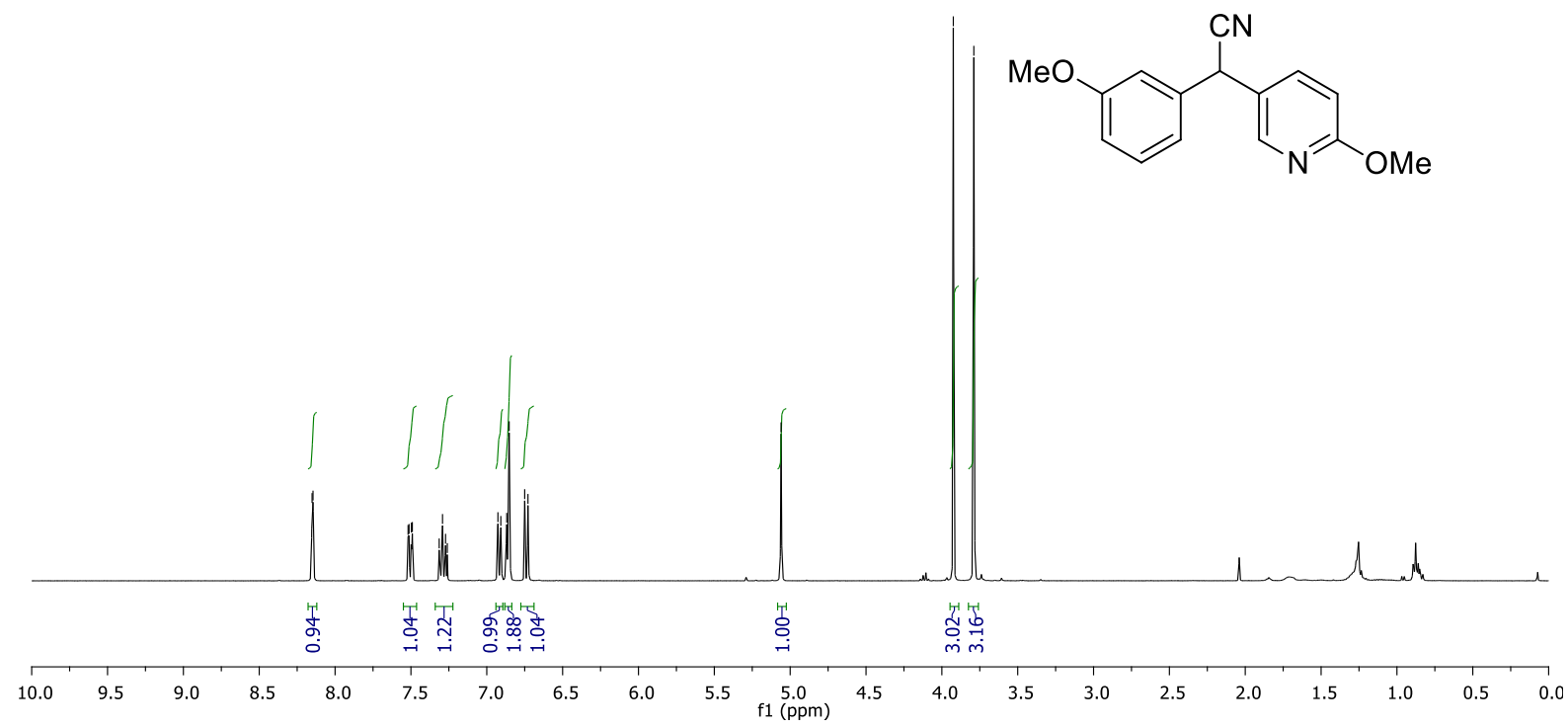

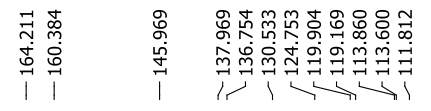

年
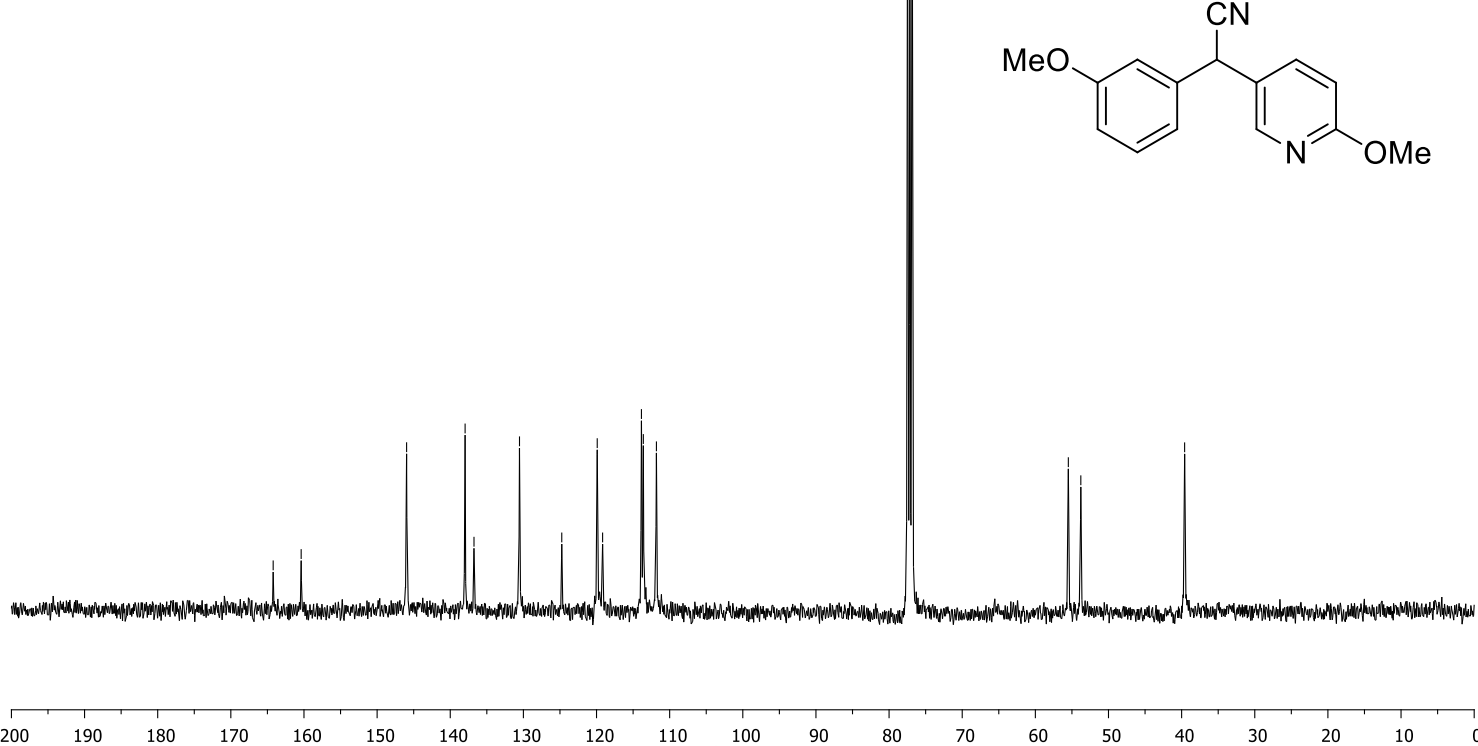

110

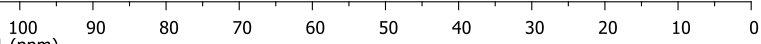



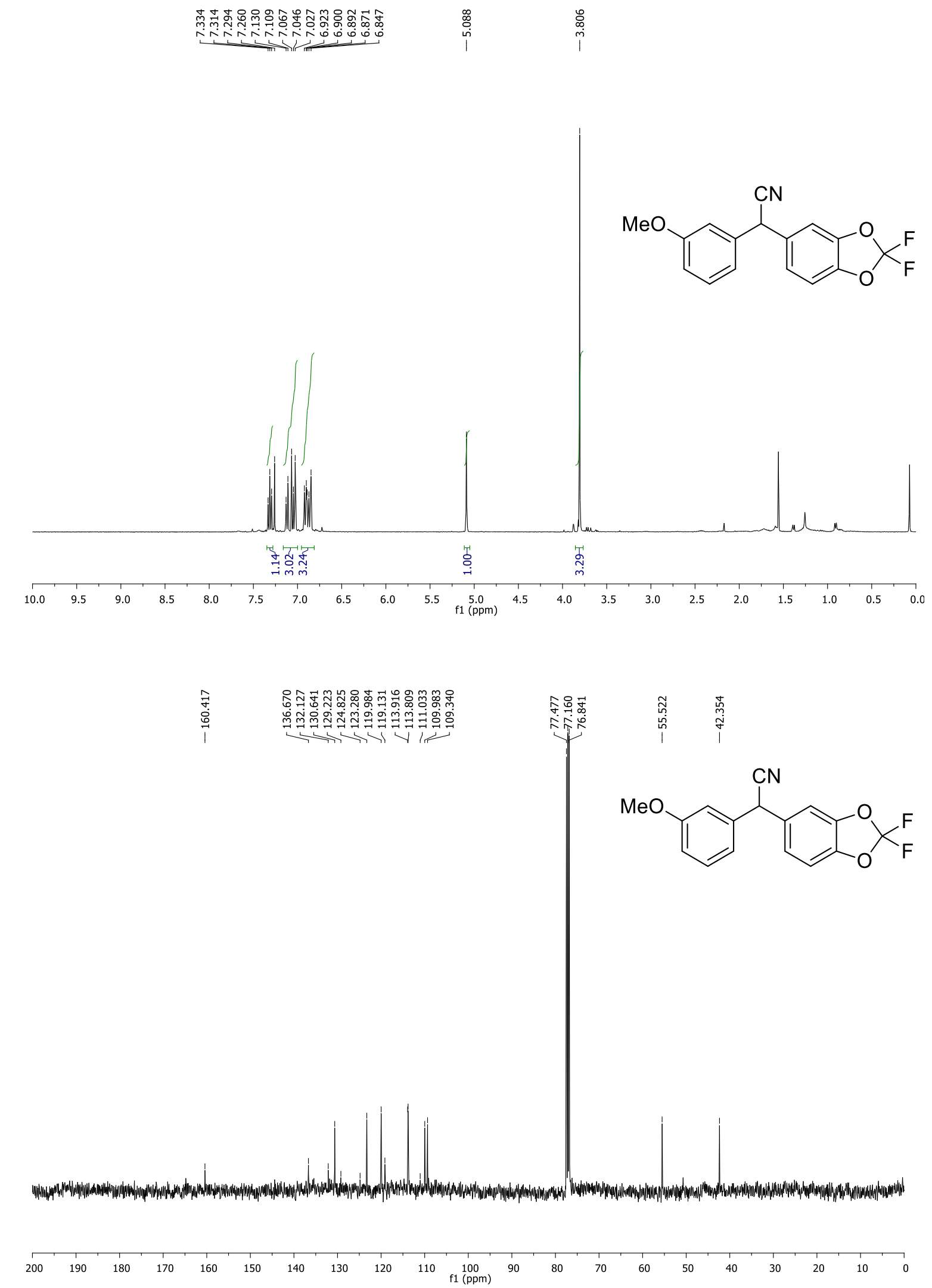


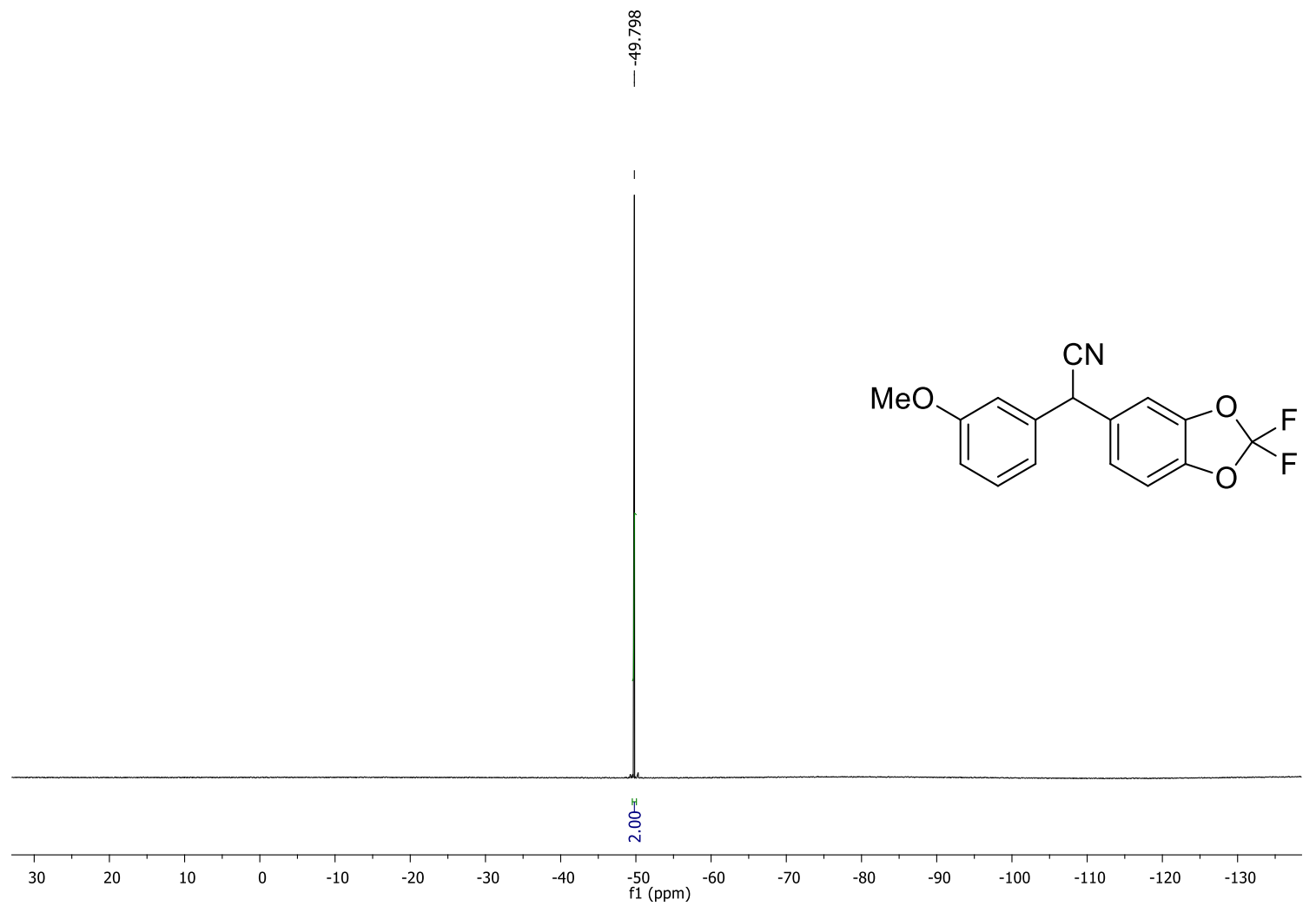




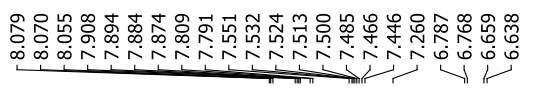

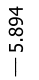

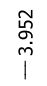
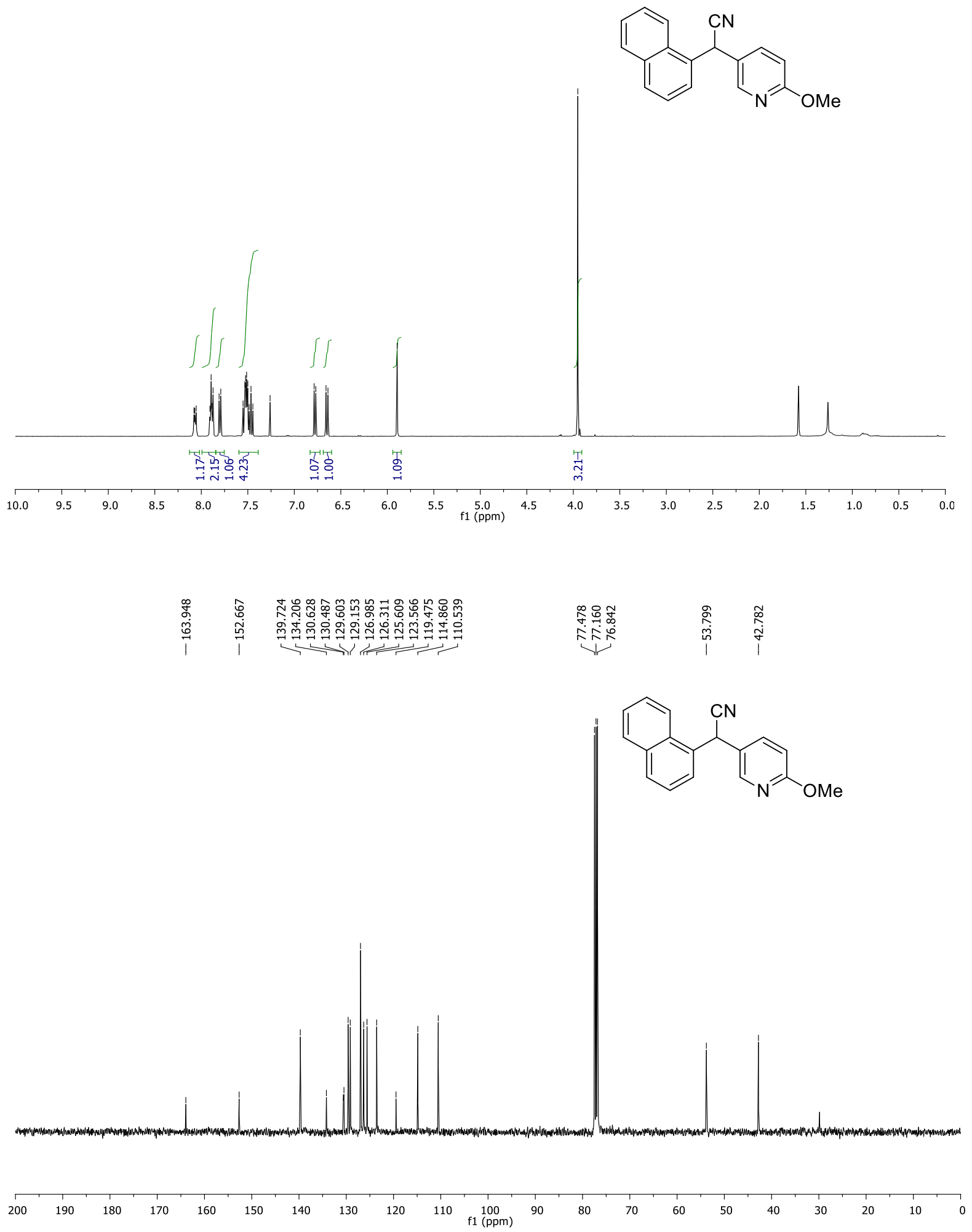

S67 

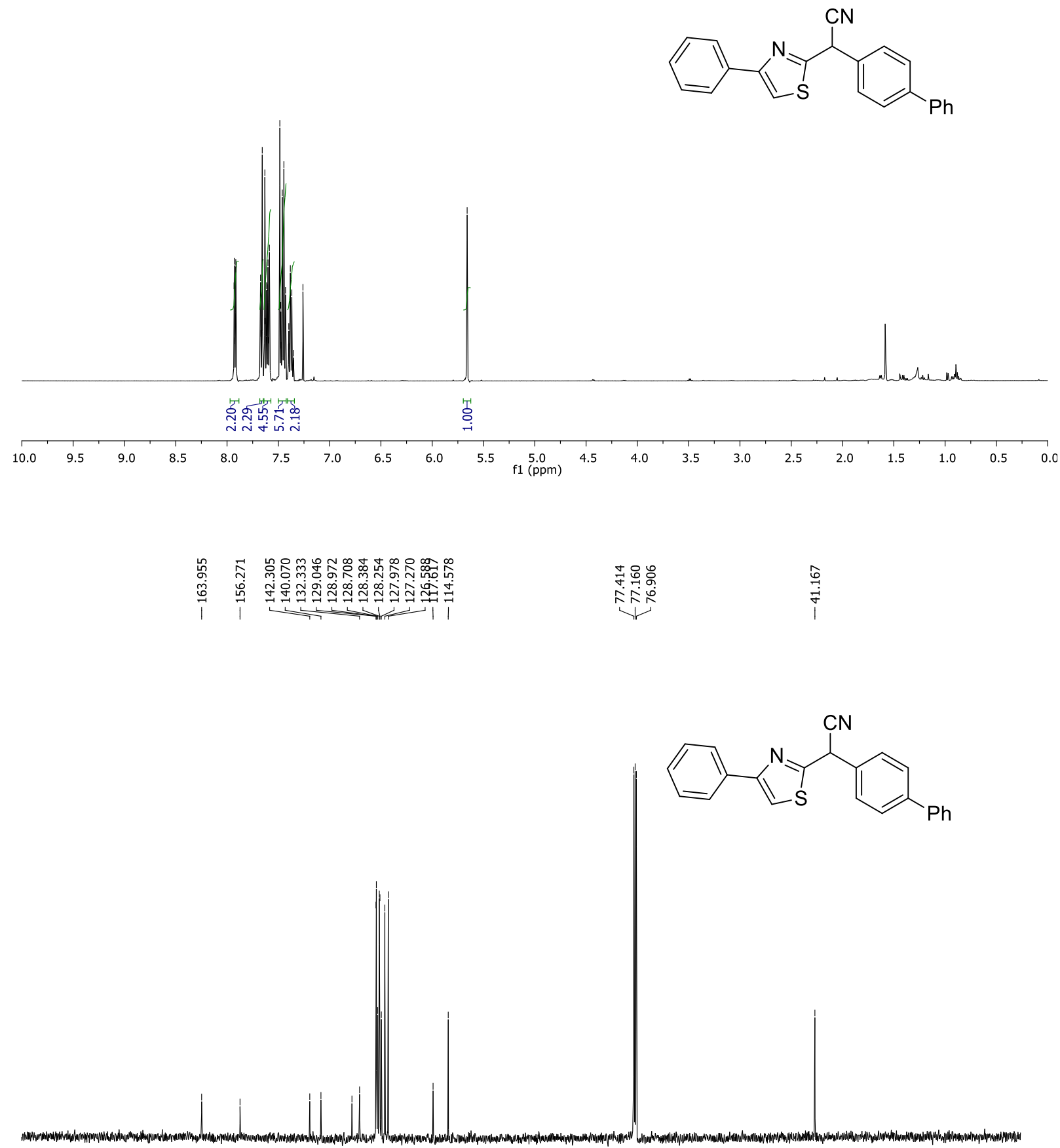

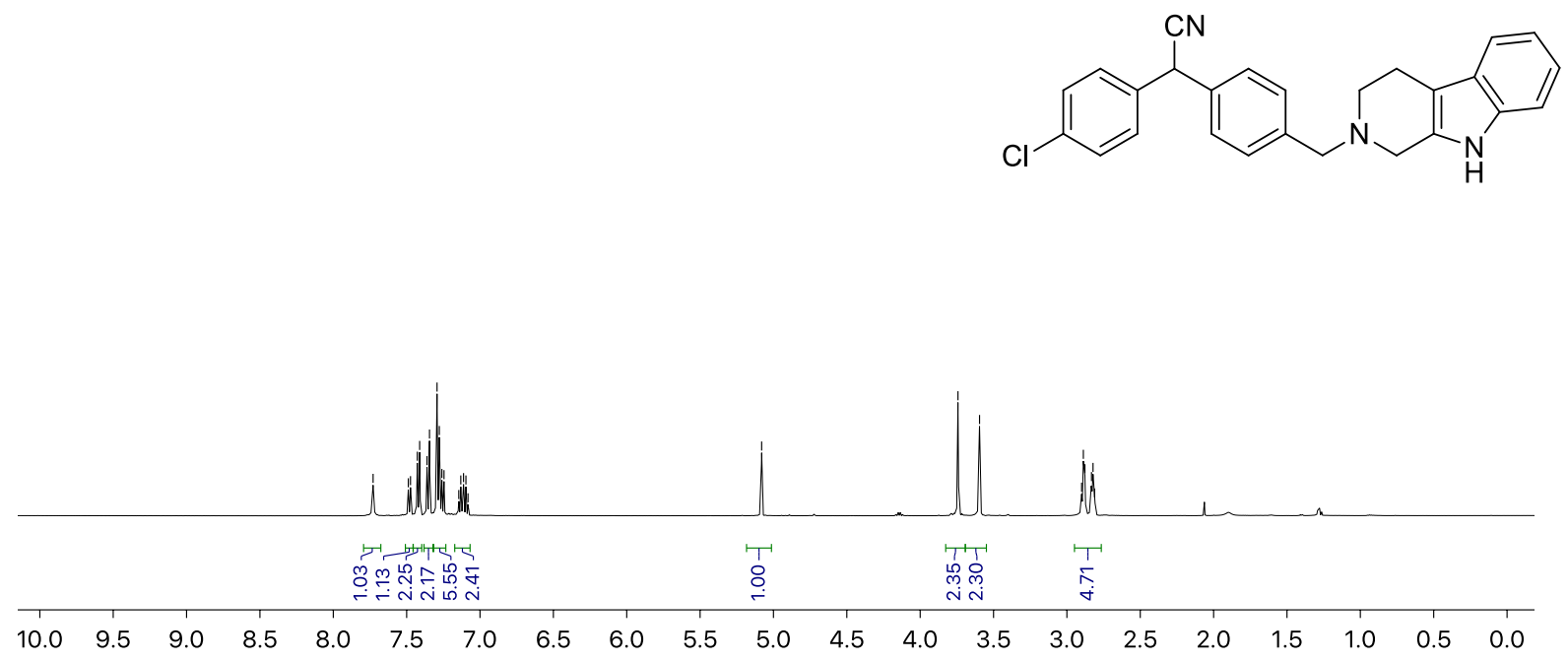

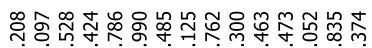

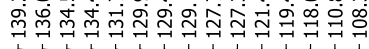

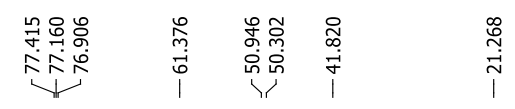

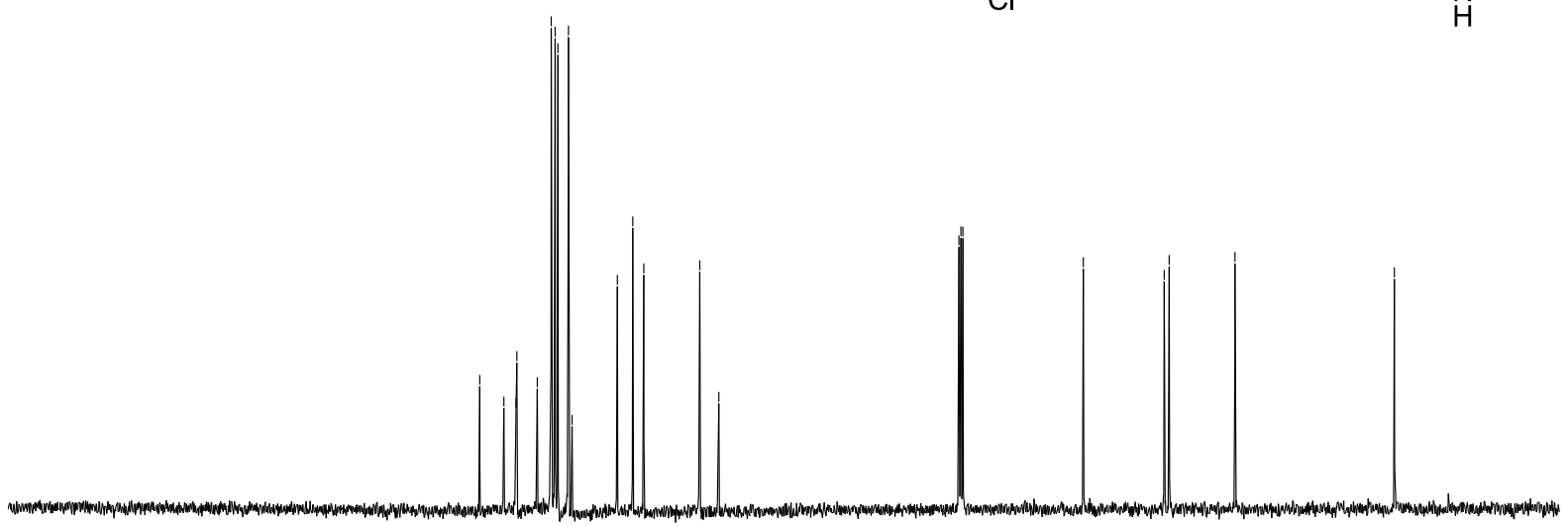<smiles>N#CC(c1ccc(Cl)cc1)c1ccc(CN2CCc3c([nH]c4ccccc34)C2)cc1</smiles>

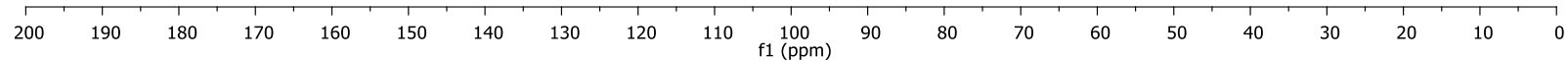




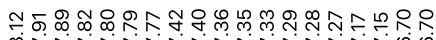

†্ণ
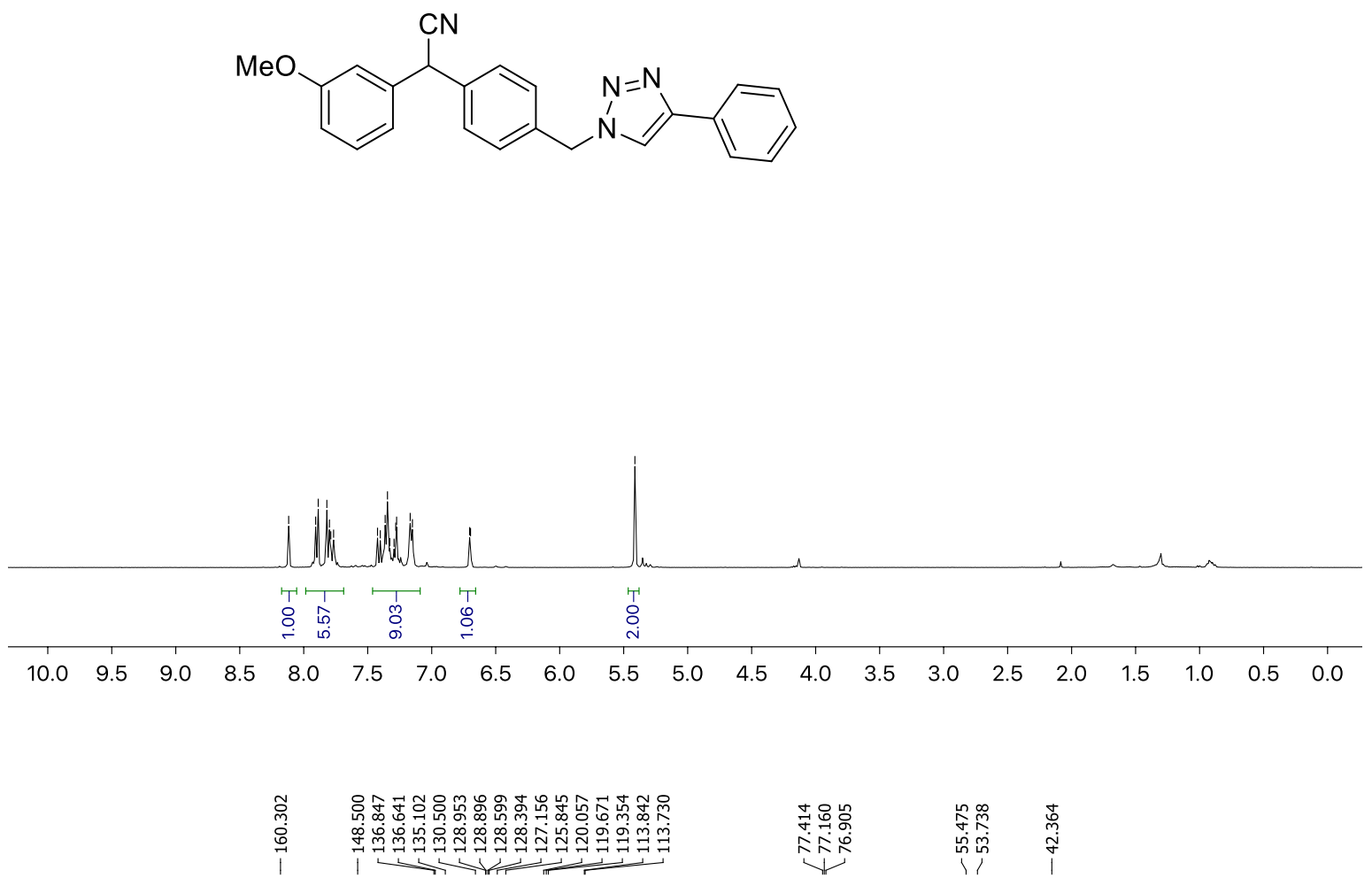

匀

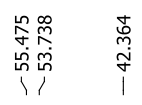

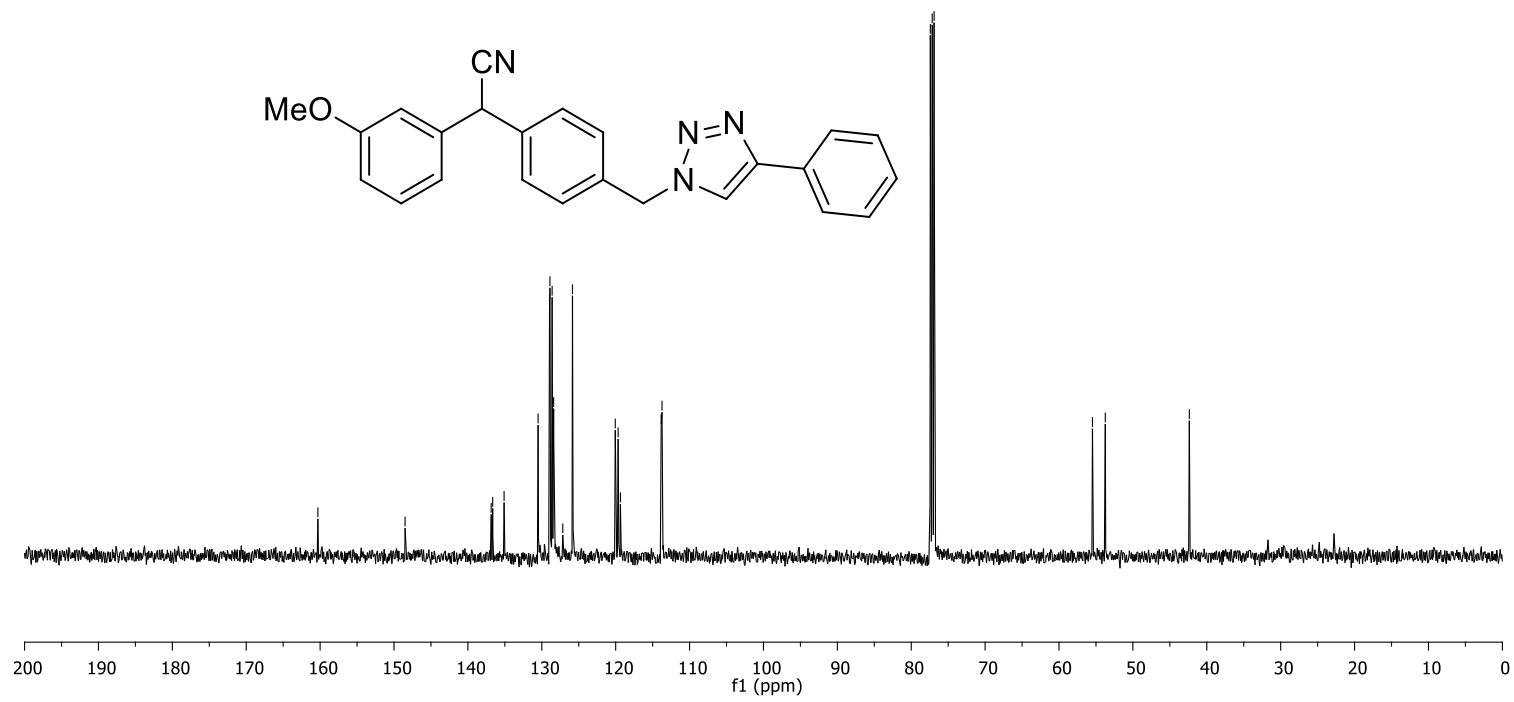

S70 

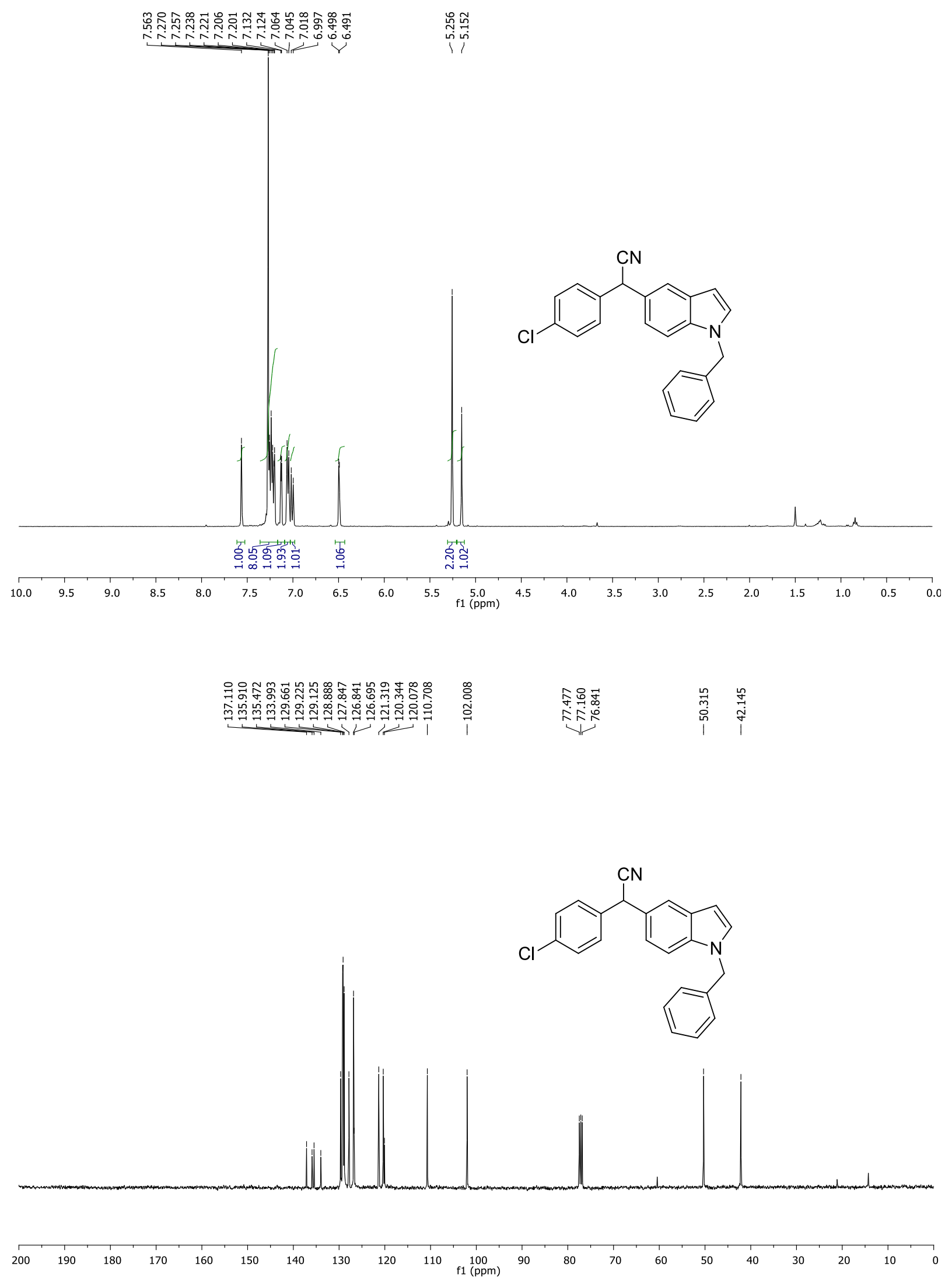
<smiles>CC(C)CCCC(C)C1CCC2C3CC=C4CC(n5cc(-c6ccc(C(C#N)c7ccc(Cl)cc7)cc6)nn5)CCC4(C)C3CCC12C</smiles>
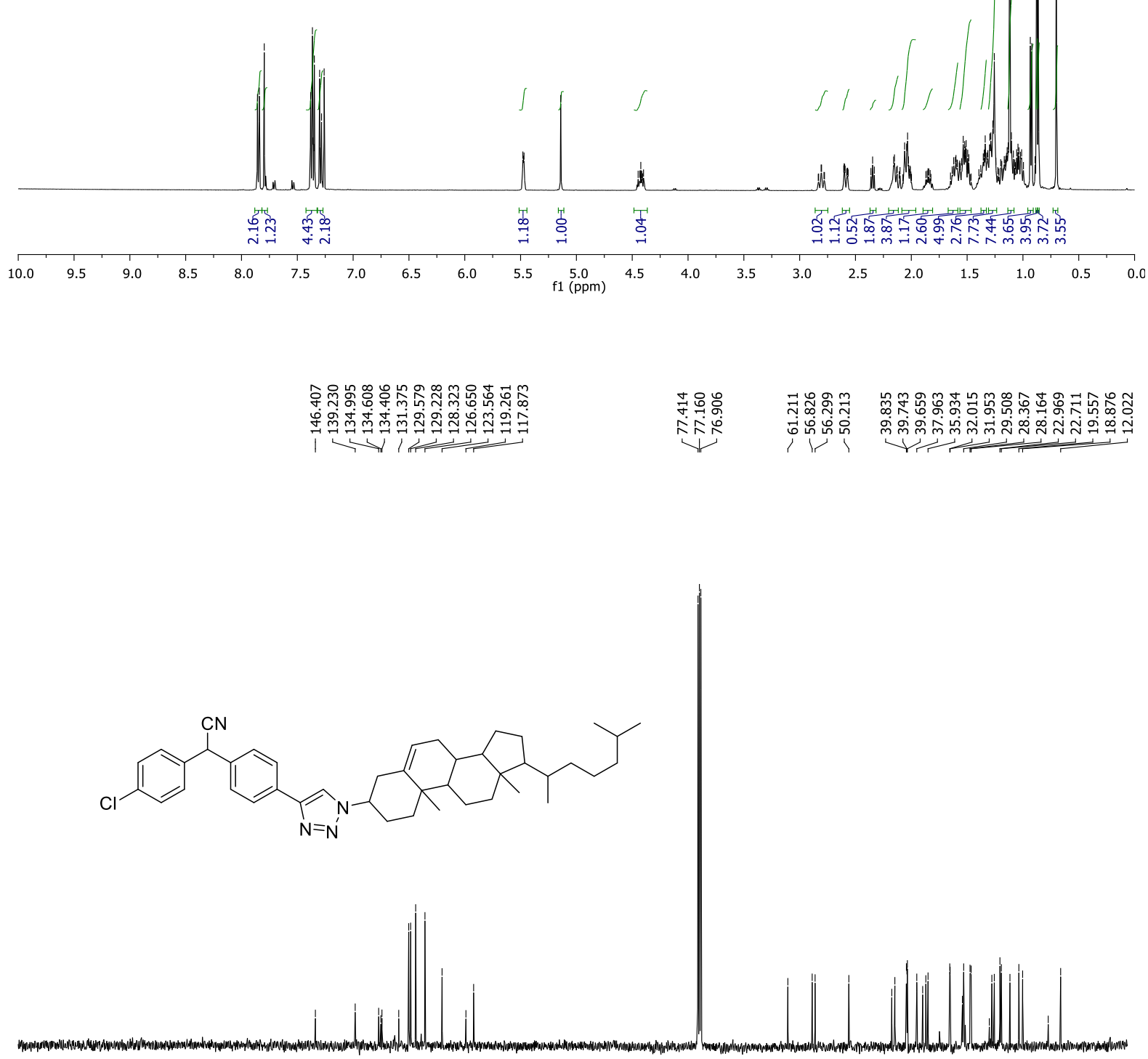$$
200
$$
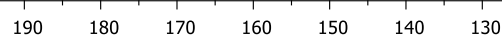

120
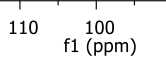

$80 \quad 70$

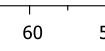

50

$40 \quad 30$

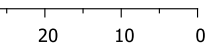



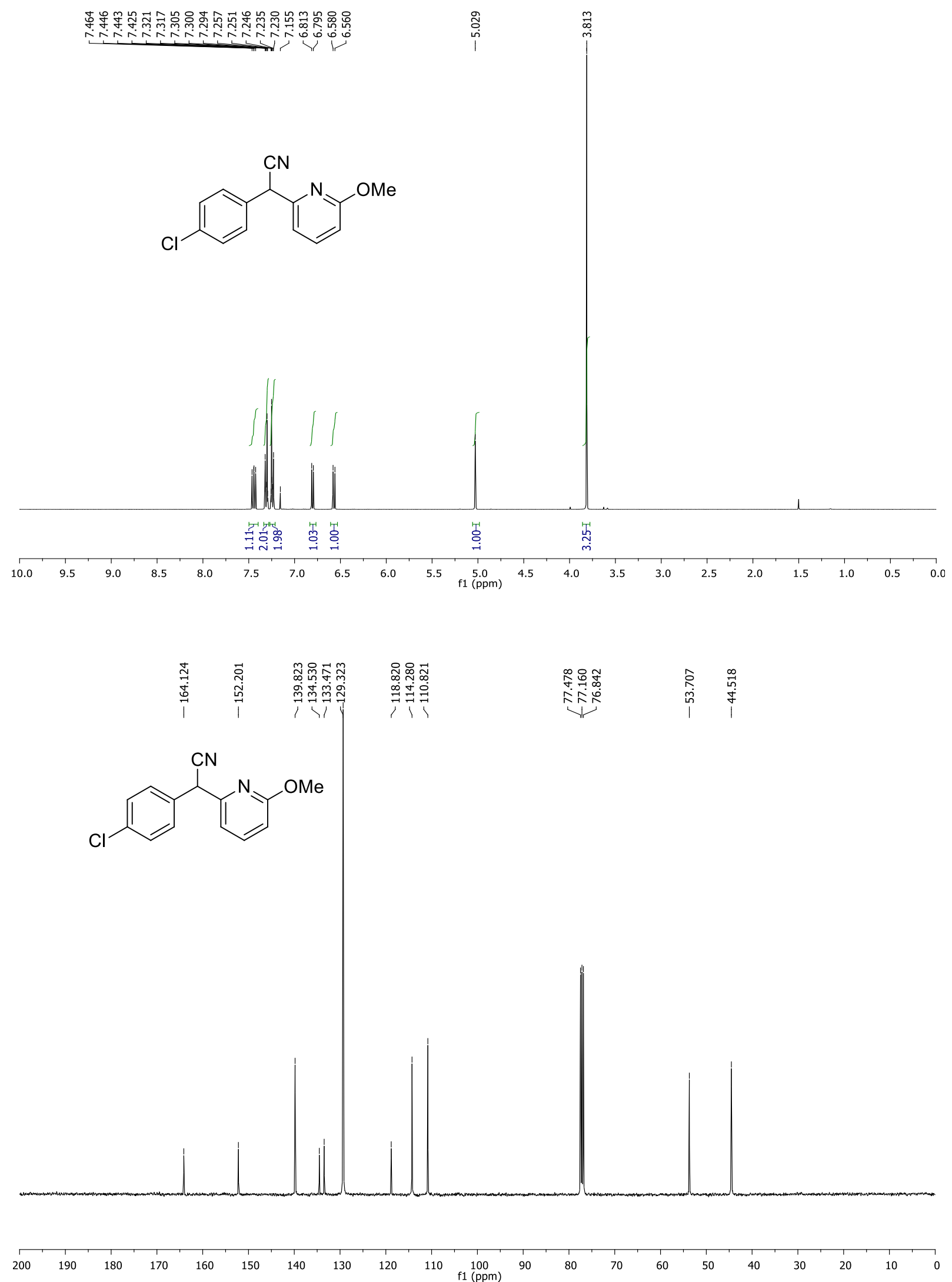
<smiles>COc1ccc(C(C#N)c2ccc(-c3cccc4ccccc34)cc2)cn1</smiles>
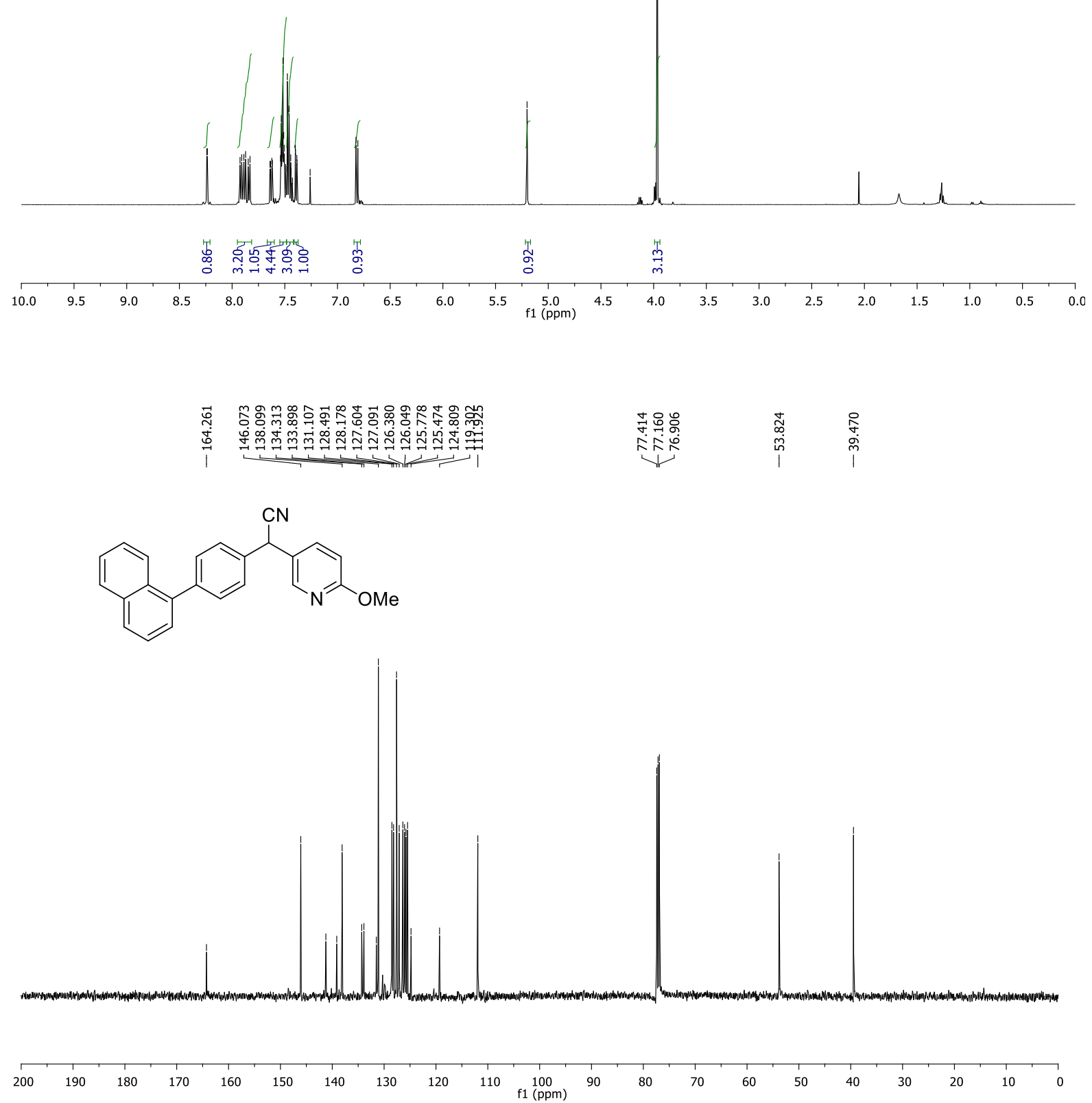


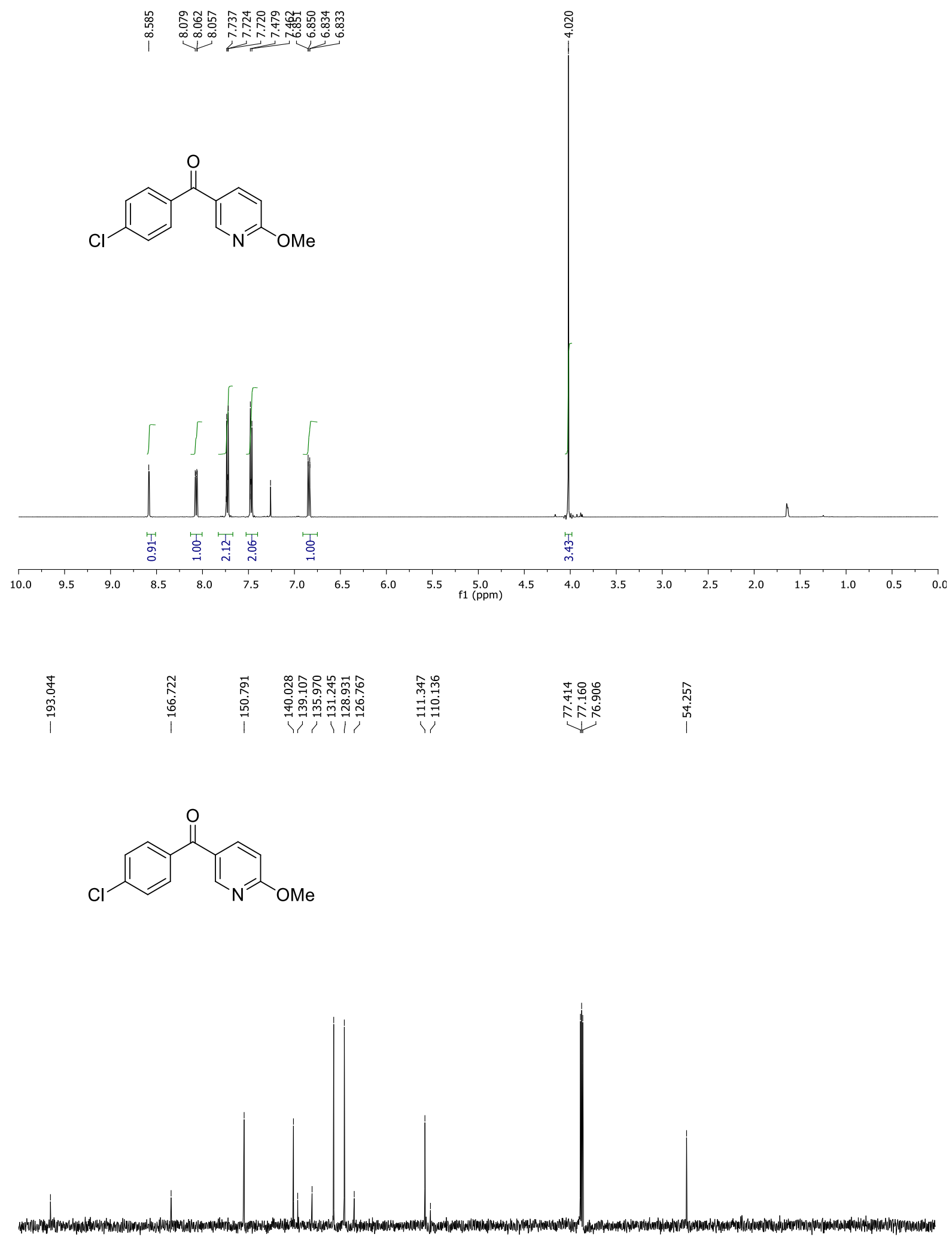

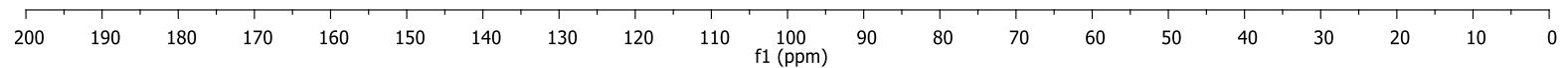


<smiles>O=C(c1ccc(Cl)cc1)c1ccc2c(ccn2Cc2ccccc2)c1</smiles>
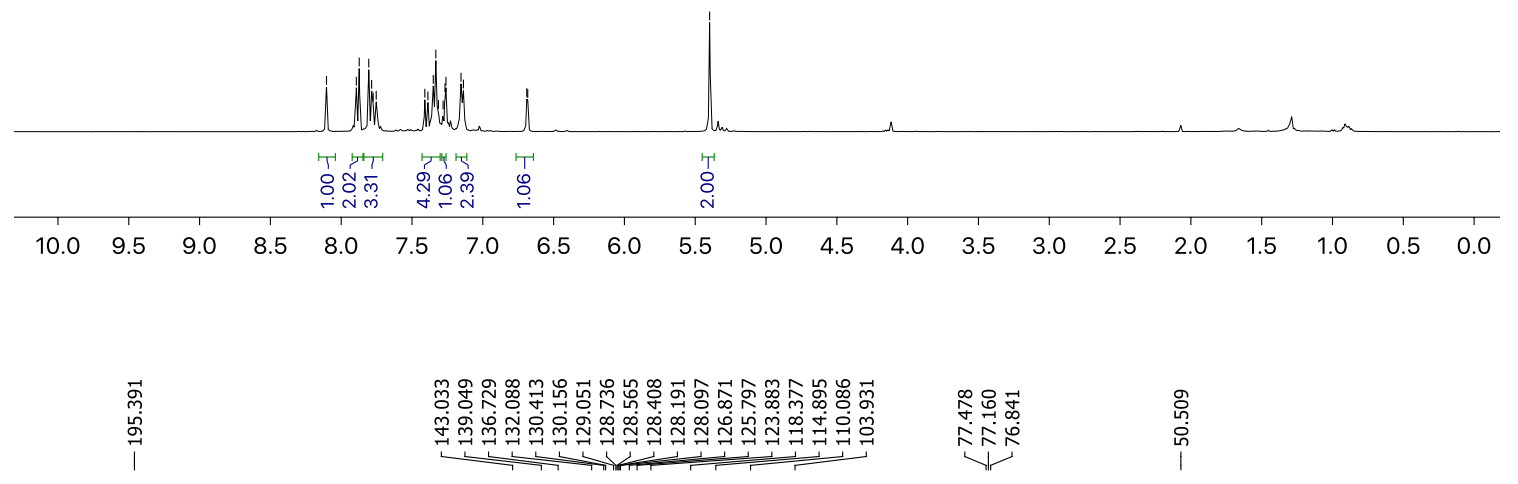<smiles>O=C(c1ccc(Cl)cc1)c1ccc2c(ccn2Cc2ccccc2)c1</smiles>
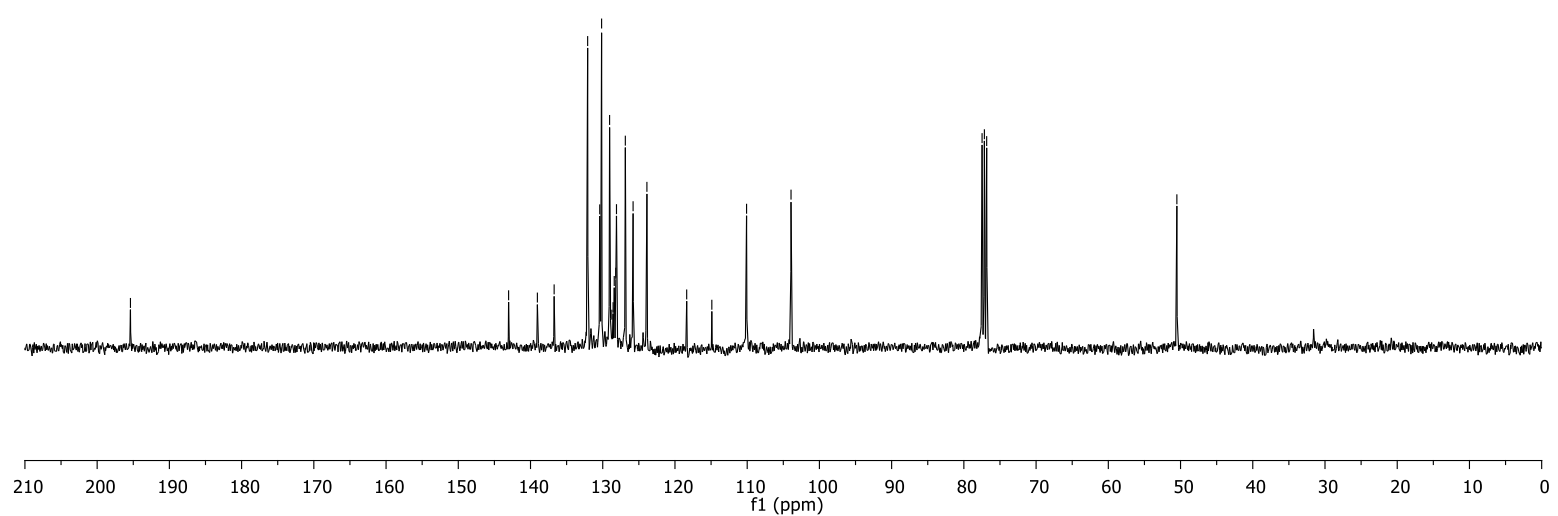
<smiles>Cn1ccc2cc(C(=O)c3ccc(Cl)cc3)ccc21</smiles><smiles>O=C(c1ccc(Cl)cc1)c1ccc(Cl)cc1</smiles>

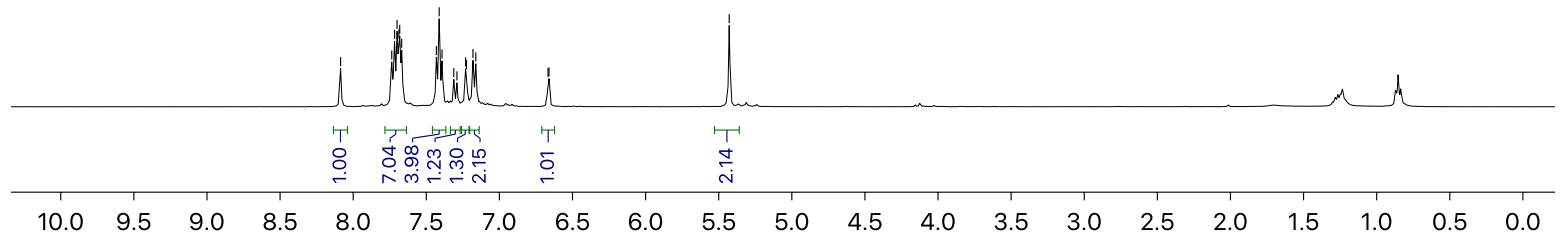

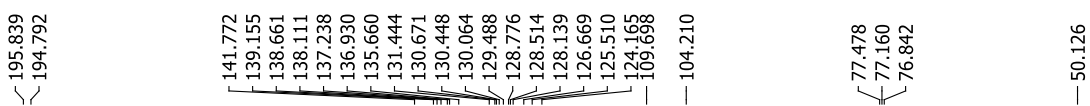
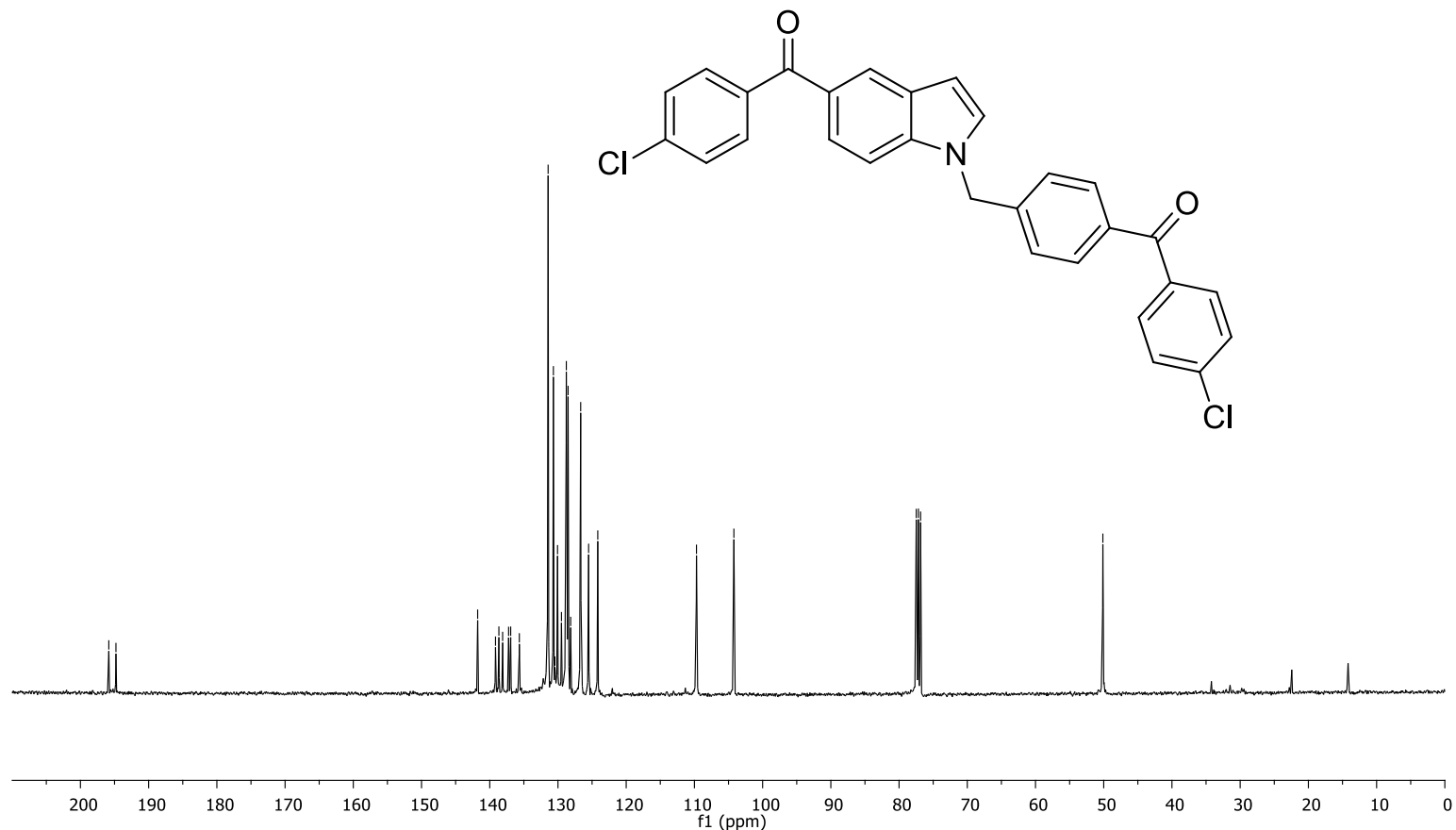

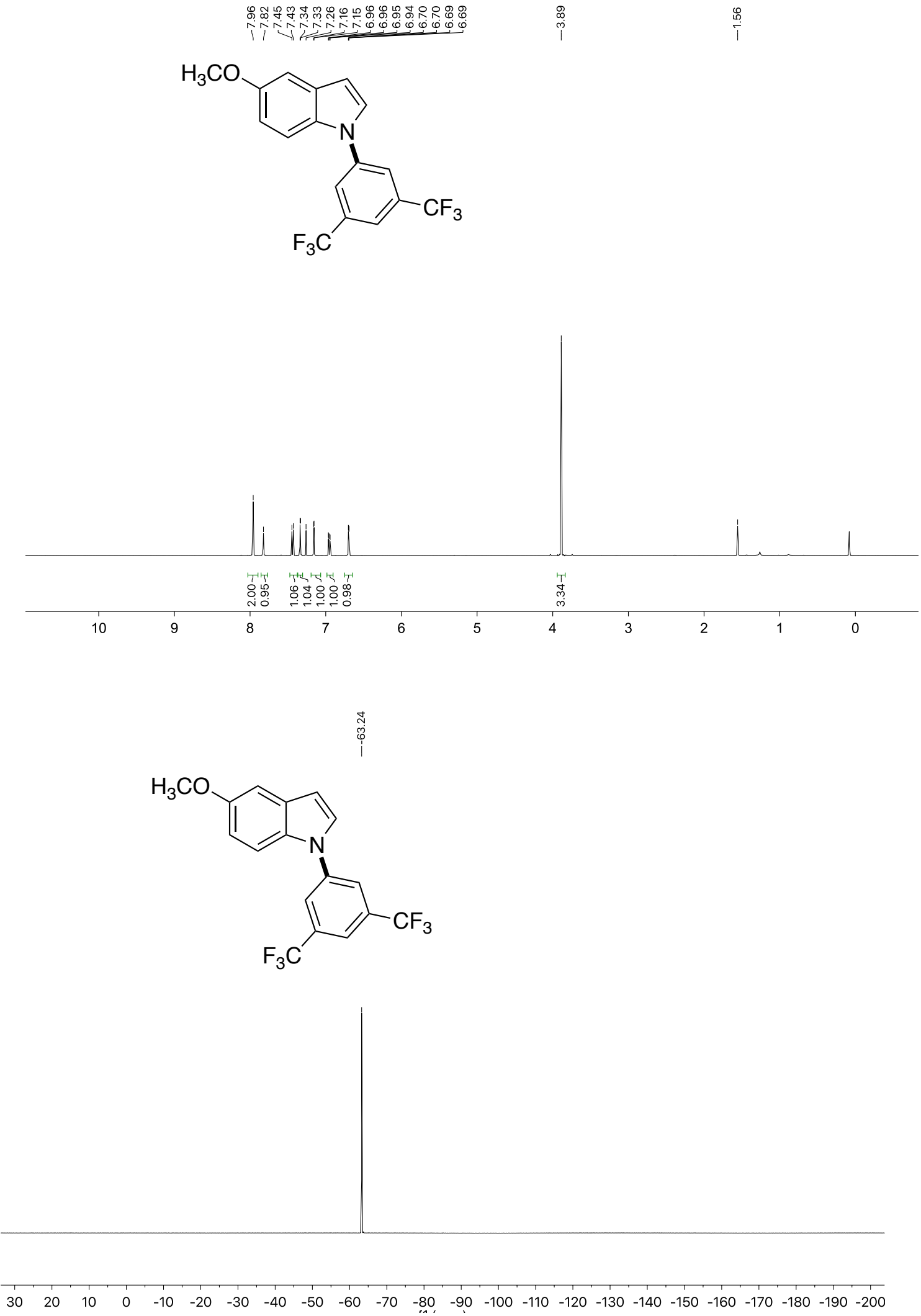